\title{
CARACterização genÉTICA E MOLECULAR dE ESTREPTOCOCOS LACTICOS
}

ALDA LUIZA LOUREIRO DOS SANTOS

Tese apresentada à Escola Superior de Agricultura "Luiz de Cueiróz" da Universidade de São Paulo, para obtenção do título de DOUTOR em Agronomia - área de concentração: Genética e Melhoramento de Plantas

\author{
PIRACICABA \\ Estado de São Paulo \\ Novembro - 1985
}




\title{
Caracterização genETica e MOLECULAR de ESTREPTOCOCOS LACTICOS
}

\author{
ALDA LUIZA LOUREIRO DOS SANTOS \\ Engenheira Agrônoma \\ Instituto de Tecnologia de Alimentos
}

Orientador: Dr. João Lücio de Azevedo

Tese apresentada à Escola Superior de Agricultura "Luiz de Queirōz" da Universidade de São Paulo, para obtenção do título de DOUTOR em Agronomia - ärea de concentração: Genētica e Melhoramento de Plantas

\author{
PIRACICABA \\ Estado de São Paulo \\ Novembro - 1985
}


A meus pais

A Pascal 
ii

A Marie-Christine, Alain, Michel Gautier, demais mem bros e bons amigos do laboratōrio do INRA de Rennes 
Agradefo a todos aqueles que contribuiram para a realização deste trabalho e, em especial:

- Ao professor Or. Joäo Lucio de Azevedo, pela orientação, confiança, estímulo e amizade.

- A Dra. Marce-Christine Chopin, pelo estágio proporcionado em seu laboratörio, pela orientação, pelo incen tive e amizade.

- Ao Dr. Je n-Louis Maubois, Diretor do Laboratoire de Recherches de Technologie Laitière - INRA, pelo convite e facilidades concedidas para a realização de estáģio, assim como deste trabalho, além da grande amizade e apoio nos momentos dificeis.

- Ao Or. Alain Chopin, pelos conhecimentos trans mitidos, colaboração e amizade.

- A amiga Monique veaux, pela colaboração, companheirismo e as valiosas "dicas" de francês.

- As Dr. Nauto Faber de Freitas leitão, pela revisão dos originais.

- Ao Instituto de Tecnologia de Alimentos (ITAL), na pessoa do seu Diretor Dr. Rodrigo otálo Teixeira Neto, pelas facilidades concedidas. 
- A. Empresa Brasileira de Pesquisa Agropecuäria (EMBRAPA), pela oportunidade de realização de estägio no iNRA, França.

- Ao Conselho Nacional de Desenvolvimento Científico e Tecnológico (CNPq), pela bolsa de pesquisa concedida.

- A Seção de Leite e Derivados do ITAL, à técnica de laboratório Izildinha Moreno e demais amigos que lá trabalinam, peì colaboração.

- Aos funcionārios da Biblioteca do ITAL é, em especial, a Antonieta Matos, pelo auxílio prestado.

- A Vera Maria Barbosa Luporini e Cristina Helena R. Comodo Gonçalves, pela revisão ortogrä́ica.

- A Dora Regina Duarte Chiaramonte, pela confecção dos grä́ficos.

- As amigas Graciana da Penha Rossato Sancho, pe la datilografia do manuscrito e Carmen Silvia Barros Penteado, pela paciència e eficiència na datilografia final, feita em tempo "record".

- Ao querido amigo Michel Gautier, pela vaiorosa troca de informações, colaboração e imenso carinho em todas as horas. 
- Aos amigos Annette Rouault, Danicl Simon, Philippe Langetea e Marie-Therése Benard, pela colaboração e amizade na convivência no laboratório.

- Aos guardinhas odair Amancio Lopes e Antonio Santos Mendonça, pela colaboração na confeç̧ão das cōpias xerox.

- As estagiárias Adriana L.C. Balys e Maria Aparecida Lima, pela colaboração.

- Aos meus amigos de todos os momentos, especial mente Pascaline Garnot, Iacky Desmeulles, Stella Vieco, Michel Mahaut, Iean Narie Launent, Daniel Nolle, Paul Ducruet, Christian Corre, Christiane Hulin, Anne-Marie Renoird e Gaby, que com seu apoio me ajudaram a "seguir em frente". 
1. RESUMO

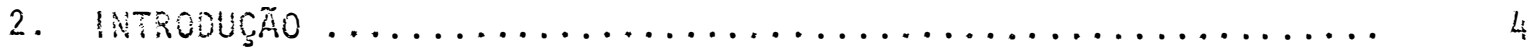

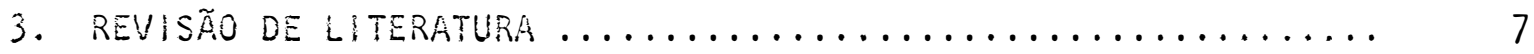

3.1. Bactërias läcticas ....................... 7

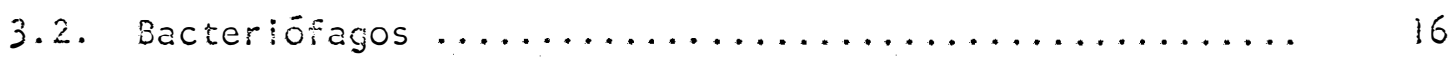

3.3. Sistemas de Restrição/Miodificação .............. 28

3.4. Controle de bacteriofagos .................. 33

3.5. Plasmidios e Melhoramento Genético ............... 43

4. MATERIAL E METODOS .............................. 51

4.1. Microrganismos utllizados $\ldots \ldots \ldots \ldots \ldots \ldots \ldots \ldots \ldots \ldots \ldots \ldots$

4.2. Plasmídios utilizados ..................... 53

4.3. Bacteriófagos utilizados .................. 54

4.4. Esterilização e nümero de repetições ................ 54

4.5. Meios de cultura e soluções utillizadas ............. 55

4.5 .1 . Neio

4.5.2. Meio MI7

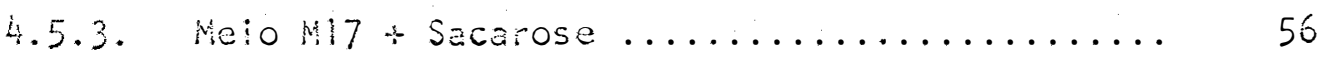

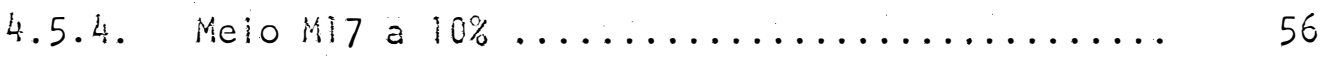

4.5.5. Meio de Luria e Bartani ................. 56

4.5.6. Meio $\mathrm{Nl7}+$ Glicose + Gi icerol ............ 57

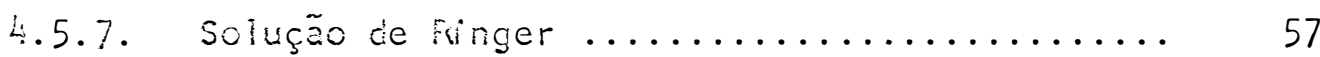

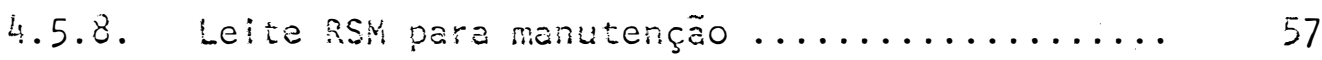

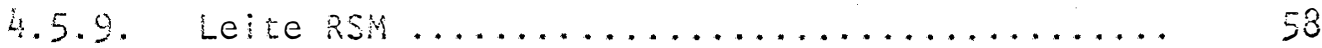

4.5.10. Tampão de lise para extração preparativa de plasmidios ....................... 58

4.5.11. Tampão de lise .................... 58

4.5.12. Tampa parall sador de lise .............. 59

4.5.13. Tampão para protoplastos ................ 59

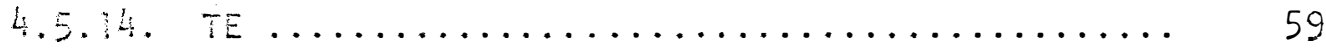


4.5.15. TE para diälise .................... 59

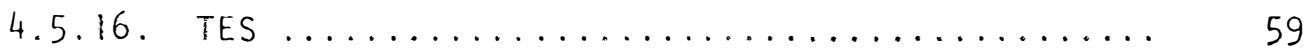

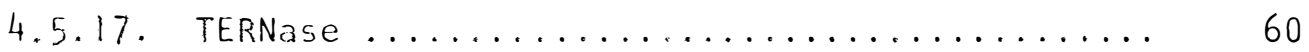

4.5.18. Tampão para extração de DNA cromossômico ..... 60

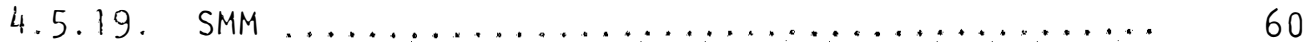

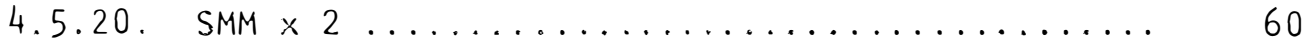

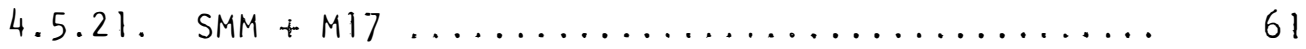

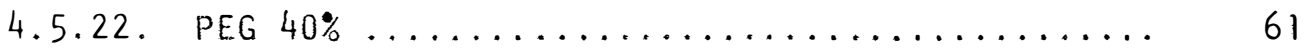

4.5.23. Tampão para digestão com enzima de restrição.. 61

- Tampão de baixa concentração salina ("Low-salt buffer")

4.5.24. Tampão para eletroforese Tris-Borato ........ 61

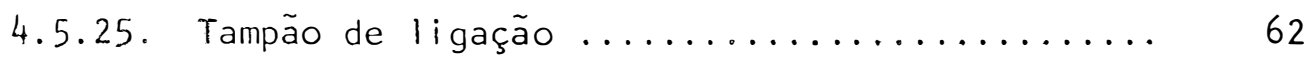

4.6. Capacidade de coagulação do leite RSM a $23^{\circ} \mathrm{C}$ durante

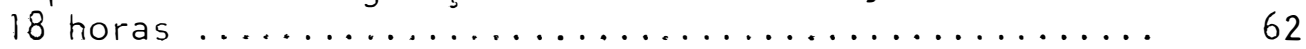

4.7. Teste de sensibilidade à temperatura .............. 62

4.8. Método de semeadura para determinação do título de bac-

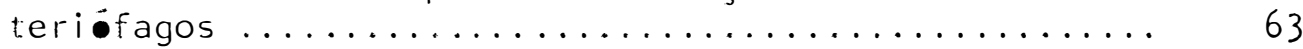

4.9. Determinação da liberação espontânea de bacteriōfagos.. 63

4.10. Verificação de lisogenia através de indução com luz ul-

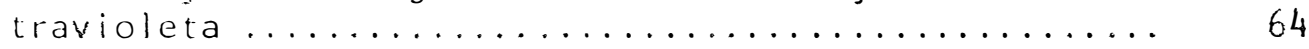

4.11. Titulação de bacteriófagos pela técnica de gotas ..... 66

4.12. Preparaçäo de estoques com alto lítulo de fagos ....... 66

4.13. Concentraçäo de fagos por polietileno-glicol ......... 67

4.14. Extraçäo de plasmidios ..................... 67

4.14.1. Micro-método para a determinação räpida de perfis plasmidiais ................... 67

4.14.2. Extração preparativa e purificação de plasmidios $\ldots \ldots \ldots \ldots \ldots \ldots \ldots \ldots \ldots \ldots \ldots \ldots . \ldots \ldots$

4.15. Eletroforese em gel de agarose ................ 70

4.16. Eletroforese bidimensional ................. 71

4.17. Estimativa do peso molecular dos plasmidios a partir de gel de eletroforese em agarose ............... 72

4.18. Titulação do DNA plasmidial e cromossômico ............ 73 
4.19. Recuperação do $2 \mathrm{ma}$ plasmidial a partir do gel de agarose ........................................ 73

420 . Obtenção e regeneração de protoplastos ............. 74

4.21. Preparáção de DVA plasmidial sob forma linear ........ 75

4.22. Extraçã̃o preparativa de DNA cromossômico ............. 76

4.23. Digestão parcial do DNA cromossômico por endonucleases de restrição .............................. 76

4.24. Centrifugą̧ão em gradiente de sacarose ............ 77

4.25. Formação do DNA recombinante $\ldots \ldots \ldots \ldots \ldots \ldots \ldots \ldots . . \ldots$

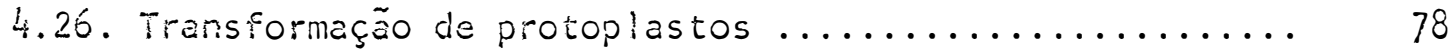

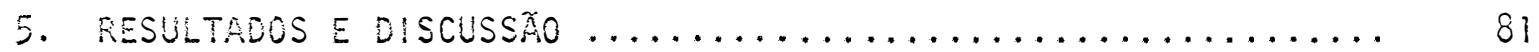

5.1. Testes tecnolögicos efetuados com estreptococos lácticos pertencentes à Coleção de Culturas Lácticas do ITAL ..........................................

5.1.1. Capacidade de coagulação do leite RSM a $23^{\circ} \mathrm{C}$ du rante 18 horas ...........................

5.1.2. Teste de sensibilidade à temperatura ......... 84

5.1.3. Teste de liberação espontânea de bacteriófagos. 89

5.2. Perfil de plasmidios de estreptococos lácticos pertencentes à coleção do ITAL ..........................

5.3. Tipagem e nivel de sensibilidade de estreptococos läct cos da coleção do ITAL a fagos virulentos pertencentes à coleção do INRA ............................. 98

5.4. Determinação de mecanismos de resistência em estreptococos lácticos da coleção do ITAL ................. 103

5.5. Verificação de lisogenia em estreptococos da coleção do ITAL por melo de indução com luz ultravioleta (U.V.) ..

5.6. Estudos feitos com o Streptococcus cremoris, Iinhagem IL 839, pertencente à coleção do INRA ...................

5.6.1. Evidência de un sistema de restriçãc/modifica-

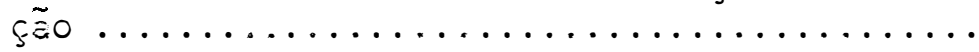

5.6.2. Caracterização e ceterminação do peso moiecular dos plasmidios de $S$. chemoris 14839 .........

5.6.3. Localização dos genes que codificam o sistema de restrição/modificação presente em S. Chemo-

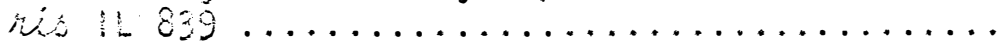


5.6.3.1. Plasmidios ............... 122

(a) Cura de plasmídios ............ 122

(b) Preparação do plasmídio plL 21 por recuperação a partir de um gel de

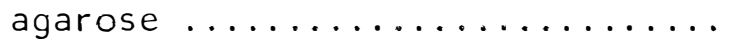

(c) Transferência do plasmídio p/L 21 por cotransformação ........... 128

5.6.3.2. Cromossomo .................. 129

(a) Extração preparativa do DNA cromossômico de S. cremorís $16839 \ldots 132$

(b) Digestão parcial do cromossomo de IL 839 por Hpa $11 \ldots \ldots \ldots \ldots \ldots$

(c) Seleção por tamanho dos fragmentos cromossomais de IL $839 \ldots \ldots \ldots .135$

(d) Fabricação do DNA recombinante ... 137

(e) Transformação ................ 137

6. CONCLUSÖES ............................... 141

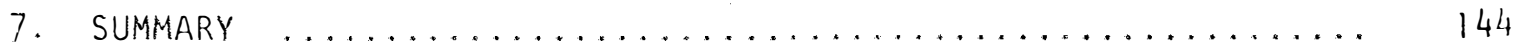

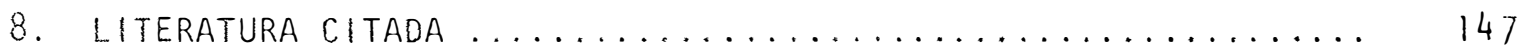


LISTA OE TABELAS

Pägina

Tabela

1. Resultados da capacidade de coagulação do leite apös incuba-

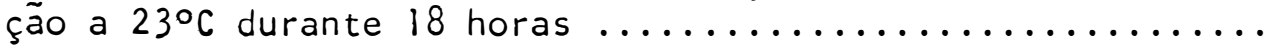

11. Efeito da temperatura de incubação na capacidade acidifican-

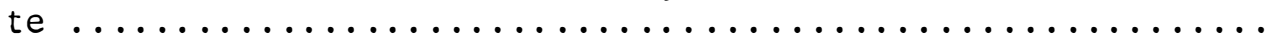

11l. Sensibilidade de estreptococos läcticos brasileiros aos fa-

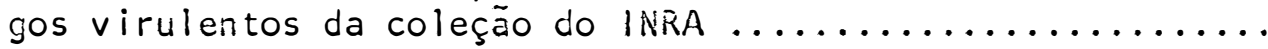

IV. Nivel de sensibilidade dos estreptococos lácticos brasileiros aos fagos virulentos da coleção do INRA ..............

V. Evidência de um mecanismo de restrição/modificação presente na linhagem 310 , ativo contra o fago $66 \ldots \ldots \ldots \ldots . . \ldots \ldots$

Vi. Evidência de um mecanismo de restrição/modificação presente na linhagem 162 , ativo contra o fago $66 \ldots \ldots \ldots \ldots \ldots$

V!I. Evidência de um mecanismo de resistência apresentado pela linhagem 105, devido a mutações sofridas pelo fago 188 ....

Vill. Espectro lítico de fagos liberados apōs indução com luz ul-

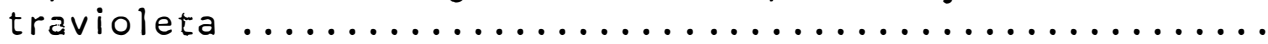

IX. Agrupamento dos estreptococos läcticos pertencentes à coleção do ITAL, de acordo com a classificação proposta por CHOPIN et alii (1976) e REYROLLE et alii (1982) ..............

$x$. Evidência da presença de um mecanismo de $R / M$ em $S$. cremaris IL 839, ativo sobre o fago $8 \ldots \ldots \ldots \ldots \ldots \ldots \ldots \ldots \ldots \ldots \ldots \ldots \ldots \ldots \ldots$ 


\section{LISTA DE FIGURAS}

Pägina

FIGURA

1. Curvas de atividade da cultura 166 com liberação espontânea de fagos, sendo $C=$ tubos-controle e $T=$ tubos-teste..

2. Curvas de atividade da cultura 280 com liberação espontânea de fagos, sendo $C=$ tubos-controle e $T=$ tubos-teste $\ldots$

3. Diferentes perfis de plasmidios de linhagens de estreptococos

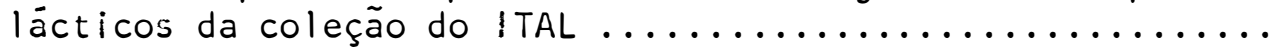

4. Diferentes perfis de plasmidios de linhagens de estreptococos

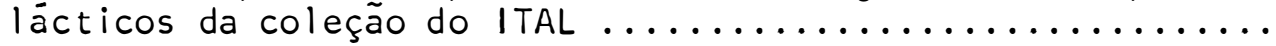

5. Perfis de plasmídios idénticos de linhagens de estreptococos

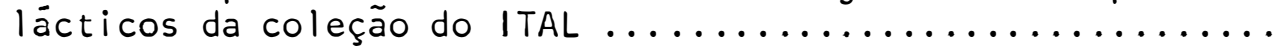

6. Evolução da densidade óptica da linhagem 96 com (T) e sem (C) indução com uma dose de $20 \mathrm{~J} \cdot \mathrm{m}^{-2}$ de radiação U.V. .....

7. Perfil e eletroforese bidimensional dos plasmídios de $S$. cre

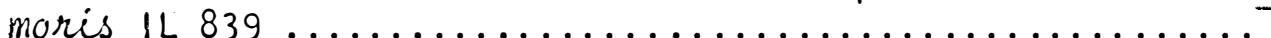

8. Eletroforese horizontal dos plasmídios PBR 322, pVA 749

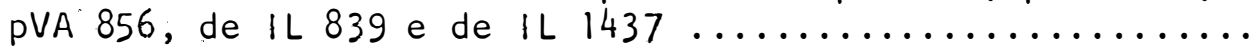

9. Perfis de plasmidios de variantes de $S$. cremoris $1 L$ 839, ob

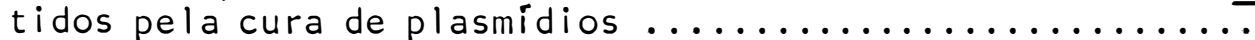

10. Perfis de plasmidios de variantes de $S$. cremoris $I L 839$, ob

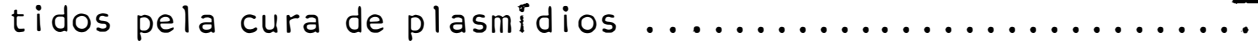

11. Eletroforese vertical de uma extração preparativa dos plas-

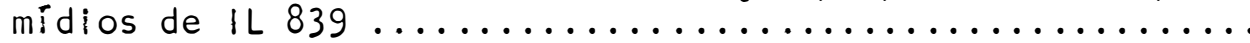

12. Eletroforese vertical de uma extração preparativa dos plasmídios de IL 839, após recorte da banda relativa ao plas-

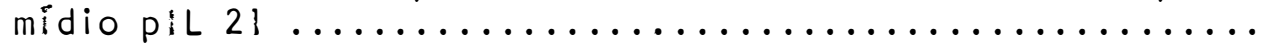


33. Transferencia de un plasmidio criptico de S. chemonis it 839 para S. Ractis 11403 por cotransformação ..........

14. Digestão parcial do cromossomo de S. chemoris 11839 pela enzima de restrição Hpa $\|$ I .................. 134

15. Eletroforese vertical dos fragmentos obtidos por digestão parcial do cromossomo ll 839 após passagem por gradiente de

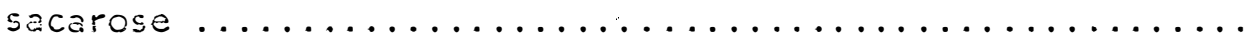

16. DNA recombinante formado pelo cromossomo de S. chemoris $1 \mathrm{~L}$ 839 e pelo plasmídio pVA 749A. (a) DNA do fago $\lambda$ digerido por Hind II; (b) cromossomo IL 839 e pVA $749 \Delta$ digeridos por Hpa li, antes de ligação; (c) cromossomo IL 839 e pliA 7494

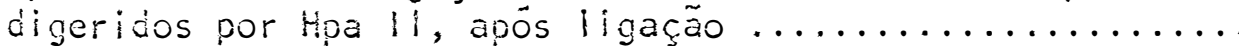


1. RESUMO

O presente trabalto foi conduzido com duas finalidaúes principais: (1) obter uma melhor caracterização de linhagens de estreptococos läcticos, pertencentes à coleção de Fermentos lä́cticos do iTAL e $\{2$ ) estudar o determinismo genëtico de um sistema de resistência a bacteriófagos presente em S. cremoris linhagem IL 339 , pertencente à coleção de culturas lácticas do INRA, com o objetivo de cloná-lo.

$$
\text { Verificou-se que dentre } 124 \text { culturas de bactērlas }
$$

lácticas pertencentes à coleçäo do ITAL, apenas 17 não cresceram a $23^{\circ} \mathrm{C}$ durante 18 horas, sendo este o primeiro teste de seleção que se efetua com culturas läcticas mesófilas. Essas culturas resistiram bem às temperaturas de cozimento, sem alte rąäo na sua atividade acidíf cante e apenas duas linhagens; 
166 280, Mberaram espontaneamente bacterióragos, não devendo ser utillizadas em fermentos lä́cticos.

Dentre 58 culturas läcticas pertencentes à mesma coleção, 21 apresentaram perfis de plasmidios diferentes, observando-se, para as restantes, $\dot{b}$ tipos de perfis anälogos. To das as culturas que possuiam perfis distintos mostraram-se lisogênicas, com liberação de profasos após indução com luz ultravioleta. Através do espectro liftico apresentado pelas mesmas em relą̧ão a fagos virulentos e aos profagos liberados, po de-se classificä-las em trés grupos, a saber: grupo $G_{1}=$ linha gem it8; grupo $G_{2}=1$ inhagens. 307 , 309,16 e 262 e grupo $G_{3}=$ Iinhagens $310,96,97,305,163,175,179,162$. Observou-se, ainda, que as culturas 310 e 152 apresentavam sistemas de restrição a modificação de $4 \log$ e 2 log, respectivamente em rela ६ão aos fagos 66,67 e 188 no caso da primeira delas e 56 para a segunda.

A Iinhagem de $S$. cremoris $1 L$ 839, apresentou um sistema de restrição e modificação de 5 log em relação ao fago 3. Verificou-se que esta linhagem possula 8 piasmídios designados de p IL 20 a plL 27 , com pesos moleculares de 3, 5, 6, 9, 14, 15, 17 e 46kb. Utilizando-se o método de protoplastizafão obteve-se cura de plasmídios, podendo-se determinar que nenhum deles estava relacionado a sistema de R/M. O plasmidio p!L 21 , não curado, foi cotransformado juntamente com um plasmí. dio indicador pHV 130!, resistente à eritromicina, para uma 
linhagem de S. lactis 111403 desprovida de plasmidios, verifi cando-se que os cotransformantes tambèm não haviam adquirido o sistema de R/M. Conclulu-se, então, que aquele sistema era co dificado por genes localizados no cromossomo.

Realizou-se digestão parcial do cromossomo com a enzima de restrição Hpa ll, posterior seieção dos fragmentos por tamanho em gradiente de sacarose e ligação dos mesmos a um plasmidio vetor pVa 7490, possuindo marca de resistência à er tromicina, também linearizado pela mesma enzima. Células de S. lactis $1 L 1403$ transformadas por este DNA recombinante possuiam somente o plasmídio vecor, o qual não consegue se manter dentro daquela linhagem descie oue possua uma inserção. 


\section{INTRODUÇÃO}

A produção da maior parte dos queijos e outros produtos derivados do leite baseia-se na fermentação läctica efetuada, principalmente pelos estreptococos do grupo $N$. Entre eles, os Streptococcus lactis, Streptococcus cremoris e Strep tococcus lactis subsp. diacetylactis são diretamente responsäveis pela acidificação do leite por meio da transformação da lactose em ácido láctico e, conseqüentemente, pelas qualidades organolēpticas dos produtos lácticos.

Enquanto que na maior parte das indüstrias de fermentação são utilizadas linhagens de microrganismos selecio nadas e melhoradas geneticamente, a indústria de lacticínios apenas dispõe, em geral, de culturas selvagens, com propriedades mal definidas e utilizadas em misturas. 
Dentre os problemas que impedem a utilização de culturas puras selecionadas, um dos mais importantes è a destruição por bacteriófagos durante os processamentos industriais. A ocorrência de fagos causa perdas econômicas muito importantes às fabricações de queijo e impede qualquer emprego racional de linhagens já me horadas para caracteres tecnológicos interessantes.

Diversas tentativas de controlar as infecções por bacteriöfagos têm sido feitas como, por exemplo, a utilização de procedimentos práticos, ou seja, a inoculação direta nas dornas de fermentação, a elaboração de meios inibidores de fagos para a multiplicação das culturas lácticas, a rotação de culturas e o uso de vários sistemas de fermentos lácticos.

os fermentos lácticos utilizados atualmente no mundo, pertencem a três grupos: (1) I inhagens mistas; (2) Ii nhagens mültiplas ou (3) linhagens simples. Entretanto, não há uma maneira de se prever dentro de quanto tempo um fago virulento aparecerà e atacarä as linhagens componentes destes fermentos. As maneiras pelas quais um novo fago surge incluem os fagos temperados de linhagens lisogênicas, fagos provenientes de linhagens selvagens presentes no leite cru, mutações em fagos jä existentes e, possivelmente, recombinaçós entre fagos virulentos e temperados.

Todos esses procedimentos, portanto, além de não prevenirem completamente a infecçäo fägica, necessitam de instrumentos que nem sempre estão disponíveis na indüstria. Ademais, os bacteriófagos multiplicam-se em profusão, sendo que 
uma fäbica pode produzir aproximadamente $10^{16}$ fagos diariamente.

As possibilidades crescentes de manipulaçöes genëticas em bactērias läcticas oferecem uma nova forma će controlar o desenvolvimento de fagos nas indústrias de lacticínios. Torna-se possivel, assim, considerar-se a construção de linhagens melhoradas por melo da clonagem de genes que codificam mecanismos de resistência a fagos.

Este trabalho teve dois objetivos principais, ou se jam:

(1) Melhor caracterização de culturas läcticas pertencentes à Coleção de Fermentos Lácticos do ITAL;

(2) Estudo genëtico de um sistema de resistēncia a bacteriöfagos com o propósito de clonä-lo. 
3. REVISÃO DE LITERATURA

3.1. Bacterias Lacticas

Por milinares de anos o homem usou a florabacteriana natural do ieite para produzir queijo e outros produtos derivados que ele uti i izava em sua alimentação. Entretanto, o conhecimento do que ocorria no leite para que ele coagulasse sö aconteceu muito tempo depois, quando em 1873 LISTER isolou - Streptococcus lactis, a bactēria läctica mais numerosa e comum no leite (SANDINE, 1980).

As bactërias läcticas apresentam-se sco duas for mas clässicas: bastonetes e cocos. São ambas Gram positivas, microaeröfllas, imöveis, nunca formam esporos, não reduzem nitri to, são proceolíticas e catalase negativas. Possuem como carac terística principal a utilização preferencial de lactose como 
fonte de carbono, produzindo, a partir dessa fermentação, quase que exclusivamente äcido läctico, no caso de bactérias homo fermentativas, ou outras substancias adicionais, tais como àci do acético, dióxido de carbono, etanol, àcido fórmico e glicerol, no caso de bactērias heterofermentativas (Kos Kowski, 1977).

De acordo com FOSTER et alii (1957) a capacidade fermentativa varia de acordo com a espécie da bactéria, obtendo-se luma produção de ä́cido läctico entre $0,5 \%$ e 1,0\%, podendo ocorrer numa ampla faixa de temperatura de $10^{\circ} \mathrm{C}-50^{\circ} \mathrm{C}$.

Segundo kOSlkowskl (1977) o àcido coagula a caseína do leite a pH 4,6, seu ponto isoelëtrico. Essa coagulaf̧ão envolve a formação de grandes agregados estruturais das mi. celas dispersas de caseína. TUMERMAN e WEBB (1965) citam que a caseina è luma fosfoproteína heterogēnea, contendo três componentes eletroforeticamente distintos, designados $\alpha, \beta$ e $\gamma$, em ordem decrescente de eletromobilidade. Citam ainda que a dispersão das micelas de caseína é regulada por um equilíbrio reversível de lons de cálcio, fosfato, citrato e magnésio no soro do leite.

Os estudos taxonómicos das bactérias läcticas iniciaram-se na segunda década deste sécuio, compreendendo, atualmente, um grande número de espécies pertencentes a quatro gêneros: Leuconostoc, Pediococcus, Lactobacillus e StreptoCOCCUS (SHARPE E FRYER, 1966). 
O gênero Leuconostoc, representado principalmente por L. chemonis, L. dextranicume L. citrovarum, é composto por pares e cadeias de células esféricas, podendo-se considerá-lo como cocos heterofermentativos, pois produzem ácido acético, etanol, díxido de carbono e ácido láctico de configuração D (EuCHANAK e GlBSons, 1975). Produzem ácido a partir de glicose, não são particularmente ativos no leite e raras vezes o coagulam, havendo algumas cepas que são incapazes de fermentar a lactose (ABO-EL-MALEK e GIBSON, 1948 e STADHOUDERS, 1974). Sua importância reside no fato de fermentar - citrato, principalmente o L. cremoris, conferindo o aroma ca racteristico do queijo (SHARPE, 1979). Em meio favorável pode produzir volumes apreciáveis de diacetil e acetil-metil-carbinol, sendo a!gumas linhagens produtoras de acetaldeído (cox, 1977; LAWRENCE et alii, 1976 e REITER, 1973).

Os Pediococcus são formados por células esféricas dispostas em tétrades, são homofermentativos, produzindo ácido láctico de configuração DL. Sua importância reside na maturação de vários tipos de queijos (DACRE, 1958 e fryer e SHARPE, (966).

os Lactobacillus são bactérias em forma de basto netes homo e heterofermentativos, com temperaturas de crescimento variando ce $10^{\circ} \mathrm{C}$ a $40^{\circ} \mathrm{C}$ e com a maioria das espëcies produtoras de ácido iáctico a partir de glicose, possuíndo, este ácido, uma configuração variāvel (FOSTER et alii, 1957 e SHARPE e FRYER, 1966). As espécies de maior interesse para a microbiologia de leite são L. casei, L. acidophilus, L. plantarum, L. 
helvericus e L. bulgaricus. Juntamente com o S. thermophilus, algu mas dessas bactérias constituem-se nos fermentos termófilos uti lizados para a produção de logurte, queijos de massa dura, leites actificados, äcido láctico e vegetais fermentados.

Algumas das bactérias läcticas mais importantes encontram-se no genero dos Streptococcus, sendo o S. Lactis, S. chemolis e S. Ractis subsp. diacetylactis os principais responsäveís pela produção de ácido läctico, aroma e sabor, a lèm das características do coägulo nas fermentações lácticas mesófilas (KLAENAMMER, 1984). Todos pertencem a grupo $N$ de Lancefileld, são homofermentativos e crescem a $10^{\circ} \mathrm{C}$ mas não a $45^{\circ} \mathrm{C}$, situando-se sua temperatura ideal em torno de $30^{\circ} \mathrm{C}$ (BRIGGS e NEWLANO, 1952, 1953). Podem apresentar diferentes comportamentos em leite, uma vez que a capacidade de obtenção de compostos nitrogenados essenciais para o seu crescimento é diferente, obtendo-se culturas diferenciadas em répidas ("fast") e lentas ("slow"), em função do seu desenvolvimanto (LAW e KolsTAD, 1983). São chamadas de räpias as culturas que crescem normalmente em leite, coagulando-o após 18 horas de incubação a $21^{\circ} \mathrm{C}$ e de lentas, as que coaguiam o leite somente apös 48 ho ras de incubação na mesma temperatura (CITT) et alii, 1965; LAVRENCE et alii, 1976 e COGAN, 1980). As linhagens lentas não pos suem, ou perderam, o sistema de proteinases sendo, então, deno minadas de prt-, a conträrio das prtt, que contêm o sistema proteolitico (MckAY, 1983). 
O S. Raciós encontra-se no le te na forma de pares de cocos elípticos ou formando cadeias curtas. De acordo com FOSTER et alie (1957), essa bactēria é essencial para a fa brisaça de cueijos e leites fermentados, auxiliando na conser vação de certos produtos läcteos protéicos que contêm hidratos de carbono. Citam, a inda, que essa espëcie prolifera em leite e fermenta a lactose, originando 0,8 a $1,0 \%$ de äcido láctico, sendo este quase que totalmente constituido pela forma L poden do-se, tamben, encontrar quantidades pequenas de äcido acetico e àcido propiónico. SWARTLMG (1951) e BRIGGS (1952) descrevem or anismos produtores de acetoina, $\mathrm{CO}_{2}$ e diacetil, similares a S. Lactis, na maioria de suas outras características, di ferindo, porém, pela sua capacidade de utilizar citratos. Estas linhagens fermentadoras de cirato receberam a denominação de S. Laciis subsp. diacetylactis.

os S. chemoris possuem muitas características em comum com S. lactis, diferenciando-se, entre outras, pela formação de cadeias longas, produção de amönia a partir de arginina, não crescimento a pH 9,2 e nem em melo contendo $4 \%$ de Nâl, velocidade de acidificação, influência no sabor e aroma do produto final e capacidade simbiótica lcollins et alii, 1950). De acordo com DAVIS (1965); LAWRENEE et adii (1976) e AnTUNES (1985), o S. chemonis é encontrado no le te cru, porëm, em numero inferior a $S$. lactis. Nos fermenos lácticos, esta

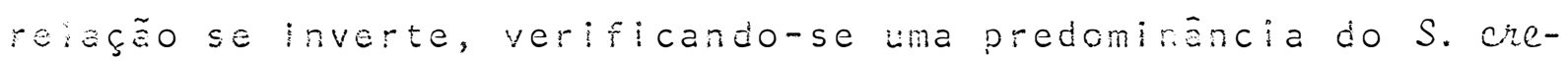
monis. Isto parece ocorrer devido à maior sensibilidade das cé Tulas de $S$. lactis ao ataque de virus que a destroem. Por esse 
motivo e tambëm pelo fato de que esse microrganismo não produz defeitos da amargor e de sabor de fruta em queijos, como aígumas Iinhagens de S. lactis, a industria de lacticinios tem demonstraco um interesse crescente por esse microrganismo nos út timos anos (RICHAROSON et alii, 1983).

O processamento de queijos e de outros produtos läcticos fermentados nasceu da necessidade de se preservar o leite cru, utilizando, para tal fim, a acidificação biológica natural e empirica. Em conseqüencia do meihoramento das qualidades higienicas do le ite, representado pela pasteurizaçäo, tornou-se necessärio substituir a flora selvagem do leite, des Eruida durante o tratamento tërmico. Esta microflora adicionada é conhecida como cultura iniciadora ("starter") cu ferment to í̀ctico.

Um fermento íâctico é composto de uma ou mais li nhagens pertencentes ou não ao mesmo gênero ou espëcie, utilizada para inocular um produto cru ou pasteurizado, a fim de iniciar uma fermentação. os mi crorganismos de queijos de massa crua e semi-cozida e de outros produtos, são os mais estudados, compreendendo os produtores de acidez, como o S. Lactis, S. lactis subsp. diaceiglactis e $S$. chemonis, e os produtores de aroma, como o Leuconostoc cremoris, L. dextranicume S. lac tis subsp. diacetylactis (LAWRENCE et alie, 1976; BOTTAZZI, 1979 e COCAN, 1980). 
Os fermentos termósilos, utilizados no fabrico de queljos de massa cozida e logurte são separados em duas categorias principais: (a) os fermentos naturais, de composif̧ão não bem definida, multo äcidos, compostos por Lactobacillus buegaricus, L. helveticus, L. lactis, L. fermentum alēm de S. thermophilus e alguns estreptococos fecais (Botrazzl, 1979 e auclair e accolas, 1983) e (d) os fermentos selecionados, de composif̧ã̄o conhecida, compostos de lima ou värias linhagens de S. thermophilus elou lactobacilos, entre esses, L. bulgaricus, L. Lactis e L. helveticus (AUCLAIR e ACCOLAS, 1983) e Propio nibacterium shermanii (LAWRENCE et alii, 1976).

A principal ação dos fermentos läcticos é acid:ficar e coagular mais rapidamente o leite pela fermentação da lactose, convertendo-a a ácido láctico, além de seus produtos metabólicos fornecerem sabor e aroma ciesejáveis e caracteristi cos ao produto final (NYIENDo et alie, 1974 e SMILEY, 1980). Pa ra que o fermento preencha esses requisitos é importante sua composição, não apenas em termos de gêneros e espécies microbianas presentes más, também, em termos de linhagens de cada espécie. Dentro da mesma espécie podem ser encontradas linhagens com diferentes intensidades metabólicas e caracteristicas bioquimicas (CORDON e SHAPTON, 1976).

Dessa forma, quando se ef́tua a seleção de linhą gens para a composição de fermentos läcticos mesófilos deve-se considerar: (1) a capacidade de produção de äcido läctico (PEARCE, 1969 a HEAP e LAVRENCE, 1976); (2) crescimento e ativiciade a 
diferentes temperaturas (BABEL, 1962; DUTTA et alii, 1972; HEAP e LAWRENCE, 1981 e OALY, 1983); (3) capacidade proteolitica ade quada, sem ocorrência de amargor no produto final (LAWRENCE et alii, 1976; COX, 1977; MARCOS et alii, 1977; SHARPE, 1979; BELOVA ex alii, 1982 e RICHARDSON, 1984); (4) resisténcia a bacteriófagos (COX, 1977; LAVRENOE ex alii, 1978; HEAP e LAWRENCE, 1981; DALY, 1983 e HUGGINS, 1984); (5) promogã̃o de transformações desejäveis durante o processo de cura (HAMOND, 1976; COX, 1977; HEAP et alie, 1978 e HUGGUN, 1984); (6) compatibilidade de crescimento en associação com outras linhagens e/ou espécies (GORDON e SHAPTON, 1976 e DALY, 1983); (7) características organolēpticas e tecnolögicas adequadas (GARCIA, 1984); (8) não produção de substâncias inibidoras (HEAP e LAURENCE, 1976) e (9) estabilidade das propriedades desejäveis de coagular a $22^{\circ} \mathrm{C}$ em 18 horas o leite reconstituido esterilizado (LAW RENCE et adii, 1978).

Em fins do sécuio passado e início deste século, Storch na Dinamarca, Conn nos Estados Unidos e Weigmann na Ale manha, iniciaram o primeiro sistema de preparação de fermentos läcticos para iniciar uma fermentação. Esta prätica fó i imediatamente adotada pelas industrias de queijo devido aos bons resultados apresentados (SANDINE, 1980). O desenvolvimento dos Fermentos läcticos foi, assim, especialmente significativo para as indústías de queijo, as quais sofieram um progresso nozäve? por poderem padronizar os seus produtos, tornando-se 
possivel corhecer o poder acidificante e a atividade bioguimica dos microrganismos que atuam nos queijos em maturação.

$$
\text { Segurdo cox (1977) e LAWRENCE et arii (1976) }
$$

existem três tipos bäs lcos de fermentos läcticos mesófíos, em relą̧̃o à sua composiģão: (1) fermento simples ou de linhagem unica, constituído de uma única linhagem de $S$. cremoris ou $S$. lactis, usado na Austrälia, ou em pares na Nova Zelandia; fermento de linhagens mültiplas, constituido de uma mistura definida, qualitativa e quantitativamente de, geralmente, três ou mais linhagens puras de $S$. cremonis e $S$. lactis, sendo ut lizado principalmente nos Estados Unidos e (3) fermento misto, composto de linhagens de S. cremoris, S. lactis, S. lactis subsp. diacetylactis e Leuconosioc, em proporçōes variáveis e, às vezes, desconhecidas; é usado, principalmente, na Europa e Amërica do Sul.

Värios fatores podem afetar o crescimento e a at ividace do fermento láctico, tais como a temperatura de processamento, o volume do inóculo, as caracteristicas genéticas da cultura, bem como a presenfa de inibidores naturais e adicionados ao leite (HULL, 1978). Dentre eles, os bacteriófagos constituem-se em um dos fatores mais importantes, sendo a prin cipal causa individua da baixa produção de äcído pelos fermentos iácticos (WHITEHEAd e COX, 1935; ELLIKER, 1951; CHRISTENSEN, 1972; CHOPIN et alii, 1976; HULL, 1978; GASSON e DAVES, 1980a e JARVIS, 1981). Dessa forma, os conceitos iniciais 
de fermentos läctícos foram modificados, visando não só à eficiência tecnológica como à utilização de linhagens resistentes a bacteriófagos, com o objetivo de controía-los. Uma revisão sobre esse aspecto encontra-se mais adiante neste mesmo capitulo.

3.2. Bacteriófagos

X Os bacteriōfagos são virus que, quando atacam as bactērias, podem causar dois tipos de conseqüèncias: a lise da célula, causada pelos chamados fagos virulentos, ou a perma nência dentro da célula hospedeira, integrado ao seu DNA; nes se caso, são chamados fagos temperados ou profagos e, este estado, de lisogenia. Um fago pode comportar-se como temperado para uma determinada linhagem hospedeira e virulento para outra; esta propriedade é determinada no hospedeiro, já que a capacidade genética para produzir a proteina repressora reside no genoma do fago (AivDERSON et alii, 1981).

os bacteriöfagos, na indüstria, podem ser provenientes do ar, de soro infectado, de partículas de leite resul tante de má higienização ou do leite cru a ser processado (WHiTEHEAD, 1953 e HULL e BROOKE, 1982), podendo sobreviver à pasteurização e à secagem por calor (CHOPIN, 1980). Alēm disso, o prōprio fermento láctico, composto por linhagens lisogénicas de bactērias lácticas possuindo um ou värios DNAs fägicos inte grados ao seu cromossomo na forma de profago (BRADLEY e JONES, 1968 ; STADHOUDERS, 1974; OVERBY, 1976; LAWRENCE et alii, 1976; 
HUGGINS e SANDINE, 1977; LAWRENCE, 1978; HEAP et alii, 1978; DAVIES e GASSON, 1981, 1983; JARVIS, 1982; CHOPIN et alii, 1983 e TEUBER e LEMBKE, 1983), representa a principal fonte natural de fagos virulentos.

As linhagens lisogênicas de estreptococos lácticos foram demonstradas primeiramente por REITER (1949), quando observou que três linhagens liberavam fagos espontaneamente, causando lise em uma linhagem indicadora apropriada. Mais recentemente, verificou-se que a lise em bactérias lácticas liso gênicas pode ser induzida por calor, luz ultravioleta (KEOGH e SHIMMIN, 1969; MCKAY E BALDWIN, 1973; KOSAK et alii, 1973; LOW RIE, 1974; PARK e MCKAY, 1975; REITER e KIRIKOVA, 1976 e HUGGINS e SANDINE, 1977) ou por mitomicina C (HUGGINS e SANDINE, 1977; SINHA, 1980 e REYROLLE et alii, 1982), de acordo com o que já havia sido descrito por HAYES (1968).

$$
\text { Uma demonstração clássica de lisogenia em } \mathcal{S} \text {. lac }
$$

tis e S. cremoris foi feita por GASSON e DAVIES (1980 a) ao ve rificarem que variantes curados de seu profago mostraram-seser indicadores sensíveis ao seu próprio fago temperado. Esses variantes podiam ser re-lisogenizados completando, assim, o ciclo temperado para o estado de profago. Observações similares foram feitas por GEORGHIOU et alii (1981), que demonstraram, inclusive, a resistência do estado de profago ao antisoro ativo contra aquele bacteriófago temperado. 
outros tipos de relações entre fagos e bactérias lácticas como, por exemplo, a pseudo-lisogenia, pelo qual um fago lítico perpetua-se em equilíbrio estável em uma população bacteriana heterogènea, composta de pelo menos uma cultura resistente a ele, dando origem freqüentemente a mutantes sensiveis, devem ser, igualmente, levadas em consideração (GRAHAM e.t ali.i, 1952; BARKSDALE e ARDEN, 1974; STADHOUDERS, 1975 e LIMSOWTIN E TERZAGHI, 1977).

A incidencia praticamente universal da lisogenia nos estreptococos lácticos indica que as linhagens lisogènicas podem servir como um reservatörio de fagos potencialmente capazes de atacar as cepas que compõem os fermentos läcticos mistos (HUGGINS e SANDINE, 1977). Dessa forma, não se deve mis turar, nos fermentos lácticos, linhagens sensiveis aos fagos temperados das demais linhagens componentes do mesmo (McKAY e BALDWIN, 1973; LAWRENCE e.t alii, 1978 e DANIELL e SANDINE, 1981). Entretanto, pelo fato de faltarem linhagens indicadoras sensiveis aos fagos temperados (LAWRENCE et alii,1976), chega-se a acreditar que estes ültimos são de menor importância e que não contribuem para o aparecimento de fagos virulentos durante o processamento industrial (TEUBER e LEMBKE, 1983). Esta hipótese foi reforçada após os estudos de homologia de DNA entre fagos temperados, induzidos a partir de três linhagens de S. cremoris e 25 (vinte e cinco) fagos líticos isolados de fábricas de queijo, verificando-se ausència de homologia genética 
entre eles (JARVIS, 1984 b). Por outro lado, a alta porcentagem de linhagens indicadoras sensiveis a fagos temperados indu zidos (REYROLLE et alii, 1982) e a estreita correlação entre os espectros de atividade de fagos temperados e virulentos (CHOPIN et alii, 1976) reforça o potencial dos fagos temperados como fontes de fagos líticos nas fermentações läcticas.

Tanto as bactérias como os bacteriófagos exibem considerável variabilidade genotípica e fenotípica. Alterações na resistência de estreptococos lácticos a bacteriófagos têm sido rotineiramente observadas (COLLINS, 1958, 1962; LIMSOWTIN e TERZAGHI, 1977; LIMSOWTIN et alii, 1978; SINHA, 1980 e SAN DERS e KLAENhAMMER, 1981, 1983). Similarmente, alterações nos bacteriófagos devidas a mutações (JARV!S, 1978) ou por modif icações controladas pelo hospedeiro (COLLINS, 1956; POTTER, 1970; KEOGH, 1973; SINHA, 1980; SANDERS e KLAENHAMMER, 1980 e DALY e FITZGERALD, 1982) podem alterar radicalmente a faixa de hospedeiros. Considerando a dinâmica das interações fago-hospedeiro durante as fermentações lácticas (LAWRENCE e THOMAS, 1979) pela própria dinâmica genética dos estreptococos lácticos (DAVIES e GASSON, 1981, 1983 e MCKAY, 1983), as alterações genéticas nos fagos temperados destes organismos devem ser igualmente di nâmicas, resultando, assim, em grande complexidade nas interações hospedeiro-fagos temperados ou liticos, levando ao aparecimento de uma população dominante de fagos líticos. 
os fagos dos estreptococos lácticos mesófilos $S$. lactis e S. cremoris tēm sido os mais bem estudados, em parti cular nos países anglo-saxões. Estes são os fagos de fermentos lácticos utilizados na fabricação do queijo cheddar. Por outro lado, pouco se sabe sobre os fagos de fermentos lácticos termó filos, S. thermophilus e diversos Lactobacillus utilizados na fabricação de iogurte e queijos de massa cozida (ACCOLAs et alii, 1980 e REINBOLD et alii, 1982). Alëm disso, os fermentos termöfilos parecem ser menos sensíveis a fagos que os mesó filos (LAWRENCE, 1978 e sozzI et alii, 1976); contrariamente, os fagos que atacam linhagens de $S$. thermophilus e L. helveticus apresentam uma alta especificidade em relação ao hospedeiro (SOZZI e MARET, 1975).

Os bacteriófagos que atacam os estreptococos lác ticos têm sido intensivamente estudados quanto à sua caracter zação morfolögica e sorolögica. Determinações das medidas e es truturas de cabeças, caudas, colares e bases desses fagos, obtidas por meio de microscopia eletrónica, demonstraram a exis tència de diversos tipos morfológicos (PARMELEE et alii, 1949; B!RADLEY, 1903, 1967; HENNING et alii, 1968; BAUER et alii, 1970; KEOGH e SHIMMIN, 1974; TERZAGHI, 1976; TSANEVA, 1976; JARVIS, 1977 ; HULL, 1978; HEAP e JARVIS, 1980; LEMBKE et alii, 1980; CHOPIN e ROUSSEAU, 1983 e TEUBER e LEMBKE, 1983). Com exceção dos fagos com cabeças tubulares descritos por CHOPIN e ROUSSEAU (1983) e daqueles com caudas contrateis descritos por TIKHONENKO (1970), a maioria dos bacteriófagos lácticos possuem cabeças prolatas, 
isométricas pequenas ou grandes e caudas não contrācteis (sozzl et alii, 1980). Apesar dos fagos com cabeças prolatas ou isométricas causarem problemas nas fermentações lácticas (TEU⿻ER e LEMBKE, 1983), os primeiros são, geralmente, mais virulentos que os segundos (HEAP e JARVIS, 1980).

Os grupos morfológicos dos bacteriōfagos lácticos foram bem correlacionados com estudos sorológicos e de homologia de DNA-DNA (ACKERMANN, 1969; TSANEVA, 1976; HEAP e JARVIS, 1980 e JARVIS, 1977, 1978, 1984 a). Estudos também foram feitos para agrupä-los de acordo com a faixa de hospedeirOS (ADAMS, 1950; BRADLEY, 1965 e CHOPIN et alii, 1976). Recentemente JARViS (1984 a) estudou quatro grupos de bacteriófạ gos läcticos quanto à morfologia, sorologia e homologia de DNA, verificando que os grupos morfológicos estabelecidos não possuíam homologia de DNA. Com estes resultados, o autor sugeriu que estes grupos de fagos não possuem um ancestral comum e que as espécies diferentes de fagos, não foramoriginadas por muta ção entre os grupos.

LAWRENCE (1978) e LEMBKE e TEUBER (1981), por meio de estudos sorológicos, feitos a partir de material cole tado em indūstrias de queijo, revelaram que o número de fagos e de culturas de estreptococos lácticos realmente diferente ë baixo e que os tipos morfologicamente distintos de fagos são pouco numerosos, parecendo haver uma correlação entre a morfologia do fago e o tipo de hospedeiro. Entretanto, os grupos de bacteriófagos definidos por meio da morfologia, sorologia ou 
homologia de DNA não mostram corrolação com os agrupamentos ba seados na fatxa de hospedelros (KEOGH e SHIMMH, 1974; HEAP e JARVS, 1980 e JARV:S, 1978, 1984a).

Ny Evoo et abii (1974) examinaram 25 fagos de estraptococos lácticos mesófllos observando que todos continham DNA de dupla flta com contedido de guanina-citosina varian do entre $32,7 \%$ e $40 \%$. Posteriormente, LEVBKE e TEUEER (1982) verificaram gue determinados fagos do tipo prolata e isometrico, comumente presentes no soro de queljo possulam teores de $\hat{Q}+0$ entre $41 \%$ e $32 \%$, respectivamente. O comprimento das mole culas de ONA desses fagos, leterminado por eletromicrografias ou por digestão com endonucleases de restrif̧äo, varia entre 18 e 27 megadaltons (Mdai) (KLAENHAMER e MCKAY, 1976; DALY e FITZGERALD, 1982 E LOOF et alí, 1983).

Apesar das espécies e linhagens de bactérias com ponentes de fermentos lácticos serem suscetiveis a ataque de bacteriófagos, não são necessariamente sensiveis às mesmas raGas de fagos (CALAM, 1964; KEOGH, 1972; STADHOUDERS, 1974; LAM RENCE et alii, 1976; LIMSOWTIN et alii, 1977 e HEAP et alii, 1978). O estudo mais extensivo sobre os cruzamentos fago-hospedeiro em estreptococos iácticos foi feito por CHOPin et alii (1976) com 132 fagos usados contra 20! linhagens. Observaram que $68,8 \%$ das Yinhagens ensaiadas foram sensíveis ao grupo "g3" de fagos, podendo-se concluir que a maloria das linhagens de estreptococos läcticos são suscetiveis a bacterióragos de ampla 
faixa de hospedeiros. Dessa forma, o grau de diversidade na faixa de hospedeiros dos bacteriófagos lácticos é muito maior do que o inicialmente imaginado.

A determinação de numerosos cruzamentos com fagos heterólogos que apresentam baixa eficiēncia de formação de placas de lise (ORAM e REITER, 1968; TERZAGHI e TERZAGHI, 1978; PEARCE, 1978; BOUSSEMAER et alie, 1980 e SANDERS e KLAENHAMMER, 1980) foi facilitada com o uso de preparações contendo alta con centração de fagos (LAWRENCE et alii, 1976 e HEAP e LAWRENCE, 1976) e, principalmente, pelo desenvolvimento de meios tampona dos como o MI6 (LOWRIE e PEARCE, 197la), triptona-extrato de levedura-āgar (KEOGH, 1980) e MI7 (TERZAGHI e SANDINE, 1975). Destes, o meio Ml7, tamponado com $\beta$-glicerofosfato, tem sido - mais utilizado para ensaios de formação de placas de lise, melhorando, indubitavelmente, a deteç̧ão do desenvolvimento de fagos heterólogos nos estreptococos lácticos. Isto porque este meio, além de manter o pH acima de 5,7, deixa o elemento cálcio livre, necessário para adsorção dos fagos à parede celular microbiana.

Segundo SANDINE (1980), o processo de infecção dos estreptococos lácticos pelos bacteriófagos consta de' quatro estágios: (a) adsorção, onde os fagos se prendem aos sítios receptores na cëiula hospedeira, geralmente pela caudae (b) infecção do DNA fágico, dependentes de cálcio; (c) período latente onde, para os fagos virulentos, a capacidade biossintética da célula torna-se comprometida para a produção de DNA e proteína 
do fago, os quais, posteriormente, se reunirão para formar o fago maduro; e (d) a eclosão, quando os fagos viäveis são libe rados no melo através de lise das células.

A interação entre a bactéria e o fago é altamente especifica (PARADA et alie, 1984) e depende da presença de receptores fágicos reativos localizados, em algumas linhagens, na parede da célula (ORAM e REITER, 1968) e, em outras, na mem brana plasmätica (ORAM, 1971 e HURST e STUBBS, 1969). Subseqüiente caracterização dos receptores fägicos demonstrou serem estes de natureza lipoprotéica com componentes polipeptídicos (ORAM, 1971 e KEOGH e PETTINGILL, 1983).

o grau de adsorção dos fagos pode ser grandemente afetado pela disponibilidade do cátions mono ou bivalentes (CHERRY E WATSON, 1949 b). REITER (1956) observou que os bacteriōfagos eram inibidos em meio deficiente em cälcio. Posteriormente, HARGROVE (1959) relatou que o uso de fosfato no leite impedia o crescimento de fagos nos fermentos läcticos. Os ànions fosfato seqüestram os ions câicio, tornando-os não disponiveis aos fagos que os necessitam para injetar seu DNA na célula (WATANABE e TAKESUE, 1972). Entretanto, essas reações não são específicas para o cälcio ou qualquer outro cātion (CHERRY e WATSON, 1949 b; POTTER E NELSON, 1952 ; REITER E MØLLER- NADSEN, 1953 a ORAM e REITER, 1958). Outros fatores adicionais exirínsecos que podem afetar a adsorção dos fagos pelos estrep tococos lácticos incluem mudanças no pH (CHERRY e WATSON, 1949 a e KEOGH e PETTINGILL, 1983) e a temperatura (KEIGH, 1973 e SANDERS E KLAENHANMER, 1984 . 
De modo geral, os fagos são bem adsorvidos pelo seu hospedelro homólogo, seguindo-se o ciclo littico normalmente. Encretanco, vários cruzamentos entre hospedéro e fagos heterólogos que demonstram adsorģäo eficiente falham no desenvolvimento do cicho lïtico (ORAM e REITER, 1968) ou apresentam báxa eficiência de formagão de placas de lise (SANoERs e KLAE NHAMER, 1980, (983). Este tipo de resposta é devido à presença de sistemas de restrição/modificą̧ão (PEARCE, 1978; BOUSSEHAER et adii, 1980; SANDERS e KLAENHAMMER, 1980 e DALY e FITZGERALD, 1932), a outros mecanismos de defesa conhecidos (SANDERS e KLAENHAMVER, 1983, 1984) ou, simplesmente, à impossibilidade do fago adsorvido replicar-se no hospedeiro. As alteraçoes na especificidade adsortiva dos bacterioragos podem ser devidas às mudanças nos hospedeiros ou nos pröprios fagos, cau sadas por mutações ou por modificações induzidas pelo hospede rO (COLLINS, 1958; ORAY E REITER, 1968; KEOGH, 1973; LIMSOWTIN e TERZAGHI, 1976; JARVIS, 1978 e KING et ariz, 1983).

Já foi evidenciado, tambēm, que alterações nas propriedades de adsorfão dos estreptococos lácticos podem ser devidas, em alguns casos, à aquisiça ou perda de plasmídios. Assim, SANDERS e KLAENHAMMER (1983) mostraram que a perda de um plasmídio de 30 Mdal em uma linhagem de S. lactis Ne 2 , não sensivel a fagos, aumentou sensivelmente a adsorção de quatro fagos heterólogos, assím como a efíléncia de formação de placas de ilise. Similarmente, oe vos et alid (1984) verificaram que a adsorgão de um fago por S. chemohis SLî aumentou de 5\% 
a 90\% apos a pera de um plasmídio de 34 Mdal. o envolvimento de piasmidios nos mecanismos de defesa a fagos e nos estreptococos läcticos pode explicar, en parte, a grande variabiiidade e instabillidade nas relaçoses tago-hospedeiro comumente observa das nessas bactërias.

Seguindo-se à adsorfão, o DNA do fago é injetado na célula bacteriana, ocorrendo sua multiplicação. A propagaGão de fagos lifticos pode ser um processo räpido, comperíodos Iatentes curtos e líberação de grande nümero de f́agos após a lise da célula. Cada novo fago liberado poderä infectar uma no va cé!ula sensívei (BRAdLEY e JONES, 1963 e OVEREY, 1976). Cs periodos lacentes variam de 9 a 139 minutos (ZEHREn a WHITEHEAD, 1954 e LAWRENCE et adil, 1976) com a maioria ocorrendo entre 40 a 50 minutos a $30^{\circ} 0$ (KEOGH, 1973).

A magnitude de eciosão é multo variävel entre os estreptococos iácticos, variando de ga 105 partículas liberadas por cälula intectada (KEOGH, 1973). Em altas temperaturas, os periodos latentes são geralmente reduzidos, porém, a eclosão pode aumentar, decrescer ou permanecer inalterada (ZEHREN e WHITEHEAD, 1954 e KEOGH, i973). Periodos latentes curtos, am pla eclosão ou ambos são características de rafas de fágos que se desenvolvem rapidamente, atingindo grandes populaçōes no SOro de queijo (ZEAREN e WHITEAEA, 1954). Estes fagos são con siderados como possuindo altos "fatores de multiplicaçăo" lpEARCE et aldi, 1970 ) determinados pelo teste da atividade com o 
fermento láctico, podendo causar faiha total do mesmo, ainda que presente em baixas concentrações no início do processamento de queijos (LAWRENCE et alii, 1976).

A multiplicação dos bacteriófagos nos estreptococos läcticos depende de vārios fatores nutricionais, especificamente de eletrólitos que são ativos tanto na replicação dos fagos como na lise da célula. Assim, fosfato de potássio, cloreto de södio e cálcio, sulfato de magnésio e acetato de sọ dio podem aumentar a eficiência de lise por bacteriófagos em S. lactis, porém, este efeito está estreitamente correlacionado com a eficiência de adsorção do fago (CHERRY e WATSON, 1949b). Contrariamente, a remoção de triptona do meio reduz a eclosão mas não altera a eficiência de adsorção do fago. Diversos estü dos demonstraram que a replicação da maioria dos fagos depende de cálcio em concentrações ideais de $2,7 \times 10^{-4}$ a $1,7 \times 10^{-3} \mathrm{M}$ (COLLINS et alii, 1950; POTTER e NELSON, 1952; ORAM e REITER, 1968 e sozzl et alii, 1980), apesar do mecanismo utilizado não estar bem determinado (LAWRENCE et alii, 1976).

outro fator que afeta o desenvolvimento lítico dos fagos nos estreptococos läcticos é a temperatura a qual ge ra, normalmente, respostas bem variadas. A maioria dos fagos possui uma temperatura ótima de replicação idêntica à ótima pạ ra crescimento da bactēria hospedeira, ou seja, $30-32^{\circ} \mathrm{C}$ (WHITEHEAD e COX, 1936 e SOZZl et alie, 1978). Entretanto, algumas vezes, temperaturas altas podem inibir a multiplicação dos fagos (KEOGH, 1973 e MULLAN e.t alii, 1981) ou aumentá-la (HUNTER, 
1943; PEARCE, 1978; SANDERS E KLAENHAMMER, 1980; DANIELL E SAN - DINE, 1981 e HULL e BROOKE, 1982). O estimulo da alta eficiência de formação de placas de lise em cruzamentos com fagos heterólogos, normalmente de baixa eficiência, por temperaturas elevadas (PEARCE, 1978) ou por choque de calor (SANDERS e KLAE NHAMMER, 1980) parece resultar da inativação fenotípica dos sis temas de restrição/modificação, levando o fago a se multiplicar em hospedeiros normalmente restritivos.

\subsection{Sistemas de Restrição/Modificação}

Após a entrada do DNA fágico dentro da célula, a bactéria pode permitir a sua replicação, resultando na propa gação do fago, abortar a infecção nos casos em que o fago não se compatibiliza com os sistemas de replicação do hospedeiro, destruir o DNA do fago por meio de enzimas de restrição ou, em menor frequéncia, modificar quimicamente aquele DNA de tal for ma, que ele não seja reconhecido pelas enzimas de restrição, permanecendo apto para completar seu ciclo lítico (KRÜGER e B (CKLE, 1983).

$$
\text { O mecanismo clássico de restrição e modificação }
$$
$(R / M)$ de bacteriófagos consiste em duas atividades enzímicas: (1) a enzima de restrição é uma endonuclease capaz de 'cortar - DNA fágico em sítios que não haviam sido previamente modificados e (2) a enzima de modificação é uma metilase ou glicosílase que adiciona un radical nas palindromes, as quals se tornam, então, modificadas (MESELSON et alii, 1972; ARBER, 1974; 
B।CKLE, 1982; MCCLELLAND, 1981 e YUAN, 1981).

A adaptação de fagos heterólogos pela modificação controlada pelo hospedeiro leva a um desenvolvimento lítico irrestrito no novo hospedeiro; entretanto, tais modificações são reversiveis e determinadas pelo último hospedeiro no qual o fago foi propagado, distinguindo-se, assim, de mutação (LURIA, 1953). Enquanto os sistemas de restrição e modificação constituem o principal mecanismo de defesa contra a infecção por bacteriófagos heterólogos, por outro lado, as enzimas de modificação fornecem a oportunidade de adaptação do fago em novos hospedeiros (KLAENhAMMER, 1984).

A existencia de sistemas de R/M nos estreptococos lácticos já está bem estabelecida, sabendo-se, atualmente, que estão amplamente distribuídos neste gênero de bactérias, podendo existir sistemas múltiplos de R/M em uma única linhagem (COLLINS, 1956; BOYER, 1971; MESELSON et alii, 1972; LAWRENCE et alii, 1976; PEARCE, 1978; LIMSOWTIN et alii, 1978; SANDeRs e KLAENhammer, 1980; bOUSSemaer et alii, 1980; daly e FITZGERALD, 1982; DAVIES e GASSON, 1981, 1983; MCKAY, 1983; TEUBER e LEMBKE, 1983 e CHOP!N et alii, 1984).

FITZGERALD et alii (1982) isolaram uma endonuclea se de restrição, $S c r F_{1}$, do tipo 11 , de seqüência específica em S. cremoris $F$. Este estudo forneceu a primeira evidencia. bioquímica da existência de enzimas de restrição em estreptococos iácticos. Apesar da linhagem expressar restrição e modificação 
dos fagos dependentes do hospedeiro, não se sabe se a enzima ScrF, opera "in vivo" como parte do sistema de R/M da célula.

LIMSOWTIN et alii (1978) verificaram que a manutenção de um sistema de R/M era instävel em uma linhagem de $\mathcal{S}$. cremoris e especularam sobre uma possível localização extra- cromossómica dos genes que codificam esse sistema. Posteriormente, SANDERS e KLAENHAMMER (1980, 1981) associaram a existência de um sistema de R/M, tambèm em $S$. cremoris, a um pla mídio de 10 Mdal pois, os variantes que o haviam perdido repli cavam o fago $C_{2}$ ensaiado com mais eficäcia. Observaram, ainda, que a atividade de modificação foi simultaneamente perdida naqueles mutantes, demonstrando que o plasmídio curado codificava para ambas as atividades. Uma observação similar foi feita para a atividade restritiva de $S$. lactis subsp. diacetylactis F7/2 por TEUBER e LEMBKE (1983). Também CHOPIN et alii (1984) estabeleceram que dois plasmídios, de 28 e 31 kb cada, codificavam sistemas de R/M em $S$. lactis.

SANDERS e KLAENHAMMER (1981) verificaram, entretanto, que os mutantes que haviam perdido o plasmídio que cod ficava um sistema de R/M, apesar de terem reduzidas suas ativi dades de restrição e modificação apresentavam, ainda, alguma restrição ao fago em estudo. Concluiram, então, que havia outros sistemas de $R / M$ adicionais na linhagem estudada, os quais eram independentes daquele ligado ao plasmídio curado.

A eficiència dos sistemas de R/M nos estreptococos läcticos pode ser retardada quando as condiçóes ótimas 
de crescimento ou experimentação são alteradas. Assim, LOWRIE (1974) mostrou que células de S. Cremoris AMl em fase estacionäria de crescimento foram muito mais sensíveis ao fago heterólogo de $S$. Cremoris $R_{1}$ do que aquelas em fase logaritmica de crescimento. Da mesma forma, TERZAGHI e TERZAGH (1978) verificaram que células mais velhas, crescidas em meio com níveis altos de lactose exclusivamente, demonstraram habilidade reduzida de restringir o desenvolvimento de fagos heterólogos. Este efeito foi atribuido parcialmente aos baixos valores de pH alcançados durante o crescimento das culturas em concentrações ilimitantes de lactose.

Temperaturas elevadas podem, igualmente, alterar a capacidade restritiva dos estreptococos lácticos durante o ataque por bacteriöfagos heterölogos. Assim, PEARCE (1978), en saiando o fago 643 contra 23 linhagens de $S$. lactis e S. cremoris, observou que a, eficiência de plaqueamento aumentara de, pelo menos 2 log, em 5 linhagens diferentes, quando a temperatura de incubação foi alterada de 30 para $37^{\circ} \mathrm{C}$ observações similares foram feitas por SANDERS e KLAENHAMMER (1980) em relação à baixa eficiència de cruzamentos de fagos restritos em S. cremoris SH e S. cremoris 799; após aumento de temperatura na incubação das linhagens, as progênies de fagos modificados produzidas eram capazes de desenvolvimento lítico total nos hospedeiros anteriormente restritivos. MCKAY e BALDWIN (1984) demonstraram a existência de um plasmídio de 40 Mdal em S. Lac tis subsp. diacetylactis, conferindo resistēncia a fagos 
naquela cultura somente a temperaturas entre 21 e $32^{\circ} \mathrm{C}$, sendo sua replicação, portanto, termossensível. Estes dados indicam que temperaturas elevadas podem ocasionar o aparecimento de uma população de fagos modificados, com capacidade de lisar os hos pedeiros que antes os restringiam, por meio da perda temporária dos sistemas de R/M nessas bactérias. Dessa forma, as elevadas temperaturas utilizadas na manufatura de queijos podem contribuir diretamente para o surgimento de novas populações de fagos líticos, por meio do aumento da capacidade de replica ção de fagos heterölogos em culturas que sofreram um choque tér mico.

Conclui-se, a partir desses fatos, que essas bac tērias possuem sistemas de defesa a bacteriófagos independentes dos sistemas clässicos de restrição e modificação, os quais são rapidamente anulados em temperaturas elevadas. KR̈̈GER et alii (1980) e KRÜGER e BICKLE (1983) observaram que a restrição e modificação fenotípica de viroses bacterianas tambēm pode ocorrer, por um mecanismo que envolve uma modificação na proteína, e não no DNA do fago. Dessa forma, a capacidade do fago ser adsorvido por uma nova célula hospedeira é influenciada pela modificação conferida ao fago quando de sua passagem pelo hospedeiro anterior. Por outro lado, os bacteriófagos também desenvolveram diferentes mecanismos para evitar os efe tos de restrição apresentados pelas bactērias, os quais têm si do encontrados em praticamente todos os fagos já examinados (KRÜGER e BICKLE, 1983). 
A expressão de sistemas mültiplos de R/M numa ún ca linhagem de estreptococo láctico fornece-lhe uma forte barreira de proteção contra o ataque de bacteriófagos heterólogos. Conseqüentemente, a aquisição ou perda de um plasmídio que codifica sistemas de R/M podem fortificar ou enfraquecer essa barreira. Como os plasmídios são instáveis, podendo ser perdidos facilmente com o sub-cultivo contínuo, há possibilida de de se acumularem variantes deficientes quanto à capacidade restritiva, constituindo-se, esses ültimos, em reservatōrio de hospedeiros para a replicação de fagos heterólogos (LIMSOWTIN et alii, 1978; SANDERS e KLAENHAMMER, 1981 e KLAENHAMMER, 1984).

3.4. Controle de Bacterióbagos

Vários procedimentos têm sido utilizados na tentativa de minimizar o ataque de fagos durante as fermentações lácticas, tais como: (1) meios inibidores de fagos; (2) culturas concentradas; (3) inoculação direta nas dornas de fermentação; (4) rotação de culturas; (5) värios sistemas de fermentos lácticos; (6) mutantes resistentes a fagos e (7) linhagens insensiveis a fagos.

A prevenção da contaminação por bacteriōfagos durante a preparação dos fermentos lácticos a ser utilizados na indústria é essencial, devendo ser mantida a assepsia e meios inibidores de fagos. Os primeiros recipientes especiais, para a preparação dos fermentos lácticos, que previnem a infeç ção fägica, foram desenvolvidos na Nova Zeländia (WHITEHEAD, 1953 e SANDINE, 1977). Não tendo sido usados em associação 
com meios inibidores de fagos (LAWRENCE et alii, 1976 e SANDIne, 1977) e mesmo sendo, alguns deles, desenhados como sistemas fechados (WIGLEY, 1980), não estavam totalmente livres de contaminação. Conseqüentemente, uma prática comum nos Estados Unidos passou a ser a preparação dos fermentos em meios inibidores de fagos. Estes meios são preparados a partir de soro deionizado e suplementados com hidrolisados de proteína e amônia, alēm de fosfatos, os quais formam quelatos com cátions divalentes, especialmente o cälcio (HARGROVE et alie, 1961; ZOI TOLA e MARTH, 1966; HENNING et alii, 1965 e GULSTROM et alii, 1979). Quando o cálcio não está disponível, a proliferação da maioria dos bacteriófagos è inibida (COLLINS et alie, 1950; POT TER e NELSON, 1953; REITER e MDLLER-MADSEN, 1963). A eficácia destes tipos de meios depende do tipo e concentração do fosfato (HARGROVE et alii, 1961 e ZOTTOLA e MARTH, 1966), do pH do meio (HARGROVE et alii, 1961 e AUSAVANODOM et alii, 1977) e dos requisitos específicos da interação fago-hospedeiro (sozzl et alie, 1980), já que nem todos os fagos requerem cálcio para efetuar seu ciclo lítico (sozzl, 1972).

Os meios inibidores de fagos não foram adotados em todas as indústrias, especialmente na Austrāi ia (HULL, 1983), pois podem ser inibidores para algumas culturas lácticas (czuLAK e KEOGH, 1957 e BABEL, 1958).

Dois tipos de avanços foram feitos no uso de meios inibidores de fagos para o preparo dos fermentos lácticos. 0 
primeiro foi a utilização do soro proveniente de processamentos adicionado de fosfatos e com controle externo de pH (AUSAVANODOM et alii, 1977; CHEN e RICHARDSON, 1977; RICHARDSON et alii, 1976 e WRIGHT e RICHARDSON, 1982). A utilização deste tipo de meio reduziu sensivelmente os custos de preparação dos fermentos. O segundo deles foi desenvoivido por SANDINE e AYRES (1981), com a utiiização de um meio contendo fosfatos insolúveis em ägua eliminando, assim, o controle externo de pH e exibindo não só uma excelente inibição de fagos, como estimulando o crescimento e atividade das culturas läcticas $x$

A utilização de culturas concentradas, as quais podem ser inoculadas diretamente nas dornas de processamento, forneceu uma alternativa à preparação prévia dos fermentos e ao uso de meios inibidores de fagos. Como esses concentrados são preparados assepticamente, não hä possibilidade de contami nação fägica antes de sua inoculação direta nas dornas (EDDY e RAYFIELD, 1978). Elas são congeladas e estocadas em temperaturas que variam de -70 a $-196^{\circ} \mathrm{C}$ (PORUBCAN e SELLARS, 1979). Ape sar de serem altamente ativas, os gastos exigidos para sua di $\underline{s}$ tribuição e estocagem em temperaturas extremamente baixas restringem sua ampla utilização nas indūstrias de laticínios. Uma alternativa seria o uso de culturas concentradas liofilizadas, por serem menos caras quantó à distribuição e estocagem; entretanto, elas são menos ativas, necessitando ser reativadas atravēs de uma sērie de repicagens intermediärias antes de 
inoculadas nas dornas de processamento (PORURCAN e SELLARS, 1979 e YANG e SANDINE, 1979). Atualmente, existem fermentos liofil i zados superconcentrados que podem ser inoculados diretamente nas dornas, suprimindo transferēncias intermediärias.

WHITEHEAD (1953), concluindo que a infecção das bactērias läcticas por bacteriófagos não poderia ser totalmente eliminada durante os processamentos de queijo, tentou reduzir os níveis de fagos na indūstria por meio de práticas de hi giene e pelo uso de um sistema de rotação de culturas. Para tanto, utilizava linhagens aos pares durante quatro dias, partindo do princípio de que se uma delas fosse atacada por fagos, a outra poderia continuar a produção de ácido láctico. Ao final daquele período, quando a concentração de bacteriófagos es pecíficos para aquele determinado par de culturas estivesse elevada, a utilização de um novo par a reduzia a níveis mínimos por não serem os mesmos, capazes de infectar este novo par. Este plano de ação forneceu a base para a criação do sistema misto de fermentos lácticos e os programas de rotação de cultú ras que são utilizados até hoje.

COLLINS (1958) sugeriu que os níveis de fagos re siduais não eram suficientemente reduzidos no período de rotação, a fim de prevenir a baixa produção de ácido pelas linhagens sensíveis aos fagos líticos presentes na indústria. Esse mesmo autor (1962) propós a substituição das linhagens sensíveis na rotação imediatamente após o aparecimento de bacteriófagos e sua substituição por uma outra linhagem não relacionada 
àquele fago em questão. Entretanto, observou que, na verdade, existem muito poucas linhagens de estreptococos lä́cticos näo relacionadas quanto à sensibilidade a fagos, disponíveis para serem utilizadas neste tipo de programa. Consequentemente, a eficiência e longevidade dos programas tradicionais de rotaça de culturas e substitui̧̧ão de linhagens são severamente limitadas (CHOPIN et alii, 1976; LAWRENCE et alii, 1976 e EDDY e RAYFIELD, 1978).

\section{Como já dito anteriormente, o problema causado} pelos bacteriófagos modificou a concep̧ão inicial dos fermentos lácticos, associando-os com programas de rotação de culturas e de substituif̧ão de linhagens sensiveis por outras resistentes a fagos. LIMSOWTIN etali (1977) consideram que o desconhecimento da composição do fermento misto pode acarretar trans tornos à regularidade dos padrões de qualidade dosqueijos, principalmente se não forem utilizadas técnicas adequadas de manutenção das culturas nos laboratörios das fábricas de queijo. Este tipo de fermento surgiu, como já citado, a partir do programa de rotação de culturas criado por WitteHEAD (1953). Dessa forma, sofre restrições em reiação à utilização de culturas não homölogas a fagos (EDDY e RAYFIELD, 1978). Ademais, a prätica de rotação de um grande nümero de linhagens nos fermentos mistos ë de dificil execução, oferece pouca proteção contrabac teriófagos e poderia, de fato, não sö promover a sua prolifera ção, como o aparecimento de diferentes tipos defagos (iviLL, 1978 e THUNELL et alii, 1981). 
KEOGH (1972) cita que os fermentos simples, cons tituidos teoricamente por um ünico tipo de microrganismo, apre sentam vantagens quanto à manutenção das características de qualidade dos queijos, pela facilidade no controle de seu desempenho. Na prätica, esses fermentos são muito utilizados na forma pareada, o que ajuda a conferir, às culturas, resistência a bacteriófagos, sal e variações de temperatura (Boyd e TARR, 1955). 0 sucesso de sua utilizaçăo depende, porém, da manutenção estrita da pureza e atividade da cultura, à rigorosa assepsia em todas as etapas de sua manipulação, além da ado ção de um cuidadoso programa de rotação de culturás não homólo gas em relação aos fagos, por períodos não superiores a $4-6$ dias (KEOGH, 1972). Entretanto, como o nümero dessas linhagens não homölogas a fagos é limitado e difícil de ser reconhecido, o programa de rotação usarä, inevitavelmente, Iinhagens fago-relacionadas (LAWRENCE, 1978 e EDDY e RAYFIELD, 1978). Uma vez presentes em altos niveis na indüstria, a faixa de hos pedeiros desses fagos pode ser expandida por meio de mutaçãono fago ou por modificação controlada pelo hospedeiro (HEAP e LAW RENCE, 1976; JARVIS, 1978 e SANDERS e KLAENHAMMER, 1980,1981$).$

0 uso do fermento de linhagens múltiplas tem for necido, atualmente, uma alternativa aos outros programa tradicionais de rotação de culturas (LIMSOWTIN et alik, 1977; RICHARDSON et alie, 1930; DANIELL e SANDINE, 1981 e THUNELL et alii, 1981). Assim que são detectados fagos líticos a qualquer 
das linhagens componentes do fermento, a linhagen sensivel é substituida por uma outra nova (LIMSOWTIN et alie, 1977) ou por um mutante resistente ao fago (RICHARDSON et alie, 1980 e THUNELL et alii, 1981). Este tipo de fermento é efetivo somente quando as linhagens selecionadas podem resistir a a taque de bacteriöfagos por um tempo suficientemente longo para que seu uso possa ser vantajoso (HEAP e LAWRENCE, 1976 e LIMSOWTIN et alii, 1977). A manutenção deste sistema requer um esquema de trabalho voltado muito mais a um programa de pesquisa do que de produção, tornando-se, portanto, impraticável para a maioria das indüstrias.

A seleçäo de linhagens não relacionadas a fagos e que possuam, ainda, bom desempenho tecnolögico pode ser fe ta por meio de um teste de atividade proposto por HEAP e LAWRENCE (1976), o qual prediz a longevidade de utilização de uma determinada linhagem em condicoes de processamento. Assim, as I inhagens sob consideraçäo são sujeitas a repetidos ciclos de crescimento em presença de preparaçes contendo alto título de fagos coletados nas proprias indústrias e utilizando-se condições de temperatura que imitam as relações tempo/temperatura en contradas durante os processamentos. Este estudo enfatizou a importancia da temperatura, tipos e níveis de fagos no aparecimento de bacteriófagos liticos nas indüstrias de queijo. 0 teste de atividade em laboratörio fornece, significativamente, uma maneira de se predizer, portanlo, se um fago apareceră 
rapidamente ou não, contra uma linhagem introduzida numa indús tria. Posterioment e, LIMSOWTIN et atii(1977) formularam um fer mento lácticomültiplo, composto de 06 linhagens, todas selecionadas pelo leste de atividade para resistência a fagos, o qual foi utilizado continuamente de dois a oito méses com sucesso. Apös esse período, apesar da atividade não ter sido afe tada, os fagos liticos apareceram contra quatro daquelas linha gens. Consequentemente, os autores recomendaram que as linhagens sensíveis deveriam ser substituidas assim que os fagos fossem detectados.

Mutantes resistentes a fagos surgem espontaneamente por meio de alterações na célula, impedindo a adsorção, infeç̧ão ou replicação de um fago específico ou um grupo relacionado a fagos. Entretanto, apesar de variantes imunes a fagos poderem ser isolados a partir de culturas lisadas em leite, estäo sujeitos ao ataque por um novo fago ou perdem, gradualmente, sua resisténcia ao fago lítico de origem; além disso, pode ocorrer uma alteraçăo em sua capacidade de produzir àcido láctico (WHITEHEAD, 1953; COLLINS, 1955; LIMSOWTIN e TERZAGHI, 1976; :ARVIS, 1981 e KING et alii, 1983). Paralelamente ao fato de nem sempre ser possivel isolar mutantes resistentes para todas as combinações fago-hospedeiro (LIMSOWTIN e TERZAGHI, 1976 e JARVIS, 1981), quando esses podem ser isolados, fornecem proteçăo à cultura láctica por pouco tempo (WHITEHEAO e COX, 1936), com raras exceçÕes (LIMSOWTIN e TERZAGHI, 1976; JARVIS, 1981 e THUNELL et alii, 1981). 
Segundo THOMAS e LOWRIE (1975), HULL (1977 a) e CZULAK et ali (1979), uma das formas de se isolar mutantes re sistentes a fagos é por meio de propagação diária do fermento juntamente com amostras frescas de soro expondo, continuamente, dessa forma, as culturas aos fagos que aparecem na indústria. Essa idéia é reforçada pelo fato de existirem os chamados "fagos de leite cru", que se mostram ativos contra as culturas do fermento somente sob condições de processamento, não causando problemas durante a preparação dos fermentos em laboratório. Eles são, frequentemente, o tipo mais comum de fago encontrado nas fábricas, podendo causar o declínio da resistência dos mutantes resistentes isolados (HULL e BROOKE, 1982). De acordo com HULL (1983), a efetividade deste periodo depende de: (1) obtenção de amostras de soro representativas da popula căo de fagos da fabrica e (2) o uso de um sistema de testes que incorpore ralores (condicões de processamento), importanles na multiplicaçao de fagos, tais como temperatura, meio e nat ureza do fermento. Sob cstas circunstāncias, a seleção cons tante de mutantes resistentes a fagos nos fermentos ocorre naturalmente. Entresanto, essas culturas variam consideravelmente nas taxas de p-odução de àcido läctico, devido ao acúmulo de variantes lentos na população (STADHOUdERS, 1975 e THOMAS e LOWRIE, 1975). Is so prejudica consideravelmente os processos atuais de processamento de queijo, sendo este método, portanto, inaceitàvel (LAWRENCE, 1978). 
0 tipo mais comum de mutação que ocasiona resistência a fagos é aquele que causa uma alteração nos sítios receptores da superfície da célula (KING et alii, 1983). Isto pode afetar, simultaneamente, os sistemas de transporte de car boidratos para a célula ou a produção de proteinases de superfície, explicando, assim, a perda da capacidade de produção de ácido láctico observada. Os autores demonstraram que as mutações para resistência a fagos e baixa produção de àcido láctico são eventos geneticamente independentes; as mutações para resistência ocorrem com freqüēncia três a cinco vezes menor que aquela para baixa produção de ácido. Por outro lado, como esses mutantes resistentes e lentos são freqüentemente encontrados, o programa de isolamento dos primeiros deve incluir métodos que diferenciem os variantes lentos dos rápidos. Isto pode ser feito por meio de semeadura em meio diferencial "fast-slow" (HUGGINS e SANDINE, 1979 e THUNELL et alie, 1981) ou em leite- citrato-ágar (RICHARDSON ot alii, 1980). De acordo com HULL (1983), os mutantes resistentes a fagos isolados também devem ser ensaiados quanto à capacidade de produção de ácido, por meio de testes que simulem o processamento de queijo, além da verificação de um possível desenvolvimento de aroma e sabores inde sejāveis (PEARCE, 1969 e HULL, 1977 b).

Não é possivel predizer, no entanto, por quanto tempo os mutantes resistentes a fagos irão assim permanecer, sob condições comerciais, podendo esse período variar de um dia a 
um ano. Apesar de alguma instabilidade ser esperada, a perda da resistência tem sido um dos principais problemas, a nível de indüstria (HULL, 1977 a).

\subsection{Plasmédios "Melhoramento Genético}

Muitas I inhagens de estreptococos lácticos possuem plasmídios dos mais variados tamanhos (KLAENHAMMER et alii, 1978; LARSEN e MCKAY, 1978; KEMPLER e MCKAY, 1979 e CHOPIN e LANGELLA, 1982). Apesar do grande nümero de plasmídios que essas linhagens possam apresentar, muitos deles são crípti cos e somente poucos têm suas funções conhecidas (DAVIES e GAS SON, 1981).

A extração e determinação dos plasmídios de estreptococos lácticos foi feita, inicialmente, através de centrifugaçäo, em gradiente de densidade, do DNA marcado radioativamente en clorelo de césio e brometo de etídio (coros et ali, 1974). Alualmente, existem lécnicas mais rápidas e conve nientes ulitizando eletroforese em gel de agarose (MEYeRs et a(í, 1976) que foram adaptadas à deteç̧ão de plasmídios de bacterias lacticas (KLAEnhammer ct ali, 1978). Antes desta deteção, entrelanto, há necessidade de lisar-se a célula para que o DNA possa ser removido. Diversos protocolos relacionados a este ponto foram publicados podendo-se dividi-los em dois grupos: métodos que removem a membrana celular juntamente com - DNA cromossómico por centrifugação (KLAENHAMMER et alie, 1978; 
GASSON E DAVIES, 1980 b; PORTNOY et alii, 1981 e ORBERG e SANDINE, 1984) e métodos envolvendo a desnaturação do onA cromossómico pela elevação do pH (WALSH e McKAY, 1981 e ANDERSON e McKAY, 1983). Estas ültimas técnicas são preferíveis quando se deseja detectar plasmidios com alto peso molecular, ou seja, ultrapassando a 30 Mdal.

A maioria destas técnicas, entretanto, não permi tia um grande nümero de extrações ao mesmo tempo. Assim, foram desenvolvidos protocolos contendo a miniaturização das mesmas podendo-se, dessa forma, realizar até 48 extraçöes de plasmídios num dia de trabalho (LANGELLA, 1982; Yu ct alie, 1982; GASSON, 1983; ANDERSON E MCKAY, 1983; CHOPIN et alii, 1984 e LeBLAivC e LEE, 1934).

A biologia de plasmidios tem se tornado uma ärea importante de investi igação nas bactérias lácticas, pois numero sas caracteristicas fermentativas e metabölicas, de grande ins labilidade cmalguns desses organismos, estão ligadas a genes localizados em plasmidios (McKAY, 1983), tais como: a fermentaçà de lactose (MckAY e BALDWIN, 1984; McKAY et alie, 1976 ; ANDERSON E MCKAY, 1977; KEMPLER e MCKAY, 1979; KUHL et alii, 1979; LEBLANC at ali, 1973; st. MARTIN et alie, 1982 e McKAY, 1982, 1983), de galactose (LeBLANC et alii, 1979; PARK e McKAY, 1982 e CROW (t ali, 1983), de sacarose (GASSON, 1984) e de glicose, manose e xilose (LeBLANC ot alii, 1980); a utilização de citrato (KEMPLER e MCKAY, 1979, 1981); a produção de proteí nases (NOVICK, 1969; MOLSKINESS et alii, 1974; PEARCE ct alie, 
1974; MCKAY e BALDWIN, 1974, 1975; EFSTATHIOU e MCKAY, 1976 ; EXTERKATE, 1976; LARSEN e MCKAY, 19\%8; KLAENHAMMER et alii, 1978; 0TTO et alie, 1982 e MCKAY, 1983) e de nisina e bacteriocinas (KOSAK et alie, 1973; FUCHS et alie, 1975; LeBLANCet alii, 1980; GEIS et alii, 1983, SCHERWITZ et alii, 1983 e DAVEY, 1984); a resistência a sais inorgânicos (EFstATHIOU e MCKAY, 1977) e à nisina (GASSON, 1984 e MCKAY e BALDWIN, 1984) e a produção de substâncias viscosas ou propriedade "filante" (COGAN, 1980; DAVIES e GASSON, 1983 e MCKAY, 1983).

Outras características, jà citadas anteriormente, mediadas por plasmidios incluem: sistemas de restrição e modificação (SANDERS e KLAENHAMMER, 1981 e CHOPIN et alii, 1984) e adsorção de fagos (SANDERS e KLAENHAMMER, 1983 e DE VOS et alie, 1984), conferindo resistência a certos bacteriófagos (MCKAY e BALDWIN, 1984). Com exceção de alguns poucos plasmídios relacionados à fermentaçào de lactose, os quais mostraram- se ser transmissiveis (KEMPLER e HCKAY, 1979; MeKay ct abi, 1980 GASSOA e DAVIES $(1980 \mathrm{c})$, outros ligados à lactose e proteinase que foram transferidos por transdução (MckAy e BALDWIN, 1974, 1976), todos os demais plasmídios associados aos estreptococos läcticos foram identificados por meio de métodos de cura. Estes ültimos incluem a utilização de ivitroso guanidina (McKAY et alie, 1976), de acridina laranja (KEMPLER e MCKAY, 1979), a indução de protoplastização (NovICK et alie, Iÿ0; GASSON, 1983 e CHOPIN et alie, 1984), a utilização de acriflavina (LARSEN e MCKAY, 1978 e GASSON, 1984) e crescimento a elevadas temperaturas (DAVEY e PEARCE, 1980). 
A localização extracromossómica do DNA plasmidial codificando tantas caracteristicas genéticas importantes nas bactérias lácticas faz com que as mesmas sejam herdadas e mantidas de forma muito instável. A evidência cada vez maior da associação de plasmídios com a resistência dos estreptococos lácticos a bacteriōfagos fornece um mecanismo genético que explica o rápido aparecimento de variantes sensíveis nos fermentos lácticos (SANDERS e KLAENHAMMER, 1981, 1983). LAWRENCE (1978) enfatiza que os problemas de fagos nas indūstrias läcticas pode resultar do acümulo desses variantes sensíveis.

As possibilidades crescentes de manipulação destes plasmídios por técnicas de engenharia genética, levando à amplificação de genes plasmidiais por meio de isolamento de mu Lantes contendo um grande nümero de cópias dos mesmos dentro de plasmídios termoestàveis, à combinaçăo dos diferentes locus genéticos para resisténcia a fagos em uma única linhagem e à estabilizaçăo do fenótipo fago-resistente pela integração dos genes de resisténcia a fagos no cromossomo, poderá favorecer a obtençào de linhagens de alta eficiència tecnológica e resistentes a bacteriófagos (MCKAY e BALDWIN, 1984 e MCKAY, 1984 ).

$$
\text { ERICKSON (1980) e DALY e FITZGERALD (1982) já hạ }
$$
viam sugerido que os genes determinantes da produção de diferentes endonucleases de restrição deveriam ser introduzidos nos genomas das linhagens selecionadas, talvez por uma transfe rência de plasmídio, a fim de aumentar sua resistēncia aos bac Leriófagos. 
Dessa forma, o estudo da biologia de plasmídios nos estreptococos lácticos, assim como em outros gêneros de bac térias lácticas, tornou-se um pré-requisito para futuros programas de melhoramento genético. Os processos de conjugação e transdução jà são bem conhecidos (GASSON, 1983), assim como a transformação (KONDO e MCKAY, 1982, 1984 e SIMON et alii, 1985), a transfecção (GEIS, 1982) e a fusão de protoplastos (GASSON, 1980) já foram relatadas em bactérias lácticas.

Manifestaçöes genēticas nos estreptococos läcticos por meio da utilização de transposons também jä foram observadas por CHOPIN et alii (informação pessoal) por meio da in trodução de transposon Tn 916 originärio de S. Gaecalis (FRANKE e CLEWELL, 1980) em S. lactis. Verificaram a ocorrência de inserções cromossömicas de plasmídios, sendo que uma delas con duzia í inativação dos genes de transferência de um plasmídio criptico.

Apesar destes mecanismos de transferência

de genes terem ocasionado um avanço nos estudos de genética e bio logia de plasmidios nestes organismos, o desenvolvimento de um sistema de transformação de plasmídios mais eficiente é vital para os estudos genéticos posteriores e para o uso da tecnolo gia do DiNA recombinante na obtenção de linhagens melhoradas (MCKAY, 1984).

Pelo fato das bactérias lácticas não serem naturalmente passiveis de transformaçã • foram as dificuldades encontradas para melhorar a eficácia deste sistema que mais 
limitaram a aplicação da engenharia genética neste grupo de mi crorganismos (GASSON e DAVIES, 1984 ).

o sucesso da utilização da técnica de transforma ção em estreptococos lácticos foi obtido com a produção e rege neração de protoplastos utilizando-se lisozima (GASSON, 1980), mutanolisina (KONDO e McKAY, 1982) ou uma combinaçäo de amílase e lisozima (OKAMOTO et alii, 1983). A primeira introdução do DNA por transformação de protoplastos em S. lactis, foi obtida por KONDO e McKAY (1982) com rendimentos, entretanto, mui to baixos, aproximadamente 8,5 transformantes/Hg DNA. Posterior mente, os mesmos autores (1984) e SIMON et alii (1985) melhoraram estes rendimentos elevando-os à $10^{3}-10^{4}$ transformantes por micrograma de DNA. Entretanto, por razões ainda inexplicäveis eles são muito inferiores quando utiliza-se DNA recombinante, permitindo clonar-se diretamente em $S$. lactis apenas os genes plasmidiais. Foi desta forma que KONDO e McKAY (1984) clonaram um fragmento do plasmídio pLM 2001 codificando para a assimilação de lactose e que CHOPIN (em publicação) clonou um fragmento do plasmidio plL7 codificando para resistência à ultravioleta um mecanismo de reparo do DNA, alēm de estabilidade ao profago da linhagem hospedeira, ou seja, S. lactis. Atualmente, entretanto, McKAY e CHOPIN (informaçao pessoal), independentemente, já obtiveram resultados de transformação com frequências da ordem de $10^{5}$ e $10^{6}-10^{7}$ transformantes/ug DNA, respectivamente. 
Para aplicar-se as tëcnicas de engenharia genéti ca a um grupo de microrganismos necessita-se, também, de vetores de clonagem adequados, ou seja, pequenos fragmentos de DNA capazes de replicarem-se, ou de integrarem-se em um replicon, portadores de um ou värios genes que codifiquem caracteristicas fáceis a selecionar e dentro dos quais se inserem os genes, os quais deseja-se clonar. Este vetor servirä, em segui da, para introduzir os genes objetivados na linhagem desejada. Vărios tipos de vetores são conhecidos para clonagem em E. Co Pi, entre eles, plasmidios, bacteriófagos e cosmidios. Para os estreptococos, entrelanto, roram descritos apenas plasmídios como vetores, especialmente O PGB $301 \mathrm{em}$ s. sanguis (MACRINA ot alit, 1980 e BEHNKE ot ali i, 1982). Tambëm KONDO e McKAY (1984) utilizaram-se desse mesmo vetor para clonar genes envol vidos no metabolismo de lactose. Jà SIMON et alí(1985) e CHOPIN et alí (em publicação) utilizaram-se do vetor pHV 1301, um deletante de $P A M B_{1}$ encontrado, originalmente em $S$. faecalis (CLEWELl et alii, 1974), codificando ainda, para resistência à eritromicina e presente em nümero de cópias elevado em uma linhagem de B. surtilis.

A clonagem de genes cromossomicos requer, portan to, não somente altos rendimentos de transformação, como passa gem por um hospedeiro interlilediàrio utilizando-se um vetor "na vete". Assim, Kok et alii (1984) desenvolveram o vetor pGKI2, capaz de se replicar em $L$. coli, B. subtilis e nos estreptococos läcticos. Entretanto, de acordo com os caracteres estudados, 
a clonagem dos genes em um hospedeiro intermediário pode ocasionar problemas de expressão e recuperação.

o desenvolvimento das técnicas de clonagem em bactérias lácticas outras que não $S$. lactís está menos avançado. No caso de S. cremoris, por exemplo, SIMON etalie (1985) ob tiveram rendimentos muito baixos, da ordem de 4 transformantes por micrograma de DNA recombinante. Entretanto, a evolução dos rendimentos obtidos com $S$. lactis oferece uma esperança de melhoramento para as outras bactérias lácticas também.

A clonagem em $S$. lactis das principais características de interesse tecnolögico, tais como, assimilação de lactose, produção de protease e mecanismos de resisténcia a fa gos està sendo desenvolvida por várias equipes (DAVIES e GASSon, 1984). Será possível, portanto, objetivar o melhoramento por meio de técnicas de engenharia genética, de linhagens de bactérias lácticas destinadas à utilizaçãonindustrial. Neste c.aso, os vetores de clonagem atuais, constituidos de DNA prove niente de bactéria patogénica e carregando genes de resistência a antibióticos näo seräo autorizados para o melhoramento de linhagens de bactérias lácticas, as quais são consumidas pe lo homem na razäo de $10^{3}$ a $10^{9}$ células por grama de produto láctico. Uma formá de solucionar este problema seria a constru çăo de vetores de clonagem ditos alimentares, possuindo DNA proveniente exclusivamente de bactérias lácticas (SIMON, 1984). 
4. MATERIAL E METODOS

4.1. Microrganismos utilizados

Realizou-se, primeiramente, uma seleção mediante alguns parâmetros tecnológicos, a nível de laboratório, de estreptococos lácticos isolados, em sua maioria, a partir de le i te cru, no Brasil. Estas culturas fazem parte da Coleção de Culturas Läcticas do Institulo de Tecnologia de Alimentos (ITAL), sendo estes experimentos totalmente desenvolvidos naquele Instituto.

Uma parte deste trabalho foi realizada no Laboratoire de Recherches de Technologie Laitière, pertencente ao Institute Wational de la Recherche Agronomique (INRA), em Rennes, na França, o qual dispõe de uma coleção de, aproxima damente, 2.000 culturas lácticas e 150 bacteriófagos, todos mui to bem caracterizados tecnológica e geneticamente. 
Assim, neste trabalho, utilizaram-se as seguintes espécies e respectivas linhagens:

- Streptococcus lactis: 141, 175, 176, 177, 178, $179,187,188,195,206,246,261,265,279,280,281,282$, $283,284,285,286,287,288,289,290,291,292,293,294$, $295,296,297,298,299,300,301,302,303,304,305,306$, $310,313,314,315,316,317,313,319,320,321,322,323$, $324, \quad$ IL 1403, IL 408, IL $6, \quad$ IL I3, IL 414, IL 562, IL 598, IL 823, IL Y29, IL 920 .

- Streptococcus cremoris: 161, 164, 166, 167, $168,169,170,171,172,173,174,189,192,193,196,202$, $203,204,205,207,208,209,210,211,222,224,225,226$, $227,228,229,230,250,252,254,255,257,259,262,263$, $268,269,272,273,307,308,309,311,312,325,326,1 \mathrm{~L} 839$, IL $835, \quad$ IL $10, \quad 1 L 737, \quad$ IL 746.

- Streptococos sp.: 96,97, 101, 104, 105, 113, $180,181,182,183,184,185,186,191,194,233$.

- Streptococcus lactis subsp. diacetylactis: 162, $165,256, \quad$ IL 561

- Bocillus subtilis: MI 119 (MACRINA et alii, 1980).

- Streptococcus sanguis challis: IL 1550. 
As I inhagens IL pertencem à coleção de culturas do INRA. Todas as outras linhagens utilizadas pertencem à Cole ६̧ão de Fermentos Làcticos do ITAL.

As culturas do ITAL foram mantidas inicialmente em leite RSM (item 4.5.3.) tipo Molico, Nestlë, sem coagula६̧ão, em refrigerador a $4^{\circ} \mathrm{C}$. Sua ativação também era feita em le ite RSM, com incubação a $30^{\circ} \mathrm{C}$ durante 18 horas. Posteriormen te, a manutenção de todas as linhagens passou a ser feita em $M 17+$ glicose (item 4.5.2.), sem crescimento, também em refrigerador a $4^{\circ} \mathrm{C}$. Todas as culturas foram estocadas em MI $7+$ glicose +glicerol (item 4.5.6.), juntamente com 2\% de inöculo, com congelação imediata e mantidas em congelador a $-40^{\circ} \mathrm{C}$.

4.2. Plasmidios utilizados

A caracterização dos plasmídios constituintes das culturas selecionadas pertencentes à coleção do ITAL foi reali zada no laboratörio do INRA.

Foram utilizados os seguintes plasmidios:

(a) pHV 1301 - extraido de Bacillus subtilis Ml 119, originário do plasmídio pAMB l e possuindo uma deficiên cia espontânea, obtido apös transformação de cêlulas competentes da mesma cultura. Confere resistência à eritromicina (SIMoN etalie, 1985) e possui o tamanho de $13 \mathrm{~kb}$. 
(b) pVA 856 - extraído de E. coli IL 1505 poss suindo o tamanho de 9,2 kb (MACRINA et alie, 1983).

(c) PVA $749 \Delta$ - extraido de $S$. sanguis challis IL 1550 (MACRINA e.t alie, 1982), conferindo resistência à eritromicina e possuindo o tamanho de 4,9 $\mathrm{kb}$.

(d) PBR 322 - extraído de E. coli (BOLIVAR et alii, 1977), possuindo o tamanho de 4,3 kb.

\subsection{Bacteriófagos utilizados}

Foram utilizados os bacteriófagos $6,8,25,42$, $52,66,67,119,129$ e 188, todos pertencentes à Coleção do IN RA. Os estoques de fagos eram mantidos em $5 \mathrm{ml}$ de tampão. Tris $0,05 \mathrm{M}$ contendo $\mathrm{NaCl} 0,1 \mathrm{M}$ juntamente com glicerol em concentração final de $15 \%$ e conservados sob congelação a $-40^{\circ} \mathrm{C}$.

4.4. Esterilização e nümero de repetiçöes

Todos os meios de cultura e algumas das soluções foram esterilizadas em autoclave a $121^{\circ} \mathrm{C}$ durante 15 minutos a I atm. As demais soluções foram esterilizadas em filtro Sartoryus. A vidraria foi esterilizada em forno pasteur a $140^{\circ} \mathrm{C}$ durante duas horas. 
os experimentos constaram de, pelo menos,

duas

repetições.

4.5. Meios de cultura e s-luções utilizadas

4.5.1. Meio M17 (TERZAGHI e SANDINE, 1975)

Extrato de carne .................. $5 \mathrm{~g}$

Polipeptona ............... $5,0 \mathrm{~g}$

Peptona de soja ............ 5,0 g

Ácido ascörbico ............... $0,5 \mathrm{~g}$

$\beta-g l$ icerofosfato de södio .......19,0 g

Cloreto de magnésio $1 M \ldots \ldots \ldots$ 1, om

Extrato de levedura .......... 2,5g

Lactose ................. $5,0 \mathrm{~g}$

Agua destilada ............... 1,02

Aqueceu-se atë a dissolução, resfriou-se para

$60^{\circ} \mathrm{C}$, ajustou-se o pH para 7,1 e esterilizou-se em autoclave. Quando desejado sölido, adicionaram-se a este meio, l2g de Bac to-ägar Difco por litro e quando desejado semi-sölido, apenas 4,59 desse àgar foram adicionados.

\subsubsection{Meio $M 17+G 1$ icose}

Manceve-se a mesma formulação do meio Ml7 original (item 4.5.1.), substituindo-se o açücar lactose por glicose. Os meios sólidos e semi-sólidos, assim como a esterilizafäo foram semelhantes ao anterior. 
4.5.3. Meio MI7+ Sacarose (KONDO e McKAY, 1982)

Para a resenerarsão de protoplastos, utilizou-se o meio Ml\%̈ (irem 4.5.1.) adicionado de sacarose con concentração final de 0 , b M.

$$
\begin{aligned}
& \text { 4.5.4. Meio M17 a } 10 \% \\
& \text { Polipeptona ................ 0,50g } \\
& \text { Peptona de soja ................ } 0,50 \mathrm{~g} \\
& \text { Extrato de levedura .................. } 0,25 \mathrm{~g} \\
& \text { Extrato de carne ............. 0,50g } \\
& \text { Lactose ...................... } 0,50 \mathrm{~g} \\
& \text { Ácido ascórbico ................. } 0,05 \mathrm{~g} \\
& \text { B-glicerofosfato de sódio ....... 1,9ug } \\
& \mathrm{Mg} \mathrm{SO}+7 \mathrm{H}_{2} \mathrm{O} \text { I } M \ldots \ldots \ldots, \ldots \ldots \ldots \\
& \text { Água destilada .............. 1,0l } \\
& \text { o meio foi distribuído em tubos de ensaio de }
\end{aligned}
$$

$18 \times 180 \mathrm{~mm}$ à razäo de $9,0 \mathrm{ml}$ por tubo e esterilizado como descrito no item 4.4 .

$$
\begin{aligned}
& \text { 4.5.5. Meio de Luria e Bertani (L.B.) (MAN|ATIS } \\
& \text { et alii, 1982) } \\
& \text { Bacto-triptona DIFCO,.......... } 10,0 \mathrm{~g} \\
& \text { Bacto-extrato de levedura DIFCO .... 5, } 5
\end{aligned}
$$

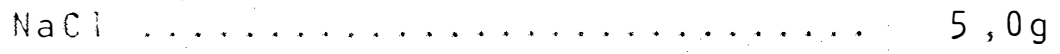

$$
\begin{aligned}
& \text { Agua destilada ................1000ml } \\
& \text { Ajustou-se o pH para 7,3 e esterilizou-se. Quan- }
\end{aligned}
$$$$
\text { do desejado sölido adicionavam-se } 12 \mathrm{~g} \text { de Bacto-ägar DIFCo por }
$$ 
litro. Este meio foi utilizado para o crescimento de Bacillus subtilis MI 119, quando da extração do plasmidio pHV 1301, sob incubação a $37^{\circ} \mathrm{C}$ com agitação.

\subsubsection{Meio Ml7 + Glicose + Glicerol}

Ao meio Ml7 + Giicose (item 4.5.2.) adicionou-se glicerol com concentração final de 15\%. Este meio foi utilizado para manutenção do estoque de culturas sob forma congelada a $-40^{\circ} \mathrm{C}$.

4.5.7. Solução de RINGER (HARRIGAN e MCCANCE, 1976)

Cloreto de sódio $\ldots \ldots \ldots \ldots \ldots \ldots 2,25 \mathrm{~g}$

Cloreto de potássio ............... $10 \mathrm{~g}$

Cloreto de cálcio hidratado ........ $0,12 \mathrm{~g}$

Bicarbonato de södio .............. 0,05g

Agua destilada ................ 1,0l

Dissolveram-se os sais na água, distribuiu-se a solução em frascos de lo0me e esterilizou-se.

4.5.8. Leite RSM ("reconstituted sterile milk") para manutenção

Leire desnatado $\ldots \ldots \ldots \ldots \ldots \ldots \ldots \ldots \ldots$ 14,0 g

Agua destilada ................ 100m

Este meio foi distribuido em tubos de ensaio, na quantidade de 5 ml e esterilizado, sendo usado apenas para a má nutenção da coleção de culturas em refrigerador. 


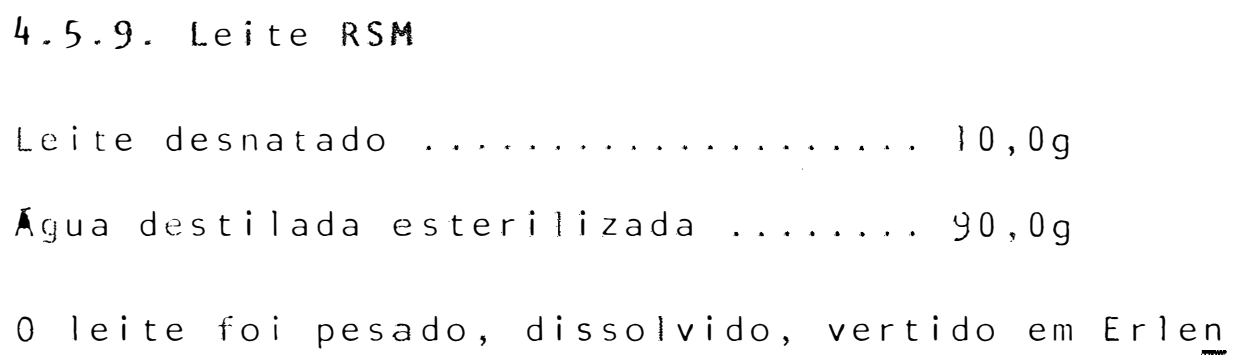
meyer e colocado durante 20 minutos em ägua em ebulição. Todo o material aqui usado foi esterilizado quando se necessitava do leite apenas pasteurizado. Nos casos onde se utilizou o le te RSM esterilizado, pode-se encontrar a devida notificação na metodologia.

\subsubsection{Tampão de Lise para Extração Preparativa de Plasmídios (MANIATIS et alii, 1982)}

Foi preparada uma soluçào (A) constituída de gli cina $0,1 M$ em $N a C l 0,1 M$. Preparou-se, também uma solução (B) constituida de tampào NaOH O,I M. Misturou-se uma determinada quantidade (X ml) da soluçào A e outra (100-X me) da solução B, adicionando, ainda, $4 \%$ de SDS (Dodecil Sulfato de Södio). Es tocou-se o tampão de lise em congelador. Para se efetuar a extração de plasmídios utilizou-se um tampão de lise com pH de 12,8, que corresponde a uma quantidade inicial da solução A igual a $24,2 \mathrm{ml}$.

\footnotetext{
4.5.11. Tampão de Lise (TL) (PORTnOr et alii, 1981)

SOS 4\% em TE na quantidade desejada, pH 12,8. 0is
} tribuiu-se a solução em tubos de ensaio e estocou-se em congelador. Quando necessàrio, era descongelada em banho-maria a $37^{\circ} \mathrm{C}$. 
4.5.12. Tampão paralisador de lise (SB) (MANIATIS et alie, 1982)

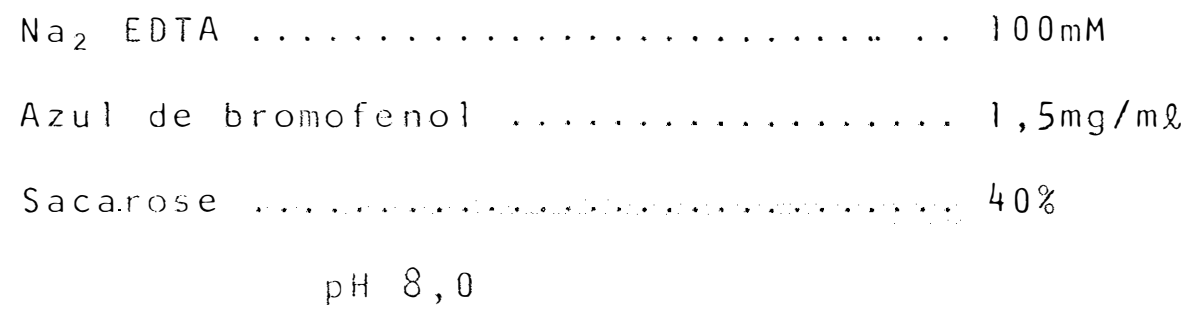

4.5.13. Tampão para Protoplastos (TP) (GASSON, 1980) 
4.5.17. TERNASE (MANIATIS et alii, 1982)

$\operatorname{Tris} \ldots \ldots \ldots \ldots \ldots \ldots \ldots \ldots \ldots \ldots$

$\mathrm{Na}_{2}$ EDTA ................. I $\mathrm{mM}$

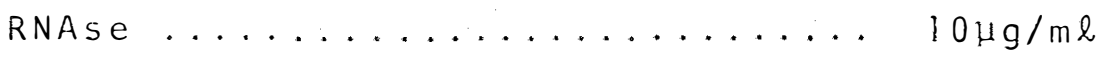

$$
\mathrm{pH} 7,5
$$

Aqueceu-se a solução a $100^{\circ} \mathrm{C}$ durante 10 min, distribuiu-se em tubos Eppendorf e estocou-se em congelador. Quan do necessārio, descongelou-se à temperatura ambiente.

4.5.18. Tampão para extração de DNA cromossômico (MANIATIS et alii, 1982)

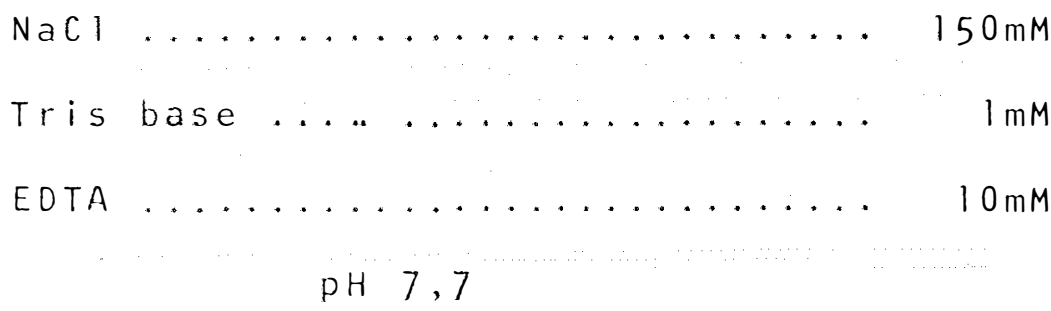

4.5.19. Sacarose-Maleato-Magnësio (SMM) (KONDO e McKAY,1982) Sacarose ................... $0,5 \mathrm{M}$ Maleato de södio............. $20 \mathrm{mM}$

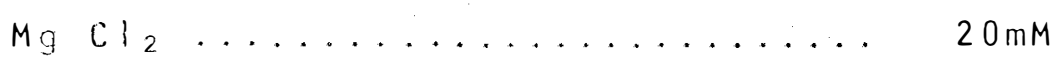
$\mathrm{pH} 6,5$

4.5.20. \{SMM $\times 2($ KONDO e MCKAY, 1982) Sacarose ................ I $M$ Maleato de södio............ $40 \mathrm{mM}$ $\mathrm{MgCl}, \ldots \ldots \ldots \ldots \ldots \ldots \ldots \ldots \ldots$ $\mathrm{pH} 6,5$ 
4.5.21. SMM + MI7 (KONDO e MCKAY, 1982)

Elaborado a partir de 1 volume de $\{$ SMM $\} \times 2$ juntamente com I volume de $\{M \mid 7+(G 1 \mathrm{i}) \times 4\}$.

4.5.22. PEG 40\% (KONDO E MCKAY, 1982)

PEG $3000 \ldots \ldots \ldots \ldots \ldots \ldots$ 4...........

$\{S M M\} \times 2 \ldots \ldots \ldots \ldots \ldots \ldots$

Água destilada q.s.p. .......... $100 \mathrm{m \ell}$

4.5.23. Tampão para digestão com enzima de restrição (MANIATIS et alii, 1982)

- Tampão de baixa concentração salina ("Low-Salt buffer")

$\operatorname{Tris}-\mathrm{HCl} \ldots \ldots \ldots \ldots 10 \ldots \ldots$

$\mathrm{MgCl}_{2} \ldots \ldots \ldots \ldots \ldots \ldots \ldots \ldots \ldots$

oitiotreitol ............. $1 \mathrm{mM}$

$\mathrm{pH} 7,5$

4.5.24. Tampäo para eletroforese Tris-Borato

Tris base ................ 54,0g

Acido börico .................27,5g

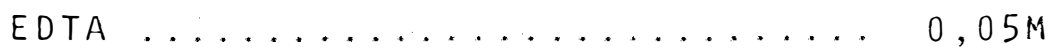

$\mathrm{pH} 8,0$

0 tampão assim preparado apresenta uma concentra ção de 5 vezes. Para ser utilizado fazia-se uma diluição de 1:10. 
4.5.25. Tampão de ligação (MANIATIS et alii, 1982)

Tris-HCl .................... $660 \mathrm{mM}$

$\operatorname{MgCl} 2 \ldots \ldots \ldots \ldots \ldots \ldots \ldots \ldots \ldots$

Ditiotreitol .............. $50 \mathrm{mM}$

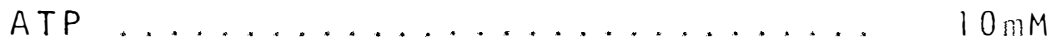

$\mathrm{pH} 7,5$

Ao extrato plasmidial linear adicionavam-se 1/10 do tampão de ligação e l unidade de $T_{4}$ DNA ligase (Boehringer) por micrograma de DNA. A mistura era incubada durante 18 horas a $19^{\circ} \mathrm{C}$.

4.6. Capacidade de coagulaçäo do leite RSH a $23^{\circ} \mathrm{C}$ durante 18 horas (HEAP e LAWRENCE, 1981)

Em tubos contendo $10 \mathrm{ml}$ de leite RSM esterilizado inoculou-se $1 \%$ das culturas a serem testadas, previamente ativadas durante 3 dias, incubando-se, a seguir, a $23^{\circ} \mathrm{C}$ durante 18 horas, após as quais selecionaram-se as que haviam coagulado.

4.7. Teste de sensibilidade à temperatura (HEAP e LAWRENCE, $1981)$

As culturas selecionadas de acordo com o procedi mento descrito no item anterior foram inoculadas na quantidade de $0,1 \mathrm{ml}$ em tubos contendo $9,7 \mathrm{ml}$ de leite RSM estëril e $0,2 \mathrm{ml}$ de $\beta$-glicerofosfato de södio. 0 inóculo foi padronizado com EDTA, pH 12,0, obtendo-se a densidade óptica a $410 \mathrm{~nm}$. Apōs incubação a $23^{\circ} \mathrm{C}$ durante 18 horas, mediu-se o pH das culturas, 
selecionando-se as que apresentaram um pH mais baixo.

As culturas assim selecionadas foram inoculadas $(2 \%)$ em tubos contendo $9,8 \mathrm{ml}$ de leite RSM mantidos em banho de gelo. Estes tubos foram, então, transferidos para banho-maria a $30^{\circ} \mathrm{C}$ e mantidos nesta temperatura durante $90 \mathrm{minutos}$. Após esse tempo, foram transferidos para temperatura de $38^{\circ} \mathrm{C}$ e manLidos durante 4 horas, sendo, entäo, resfriados rapidamente em banho de gelo e feita a leitura do pH.

4.8. Método de someaduna para determinação do título de bactoriofagos (ADAMS, 1950)

Em um tubo de ensaio esterilizado inocularam-se $0,2 \mathrm{ml}$ das culturas juntamente com $0,1 \mathrm{ml}$ do soro contendo fagos com e sem diluiçöes e $0,05 m \ell$ de $\mathrm{CaCl}_{2}$ IM. Apös incubação dessa mistura durante $10 \mathrm{minutos}$ a $30^{\circ} \mathrm{C}$, adicionaram-se $3,0 \mathrm{ml}$ de $\mathrm{Ml} 7 \mathrm{se}$ mi-sólido, agitou-se e verteu-se em placas de petri contendo $M 17+G 1$ i sólido adicionado de Ime de $\mathrm{CaCl}_{2}$ IM para cada $100 \mathrm{ml}$ de meio.

As placas com as duplas camadas de meio foram in cubadas a $30^{\circ} \mathrm{C}$ e após 4 a 5 horas de incubação já se podia fazer a primeira contagem das placas liticas; a contagem final foi feita após 18 horas.

4.9. Determinaçao da Ciberaçao espontanea de bacteriōjagos A técnica seguida neste caso foi adaptada a partir daquelas propostas por HARRIGAN e MCCANCE (1976) e HEAP e 
LAWRENCE (1981). Essa técnica consistiu, basicamente, na inocu lação de $0,2 \mathrm{ml}$ de cultura ativa em 2 tubos contendo $9,8 \mathrm{ml}$ (tubos-controle) e 2 com $9,7 m \ell$ (tubos-teste) de leite RSM. Esse meio assim preparado foi incubado a $30^{\circ} \mathrm{C}$ durante 90 minutos e transferido para $38^{\circ} \mathrm{C}$ durante 4 horas, sendo, entäo, resfriado em banho de gelo e determinado o pH.

Parte da cultura contida em um dos tubos com 9,7me foi transferida, antes da determinação da acidez, para um tubo de centrífuga estéril, ao qual adicionou-se 0,05ml de ácido láctico puro esterilizado. Após centrifugção a 3.000 r.p.m. durante 3 min, o sobrenadante foi recuperado em um tubo de ensaio estëril e guardado em refrigerador a $4^{\circ} \mathrm{C}$.

Do segundo dia em diante inocularam-se, nos tubos-teste, $(9,7 \mathrm{ml}), 0,2 \mathrm{ml}$ de cultura ativa e $0,1 \mathrm{ml}$ do soro coletado no dia anterior. Este procedimento foi repetido durante dez dias consecutivos, considerando-se aprovada, a cultura que não demonstrou, pela queda na acidificação, quando comparada com seu controle, uma multiplicação de fagos apös um mínimo de sete repetições.

4.10. Verificação de lisogenia através de indução com luz ultravioleta (U.V.)

Para indução de profagos, as bactérias lácticas foram irradiadas com luz U.V. (comprimento de onda $=247 \mathrm{~nm}$ ) se guindo-se metodologia proposta por CHOPIN et alii (1985), a qual serā descrita a seguir. 
As bactérias crescidas em $20 \mathrm{ml}$ de MI7, a $30^{\circ} \mathrm{C}$ dü rante $90 \mathrm{~min}$, ou seja, no início da fase exponencial de cresci. mento (determinada a partir de curva de crescimento feita ante riormente), foram centrifugadas a 5.000 r.p.m. durante $10 \mathrm{~min}$ e ressuspendidas em mesmo volume de solução de Ringer 1:4. Ver teram-se $15 \mathrm{~m} \ell$ dessa suspensão em uma placa de Petri contendo um agitador imantado, ambos estēreis. $0 s 5 \mathrm{ml}$ restantes foram utilizados como controle. Irradiou-se a suspensão, mantida sob constante agitação, por meio de incidência de luz U.V., durante 4 e 12 segundos, resultando numa dose de irradiação de $20 \mathrm{~J} . \bar{m}^{2}$ ou $60 \mathrm{~J} . \overline{\mathrm{m}}^{2}$, respectivamente, dependendo da linhagem. A intensidade da lâmpada U.V. foi medida por um radiōmetro Black- Ray UVX (Ultraviolet products Inc.).

Apōs irradiação, pipetaram-se $10 \mathrm{ml}$ da suspensão em um tubo contendo lome de Ml 7 + Gli dupla concentração. Deste tubo, tomaram-se $10 \mathrm{ml}$ e incubou-se a $30^{\circ} \mathrm{C}$, observando se havia clareamento do meio. Em caso de clareamento, o meio era filtrado, diluído e testado pelo método de gotas contra todas as culturas làcticas brasileiras e alguns estreptococos lácticos sensiveis tes:adores, pertencentes à coleção do INRA. Também o tubo contendo o meio controle foi filtrado e ensaiado contra as mesmas culturas.

o crescimento e lise das células também foi acom panhado por meio de espectrofotómetro (Bonet, Maury, Jouan, Fran ce), obtendo-se valores de densidade öptica das amostras irradiadas e não irradiadas, durante incubação a $30^{\circ} \mathrm{C}$. 
4.11. Titulação de bacteriōbagos pela técnica de gotas (cho PIN et alii, 1976)

Placas de Petri contendo Ml7 + Gli sölido foram inundadas com $1,5 \mathrm{ml}$ da cultura crescida durante 18 horas a $30^{\circ} \mathrm{C}$, sendo colocadas, abertas, em estufa a $37^{\circ} \mathrm{C} \mathrm{com}$ ventilação, durante 30 minutos para secagem.

Gotas das diluições convenientes em Ml7 $10 \%$ dos fagos a serem testados foram depositadas sobre as placas de Pe tri, com o auxílio de uma pipeta Pasteur. Apōs incubação por uma noite, a $30^{\circ} \mathrm{C}$, contaram-se as placas de lise constantes em cada gota depositada. Cada mililitro de Ml7 $10 \%$ contém aproximadamente 38 gotas, assim, a leitura de lise foi feita multiplicando-se o nümero de placas por 38 .

4.12. Preparação de estoques com alto tétulo de fagos (REYROLLE et alie, 1982)

Frascos contendo $100 \mathrm{~m} \ell$ de $M 17+$ Gli foram inoculados com 2\% da cultura a ser estudada. Após incubação durante 2 horas a $30^{\circ} \mathrm{C}$, adicionaram-se $10^{6} \mathrm{uFP} / \mathrm{ml}$ (unidade formadora de placa) do fago a ser propagado, juntamente com lme de CaCl2 IM, continuando a incubação a $30^{\circ} \mathrm{C}$. Apōs estabelecimento de lise, verificada pelo clareamento da solução, a mesma foi filtrada em filtro Sartoryus.

Preparam-se estoques dos fagos virulentos 6 (IL 6), $3(1 \mathrm{~L} 10), 25(1 \mathrm{~L} \mid 3), 42(1 \mathrm{~L} 414), 52(1 \mathrm{~L} 598), 66(1 \mathrm{~L} 561), 67$ $(1 \mathrm{~L} 562), \quad 119(1 \mathrm{~L} 737), 129(1 \mathrm{~L} 746)$ e $188(1 \mathrm{~L} 823)$. 
4.13. Concentraçāo de bagos por polietileno-glicol (JARVIS, 1978)

Após estabelecimento de lise nos frascos contendo $100 \mathrm{ml}$ de $M 17 \mathrm{gli}+1 \mathrm{ml}$ de $\mathrm{CaCl}_{2} 1 \mathrm{M}+2 \%$ de cultura láctica, como descrito no item 4.12, pode-se também, ao invés de filtrar, centrifugar a 13.000 r.p.m, durante 10 min, com refrigeração. Ao sobrenadante recuperado adicionou-se NaCl 5M, de for ma a obter uma concentração final de 0,5M, juntamente com polietileno-glicol 4.000 a dose de $10 \%(p / v)$. Deixou-se essa mís tura durante uma noite a $4^{\circ} \mathrm{C}$. Centrifugou-se a seguir, a 10.000 r.p.m., durante 10 min, ressuspendendo-se os fagos em $5 \mathrm{ml}$ de tampão Tris $0,05 \mathrm{M}$ contendo NaCl $0,1 \mathrm{M}$.

Dialisou-se contra esse tampão durante todo um dia, a $4^{\circ} \mathrm{C}$. Esterilizou-se, após, por filtração.

t.1t. Exthacade de plasmidios

4.14.1. Micro-método para a determinação rápida de perfis plasmidiais (PORTNOY et alie, 1981)

Alficuotas de 1, 3 ml de culturas crescidas durante 6 horas a $30^{\circ} \mathrm{C}$, em M17, foran centrif ugadas a $4.500 \mathrm{r.p.m}$. durante 5 minutos, à temperatura ambiente, e as células ressuspendi das em $800 \mu l$ de TE. Essa suspensão celular foi novamente centrifugada a $5.000 \mathrm{r.p.m}$. durante 5 minutos e as células ressuspendidas em 150 He de TE + 25\% de sacarose (TES). 150 Hl de uma solução de lisozima a $10 \mathrm{mg} / \mathrm{m \ell}$ em TES, preparada anteriormente, 
foram adicionados seguindo-se incubaçäo em banho-maria a $37^{\circ} \mathrm{C}$ durante 10 min.

os protoplastos assim obtidos foram centrifugados a 4.000 r.p.m. durante 10 minutos e recuperados em loul de TES e 600 le de tampão de lise (item 4.5.11.), que provocava, assim, uma desnaturaço do DNA. Para uma ação completa do tampão de lise, os tubos foram incubados em banho-maria a $37^{\circ} \mathrm{C}$ du rante $20 \mathrm{~min}$. A adiçäo de $30 \mu \ell$ de Tris-HCl 2M, pH 7,0, proporcionava uma baixa de pH entre 7,5 e 8,5 , ocasionando uma renaturaçäo do DNA plasmidial. A seguir, a adiçäo de $160 \mu \ell$ de NaCl $5 \mathrm{M}$ provocava o aparcoimento de um precipitado branco de Sos jun tamente com os residuos de membrana e o DNA cromossomico. Os tubos foram colocados a $4^{\circ} \mathrm{C}$ durante, pelo menos, uma hora, sen do centrifugados apos, durante 30 minc a $4^{\circ} \mathrm{C}$ a $13.000 \mathrm{r} . \mathrm{p} . \mathrm{m}$.

Retiraram-se 500 He do sobrenadante contendo o DivA plasmidial, transferindo-se para um novo tubo Eppendorf. Adicionaram-se-lhes $200 \mu$ de acetato de södio 3 M e $700 \mu$ de etanol absoluto deixandorse agir 30 min à temperatura ambiente. Isto provocava a precipitação do DNA plasmidial. Após centrifu gaçäo dos lubos durante 20 min a $4^{\circ} \mathrm{C}$ a $13.00 u$ r.p.m., secava-se- Thes cuidadosamente e recuperava-se-Ihes os precipitadosem $60 \mu$ l de TERNase. 30 lu dosso extrato forain submetidos à eletroforese.

4.14.2. Extraçäo preparativa e purificação de plasmidios (PORTNOY et alii, 1981)

Este método foi utilizado para preparar extratos de plasmídios a partir de 1,52 de cultura. 
A cultura crescida em Ml7 + glicose durante 6 ho ras a $30^{\circ} \mathrm{C}$ foi centrifugada durante $10 \mathrm{~min}$ a $5.500 \mathrm{r} . \mathrm{p} . \mathrm{m}$. e as células ressuspendidas em TE sendo, apös, centrifugadas durante 10 min a 6.000 r.p.m. e ressuspendidas em TES. Foram adicionados $30 \mathrm{ml}$ de TES contendo $10 \mathrm{mg} / \mathrm{m} \ell$ de lisozima, deixando-se agir em banho-maria a $37^{\circ} \mathrm{C}$ durante $10 \mathrm{~min}$. Os protoplastos assim obtidos foram recuperados por centrifugação durante 10 min a $5.00 u$ r.p.m. e os precipitadosrecuperados em $8 \mathrm{ml}$ de TES. Adicionaram-se $125 \mathrm{~m} \ell$ de tampão de lise (item 4.5.10.) deixando-se agir durante $20 \mathrm{~min}$ a $37^{\circ} \mathrm{C}$. 0 pH foi ajustado a 7,5-8,5 por adição de $25 \mathrm{ml}$ de Tris-HCl 2M, pH 7,0. A seguir, adicionaram-se $40 \mathrm{ml}$ de $\mathrm{NaCl} 5 \mathrm{M}$ incubando-se a $4^{\circ} \mathrm{C}$ por, no minimo, uma hora.

Eliminou-se o precipitado formado por centrifuga çăo durante 30 min a 14.000 r.p.m. O sobrenadante foi recuperado, anotando-se o seu volume: $x$ ml. Adicionaram-se $2 \times / 5 m l$ de acetato de sódio $3 M$ centrifugando-se, a seguir, durante $30 \mathrm{~min}$ a 14.000 r.p.m. Adicionaran-se $7 \times / 5 m \ell$ de etanol absoluto ao sobrenadante deixando-se 30 min à temperatura ambiente. Centrifu gou-se durante 15 min a $4^{\circ} \mathrm{C}$ a 14.000 r.p.m.

os recipitados obtidos foram cuidadosamente secados antes de ser ressuspendidos em solução com 3,5ml de TERNase. Esses extratos foram transferidos para tubos de vidro, adicionando-se-1hes 3,5me de cloroformio: alcool isoamílico (24:1) e emulsionando-se-lhes por agitação suave. Essa emulsão foi centrifugada durante 10 min a 4.500 r.p.m. e a fase superior foi 
recuperada com ajuda de uma pipeta Pasteur. O DNA foi precipitado pela adição de $0,35 \mathrm{ml}$ de acetato de södio $3 M, 7 \mathrm{ml}$ de etanol absoluto e conservado à temperatura ambiente durante 30 min. Esse precipitado foi centrifugado durante 20 min a 12.000 r.p.m. Ressuspenderam-se os precipitados em $3,5 \mathrm{ml}$ de TE, adicionando-se $3,5 \mathrm{~g}$ de CsCl e $400 \mu l$ de uma solução a $10 \mathrm{mg} / \mathrm{ml}$ de brometo de etídio (BET), sendo centrifugados, a seguir, durante $40 \mathrm{~h}$ à temperatura ambiente a 103.100 r.p.m.

Por meio de incidència de luz ultravioleta (360nm) duas bandas eram visíveis. Os plasmidios foram recuperados a partir da banda inferior por punção lateral do tubo com uma se ringa. Os extratos foram emulsionados em l volume de butanol- 2 saturado com água. As duas fases formadas foram separadas por centrifugação a $5.50 u$ r.p.m. durante 3 min. Essa extração foi repetida até o desaparecimento total da cor rosa e sendo feita ainda uma vez suplementar.

o extrato final foi dialisado contra l litro de TE, o qual foi mudado três vezes, sendo a primeira diälise rea lizada à temperatura ambiente e as seguintes a $4^{\circ} \mathrm{C}$. 0 extrato foi conservado à temperatura de $4^{\circ} \mathrm{C}$.

4.15. Eletroforese em Gel de Agarose (MEYERS et alii, 1976)

Utilizou-se a técnica de eletroforese em gel de agarose para determinar o nümero e a massa molecular de plasmídios para avaliar a concentração de um extrato plasmidial e cromossômico. 
A eletroforese foi realizada em tampão Tris-Borato (item 4.5.24.). A concentração de agarose utilizada foi de $0,5 \%$ para as eletroforeses horizontais e de $1 \%$ para as eletroforeses verticais.

A agarose (High Gelling Temperature Agarose Seakem) foi misturada a $100 m \ell$ do tampão de eletroforese, sendo fundida por meio de ebulição em forno de microondas durante $5 \mathrm{~min}$. As amostras (geralmente $30 \mu \ell$ ) foram adicionadas de $5 \mu l$ de tampão paralisador de lise (item 4.5.12.) e distribuidas nos poços do gel. A eletroforese foi efetuada por uma solução de bro meto de etidio a $0,5 \mathrm{~g} / \mathrm{ml}$ e examinados em luz UV $(300 \mathrm{~nm})$.

Os géis foram fotografados sob luz UV (Transillu minateur UV products), utilizando-se um aparelho Polaroid MP 3 , munido de um filtro laranja e de um filtro UV, alëm de um filme Polaroid 667.

4.16. Eletroforese bidimensional (HINTERMANN et alii, 1981)

Esta técnica foi utilizada a fim de se distinguir as três formas possíveis sob as quais um mesmo plasmídio pode se apresentar em gel de agarose.

Apös uma primeira eletroforese (item 4.15.), coIoração com BET e fotografia do gel, a pista contendo as diferentes bandas plasmidiais a serem identificadas foi recortada e irradiada durante quatro minutos, a $30 \mathrm{~cm}$ de distäncia de uma 1 ampada U.V. $(254 \mathrm{~nm})$ com intensidade de $500 \mathrm{erg} / \mathrm{mm}^{2}$. Essa irradiação, em presença de BET, ocasionava cortes nas formas 
super-espiralada (CCC), sendo que uma parte delas tornava-se re I axada (OC), enquanto uma outra parte continuava CCC. As formas OC, se presentes inicialmente, näo seriam modificadas.

A pista irradiada foi, em seguida, inclusa em um novo gel de agarose, o qual foi submetido a uma nova eletroforese, em direção perpendicular. Após esta segunda eletroforese, procedeu-se a uma nova coloração com BET e, após fotografar-se o gel, poder-se-ia distinguir uma sucessão de triângulos formados: as formas oc inicialmente presentes, as oc forma das apös a irradiação e as CCC que subsistiram após a irradiaçäo. Este teste adnite que as formas fora dos triángulos seriam as formas lineares ( $L$ ) de ONA plasmidial e cromossómico.

4.17. Estimativa do peso molecular dos plasmedios a partin de gee de eletroborese em agarose

Os pesos moleculares (PM) dos plasmídios presentes nos extratos foram estimados por cálculo, utilizando-se a observação de MEYERS et alie (1976) segundo a qual, o logaritmo da migração relativa de uma banda de plasmídios é uma função linear do logaritro do seu PM.

Incluiu-se no gel, juntamente com o extrato pla $\underline{s}$ midial de S. cremoris IL 839, o extrato plasmidial de S. Lactis IL 1437, e os plasmídios pBR 322, pVA $749 \triangle$ e pVA 856, cujos pe sos moleculares eram conhecidos.

os pesos moleculares dos plasmídios são expressos em megadàltons (Mdal = $10^{6}$ dàltons). 
4.18. Titulação do DNA plasmidial e cromossômico (MANIATIS et alie, 1982)

A amostra a ser determinada, assim como uma gama de diluição de uma preparação do fago $\lambda$ a $50 \mathrm{mg} / \mathrm{ml}$ (Boehringer) foram submetidas a uma eletroforese em gel de agarose $0,5 \%$ pre parado como descrito anteriormente, comparando-se, visualmente, a intensidade de fluorescencia do DNA plasmidial ou cromos sômico com aquela da gama etalonada estimando-se, assim, a quan tidade de DNA existente na amostra.

4.19. Recuperaçäo do DNA plasmidial a partir do gel de agarose (MANIATIS et alie, 1982)

Apös extração preparativa dos plasmídios de $S$. cremoris IL 839, efetuou-se a eletroforese vertical em gel de agarose durante uma noite, a $30 \mathrm{~V}$. Coloriu-se o gel com BET e observou-se rapidamente sob luz U.V., a fim de localizar a ban da correspondente ao plasmidio pIL 21. Essa banda foi recortada e colocada dentro de um saco de diälise contendo tampão Tris Borato diluido a $1: 2$ e, em seguida, dentro de um recipiente pá ra eletroforese contendo o mesmo tampão. Fez-se passar corrente elétrica de loov durante 3 horas, a fim de eletroeluir o DNA do gel para as paredes internas do saco de diálise. Reverteu-se, a seguir, a polaridade da corrente durante 5 min para liberar O DNA das paredes do mesmo.

Abriu-se o saco e recuperou-se todo o tampão ali presente dentro de um tubo de centrífuga, lavando-o duas vezes, 
com o mesmo tampão. Precipitou-se o ONA plasmidial, de acordo com método descrito no item 4.14.2. e realizou-se uma eletroforese de controle juntamente com o extrato plasmidial total, para confirmar se o DNA recuperado correspondia, realmente, ao plasmidio plL 21.

4.20. Obtencae regeneraca de notoplastos (GASSON, 1983)

100 me da cultura de S. cremoris IL 839 crescida em MI7 durante 16 horas a $30^{\circ} \mathrm{C}$ foram centrifugados durante 10 min a 6.800 r.p.m. à temperatura ambiente. Ressuspenderam-se as células em lo0me de àgua destilada, procedendo-se a uma nova centrifugação a 7.400 r.p.m. durante 10 min, tambēm à temperatura ambiente. Oprecipitado celular foi recuperado em lome de tampão para protoplastos (TP), sendo seguido o procedimento descrito abai $\times$.

Em um mesmo tubo foram misturados $5 \mathrm{ml}$ da suspensão celular acima (C) juntamente com $5 \mathrm{ml}$ de TP. Em um segundo tubo, foram misturados $5 \mathrm{ml}$ da mesma suspensão juntamente com $5 m 2$ de $T P+2 m g$ de lisozima por mililitro (P). Ambos os tubos foram incubados a $37^{\circ} \mathrm{C}$ durante 3 horas, sendo feitos exames em contraste de fase ao microscópio após 1,2 e 3 horas de incuba ção. Após verificação da ocorrência de protoplastos, efetuou-se centrifugação a 4.250 r.p.m. durante $30 \mathrm{~min}$. Os precipitados de (C) e de (P) foram ressuspendidos em loml de TP, repetindo-se, a seguir, uma centrifugação nas mesmas condições. Os precipitados 
de (C) e (P) foram recuperados em loml de TP e foram feitas di I uições decimais aproximadas dos mesmos, tambëm em TP, semeando-as em Ml7 Gli e Ml7 Gii + Sacarose, em placas de Petri.

Todas as placas contendo as diferentes diluições e meios foram incubadas a $30^{\circ} \mathrm{C}$. Efetuou-se a marcação das colô nias que cresceram apös 5 e 7 dias de incubação. Foram transfe ridas por repicagem para MI7 GIi 100 das colónias crescidas após 7 dias nas placas (P) que continham MI7 Gli + Sacarose.

Os protoplastos das 100 colónias assim obtidas foram submetidos a uma micro-extração de plasmídios (item 4. 14.1.), a fim de verificar se haviam perdido os plasmídios contidos na linhagem original.

\subsection{Preparaçäo de DNA plasmidial sob forma linear}

Em um tubo Eppendorf foram pipetados looul de - Na plasmidial com concentraçăo de $50 \mu g / m \ell, 10 \mu l$ de tampão de restrição apropriado e um volume adequado da enzima de restrição Hpa $1 /$ (Boehringer). Após incubação durante duas horas à temperatura de $37^{\circ} \mathrm{C}$ efetuou-se uma purificação do DNA através de passagens sucessivas por fenol, fenol + cloroförmio: älcool isoamílico e somerte älcool isoamílico, de acordo com metodolo gia descrita por MANIATIS ct alie, 1982. Adicionaram-se $44 \mu \ell$ de acetato de södio $3 \mathrm{M}$ e $970 \mu \mathrm{l}$ de etanol a $4^{\circ} \mathrm{C}$. Incubou-se durante 30 minutos a $-20^{\circ} \mathrm{C}$ e centrifugou-se durante 20 minutos a 13.000 r.p.m. Oprecipitado assim obtido foi seco cuidadosamente e ressuspendido no volume desejado de TE autoclavado. 
4.22. Extraçäo preparativa de DNA cromossomico (HARRIS-WARRICK et abii, 1975)

$500 \mathrm{~m}$ de cultura crescida em MI 7 + Gli durante 6 horas a $30^{\circ} \mathrm{C}$ foram centrifugados a 5.500 r.p.m. durante 10 minutos à temperatura ambiente. O precipitado celular foi ressuspendido em $10 \mathrm{~m}$ de tampäo (i tem 4.5.18.), sendo adicionados $10 \mathrm{mg} / \mathrm{m \ell}$ de 1 isozima. Após incubação a $37^{\circ} \mathrm{C}$, durante 10 minutos, adicionaram-se $2 \mathrm{ml}$ de SDS $25 \%$ agitando-se cuidadosamente. Incubou-se em banho-maria a $60^{\circ} \mathrm{C}$ durante 15 minutos adicionando-se, a seguir, lomg de pronase por mililitro. Procedeu-se a nova incubação a $50^{\circ} \mathrm{C}$ a të se observar o clareamento da solução, resfriando-se, a seguir, em gelo. Agitou-se essa mistura em vortex à velocidade mäxima durante 30 segundos, procedendo-se, em seguida, a uma desproteinização com fenol e älcool iso amílico e centrifugação a 5.000 r.p.m. durante 10 minutos. Ao sobrenadante recuperado adicionaram-se $3,5 \mathrm{mg} / \mathrm{ml}$ de cloreto de césio e $400 \mu l$ de brometo de etídio (BET) a $10 \mathrm{mg} / \mathrm{ml}$, procedendo-se, a seguir, como descrito no item 4.14.2.

4.23. Digestäo parciar do DNA cromossomico por endonucleases de restrição

Em tubos Eppenderf foram adicionados $4 \mu l$ de uma solução de ONA crcmossômico de 1 L 839, possuindo a concentração de $400 \mu g$ por mililitro, 96ul do tampão de restrição "low-salt" (item 4.5.23.) e 5Hl de diversas diluições da enzima Hpa 11. Essas diluiçōes continham 2, 1, 0,5, 0,25, 0,12,0,06, 0,03 e 0 U.1. de Hpa 11. 
Os tubos foram incubados durante 1 hora a $37^{\circ} \mathrm{C}$, após a qual retiravam-se $2 \mu \ell$, adicionavam-se $20 \mu l$ de TE e $5 \mu l$ de SB (item 4.5.12.) e procedia-se à eletroforese horizontal em gel de agarose (item 4.15.) durante 6 horas a $30 \mathrm{~V}$, juntamente com o DNA do fago $\lambda$ digerido por H'nd 111 (MURRAY e MURRAY, 1975). Dessa forma, determinava-se qual a quantidade ideal de Hpa 11 que efetuase a digestão parcial do cromossomo.

Para se obter uma grande quantidade de cromossomo parcialmente digerido, o procedimento seguido era o mesmo, alterando-se, apenas, as quantidades iniciais do DNA, assim co mo dos demais reagentes.

\subsection{Centrifugaçäo em gradiente de sacarose}

O DNA cromossōmico obtido após digestão parcial com Hpa 11 era purificado por fenol:cloroförmio, de acordo com metodologia descrita por MANIATIS et alie (1982). Recuperava- se O DNA precipitado em $500 \mu l$ de TE, aquecia-se a $60^{\circ} \mathrm{C}$ durante $10 \mathrm{~min}$, resfriava-se a $20^{\circ} \mathrm{C}$ e colocava-se em um tubo com gradiente em densidade de sacarose (10 a $40 \% \mathrm{p} / \mathrm{v})$.

o tubo com o gradiente foi recuperado, utilizando-se pipeta Gilson da seguinte forma: 9 bandas de densidades decrescentes foram depositadas em $3 \times 167 \mu 2$ de tampão (NaCl IM, Tris $20 \mathrm{mM}$ e EDTA $5 \mathrm{mM}, \mathrm{pH} 8,0$ ) contendo $40 \%, 36,2 \%, 32,5 \%, 28,75 \%$, $25 \%, \quad 21,25 \%, \quad 17,5 \%, 13,75 \%$ e $10 \%$ de sacarose. 0 volume total do tubo continha 4,5ml de sacarose juntamente com $0,5 \mathrm{ml}$ do CNA cromossómico. 
Centrifugou-se a 28.000 r.p.m. a $20^{\circ} \mathrm{C}$ durante 16 a 18 horas. Frações de $100 \mu l$ foram coletadas e examinadas (uma em cada três fraçōes) em eletroforese. Para esta ültima foram utilizados $1,5 \mu \ell$ de cada fração aos quais adicionavam- se $20 \mu l$ de TE e 10Hl de SB.

4.25. Formação do ONA recombinante

Para a construção do DNA recombinante, em um tubo Eppendorf foram colocados: $50 \mu \ell$ do vetor pVA $749 \Delta$ digerido

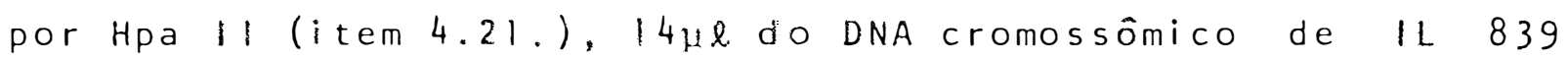
parcialmente digerido por Hpa 11 (item 4.23. e 4.24.) e $376 \mu \ell$ de àgua estéril. Aqueceu-se durante 5 min a $56^{\circ} \mathrm{C}$ e resfriou-se a $20^{\circ} \mathrm{C}$. Adicionaram-se $50 \mu \ell$ de tampão de ligação (item 4.5.25.) e $10 \mu \ell$ da enzima T4 DNA I igase. Incubou-se a $19^{\circ} \mathrm{C}$ durante 18 horas e efetuou-se uma eletroforese de controle contendo loul das misturas, antes e depois da ligação, juntamente com o DNA do fago $\lambda$ digerido por Hind 111 , para confirmar se a ligação havia ocorrido.

O restante do ONA recomblnante foi dialisado em TE, precipitado com etanol e ressuspendido em looul de TE.

4.26. Thansjómação de protoplastos (SIMON et alie, 1985)

$18 \mathrm{ml}$ de cultura de S. Eactis 111403 crescida em MI7 durante 1 a 1,5 horas a $30^{\circ} \mathrm{C}$, ou seja, no inicio de sua fa se de crescimento exponencial. foram centrifugados durante 10 min a 6.000 r.p.m. à temperatura ambiente. As células foram 
lavadas com ägua destilada e esterilizada e ressuspendidas 5,2me de SMM + M17 (item 4.5.21.), juntamente com 20mg/m de lisozima comercial AFILACT preparada anteriormente. As células se transformaram em protoplastos durante incubação a $37^{\circ} \mathrm{C}$ por 2 horas. A mistura foi centrifugada a 5.000 r.p.m. durante 10 min. Os protoplastos assim formados foram lavados em $5,2 \mathrm{ml}$ de SMM + M17 e recuperados em 650 hl da mesma solução. A ocorrência de protoplastização foi verificada em microscópio com contraste de fase.

Uma vez observada e confirmada a protoplastização efetuou-se o seguinte procedimento: aos $650 \mu l$ da solução contendo os protoplastos, adicionaram-se $100 \mu l$ do DNA transfor mante ou 5 ül de ägua (controle 1) ou somente 5 Hl do vetor pVA $749 \Delta$ (controle 2) e a mesma quantidade de SMM dupla concentração. Os tubos foram incubados durante 10 min à temperatura ambiente, apös os quais adicionaram-se $2 \mathrm{ml}$ de PEG 40\% (item 4.5.22.). Efe Euou-se nova incubação durante $20 \mathrm{~min}$ à temperatura ambiente, adicionando-se, a sequir, 6,5me de SMM + M17.

Os tubos sofreram centrifugação a 5.000 r.p.m. durante $10 \mathrm{~min}$, sendo os protoplastos recuperados em l, $3 \mathrm{~m}$ de $\mathrm{Ml} 7$ $\mathrm{Gli}+$ Sacarose $0,5 \mathrm{M}$. Incubaram-se-1hes durante 2 horas a $30^{\circ} \mathrm{C}$ para que o DNA introduzido se exprimisse antes de serem semeadas, segundo diluiçóes apropriadas em TP (item 4.5.13.), em MI7 $\mathrm{Gli}+$ Sacarose $0,5 \mathrm{M}$, adicionado ou não do agente seletivo, no caso, 5 Hg de eritromicina por mililitro. 
Todas as placas contendo as diferentes diluições e meios foram incubadas a $30^{\circ} \mathrm{C}$ durante 7 dias, para permitir uma regeneração completa dos protoplastos. Após este período, foram transferidas para MI7 Gli as colónias crescidas nas placas que continham MI7 Gli + Sacarose + agente seletivo e que tinham sido semeadas com diluições da mistura que continha o DNA transformante. 
5. RESULTADOS E DISCUSSÃO

5.1. Testes tecnolögicos ebetuados com estreptococos lácticos pertencentes a colecáo de culturas läcticas do ITAL

\subsubsection{Capacidade de coagulação do leite RSM a $23^{\circ} \mathrm{C}$ durante 18 horas}

Segundo LAWRENCE et alii (1976), um dos primeiros critérios de seleção de bactérias läcticas mesöfillas, utilizados internacionalmente, é a capacidade dessas bactérias coagularem o leite desnatado reconstituído dentro de 18 horas a $22-23^{\circ} \mathrm{C}$. HEAP e LAWRENCE (1981) consideram que não são interessantes, do ponto de vista tecnolögico, culturas que não coagulem o leite naquelas condições. 
Apesar da caracterização tecnológica não ter sido o objetivo principal do presente trabalho, foi realizado es te e mais alguns outros testes tecnológicos com culturas mesófi las pertencentes à coleção de culturas lácticas do ITAL, a fim de iniciar um processo de seleção.

os resultados obtidos, sumarizados na Tabela 1 , evidenciaram que, de 124 culturas ensaiadas, apenas 17 não cresceram a $23^{\circ} \mathrm{C}$, apōs 18 horas de incubação em leite RSM esteril i zado. Segundo CITTI et alie (1965), LAWRENCE et alie (1976), BOTAZZI (1979) e COGAN (1980), as culturas que não conseguem coa gular o leite nessas condições são consideradas lentas, sendo este, inclusive, um dos métodos para diferenciá-las também, quanto a este aspecto.

De acordo com as observações de cox (1977), as 107 culturas que se desenvolveram bem a $23^{\circ} \mathrm{C}$ säo, a princípio, consideradas boas para a utilização como fermento, visto que têm menores chances de apresentar perda de sua capacidade acidificante.

Algumas das culturas selecionadas por meio deste método, foram utilizadas nos testes tecnolögicos seguintes totalizando 124. Estas incluen algumas culturas que não cresceram a $23^{\circ} \mathrm{C}$ durante 18 horas, mas que posteriormente tiveram seu perfil de plasmidios determinado (item 5.2.). 
TABELA 1. Resultados da capacidade de coagulação do leite RSM após incubação a $23^{\circ} \mathrm{C}$ durante 18 horas.

\begin{tabular}{|c|c|c|c|c|c|}
\hline $\begin{array}{c}\text { Cultura } \\
\text { N: }\end{array}$ & Coagulação & $\begin{array}{c}\text { Cultura } \\
\text { No }\end{array}$ & Coagulação & $\begin{array}{c}\text { Cultura } \\
N ?\end{array}$ & Coagu lação \\
\hline 16 & + & 195 & + & 284 & + \\
\hline 96 & - & 196 & + & 285 & + \\
\hline 97 & + & 202 & - & 286 & + \\
\hline 100 & + & 203 & + & 287 & + \\
\hline 101 & + & 204 & + & 288 & + \\
\hline 104 & + & 205 & - & 289 & + \\
\hline 105 & - & 206 & - & 290 & + \\
\hline 141 & + & 207 & + & 291 & + \\
\hline 161 & + & 208 & + & 292 & + \\
\hline 162 & - & 209 & + & 293 & + \\
\hline 163 & + & 210 & + & 294 & + \\
\hline 164 & - & 211 & + & 295 & + \\
\hline 165 & + & 222 & + & 296 & + \\
\hline 166 & + & 224 & + & 297 & + \\
\hline 167 & + & 226 & t & 298 & + \\
\hline 168 & + & 227 & + & 299 & + \\
\hline 169 & + & 228 & + & 300 & + \\
\hline 170 & + & 229 & + & 301 & + \\
\hline 171 & + & 230 & + & 302 & + \\
\hline 172 & + & 231 & + & 303 & + \\
\hline 173 & + & 246 & + & 304 & + \\
\hline 174 & + & 247 & - & 305 & + \\
\hline 175 & + & 250 & + & 306 & + \\
\hline 176 & + & 252 & + & 307 & + \\
\hline 177 & + & 254 & + & 308 & + \\
\hline 178 & - & 255 & + & 309 & + \\
\hline 179 & + & 256 & + & 310 & + \\
\hline 180 & - & 257 & + & 311 & + \\
\hline 181 & + & 259 & + & 312 & + \\
\hline 182 & + & 261 & + & 313 & + \\
\hline 183 & + & 262 & + & 314 & + \\
\hline 184 & + & 263 & + & 315 & + \\
\hline 185 & + & 265 & + & 316 & + \\
\hline 186 & - & 268 & + & 317 & + \\
\hline 187 & - & 269 & + & 318 & + \\
\hline 188 & + & 272 & $\ldots$ & 319 & + \\
\hline 189 & - & 273 & + & 320 & + \\
\hline 191 & - & 279 & + & 321 & + \\
\hline 192 & + & 280 & + & 322 & + \\
\hline 193 & + & 281 & + & 323 & + \\
\hline \multirow[t]{2}{*}{194} & - & 282 & + & 324 & - \\
\hline & & 283 & + & & \\
\hline
\end{tabular}




\section{1.2. Teste de sensibilidade à temperatura}

A capacidade de produzir certa quantidade de àci do durante o processo de fabricação é um fator muito importante na seleção de culturas lácticas. Para este fim, foram elabo rados värios testes de atividade que relacionem, de forma geral, a nível de laboratório, a produção de ácido durante o pro cessamento, tendo em vista a dificuldade prática de se basear todas as linhagens isoladas por meio da fabricação de queijo (BABEL, 1955; SOZZI, 1973; STADHOUDERS e HASSING, 1972; GUDKOV e.t alii, 1980 e HEAP e LAWRENCE, 1981).

Segundo BABEL (1962) e SPECK (1982) deve-se considerar, nestes testes, o tipo de tratamento térmico sofrido pelo leite, jă que substāncias inibidoras e estimulantes podem ser destruidas ou formadas durante o aquecimento. Geralmente recomenda-se, para o teste de atividade, a temperatura de $30^{\circ} \mathrm{C}$ por estar pröxima da temperatura em que a produção de ácido ë normalmente maior (COX, ig77 e INTERNATIONAL DAIRY FERMENTATION, 1982). GARCIA (1984) considera que esse valor è adequado, quando as temperaturas de cozimento são inferiores a $35^{\circ} \mathrm{C}$, porém, em queijos onde a temperatura excede esse valor durante a fabricação, é desejävel utilizar no teste condições de tempe ratura de acordo com aquelas empregadas na prática, umavez que as bactérias lácticas diferem grandemente na sua resistência às temperaturas de cozimento (BABEL, 1962 e DUTTA et alie, 1972). 
No processamento de muitos queijos de massa cozi da e semi-cozida, como o tipo Prato, é importante que o fermen to produza as condições necessárias para que as reações químicas essenciais tenham seqüência, resultando na liberação de precursores do aroma, devido à quebra enzimica dos componentes do leite, ben como num baixo pH, que regula a velocidade das reaçöes e um reduzido Eh que mantém compostos como o meta notiol na sua forma reduzida (LEGG, 1973 e cox, 1977).

o desenvolvimento do fermento läctico ainda tem sido relacionado ao aparecimento de sabor amargo em queijos, devendo-se fazer, dessa forma, uma avaliação do teor de peptídeos amargos formados durante o crescimento em leite (KLIMOVSKII et alii, 1973 e BELOVA et alii, 1982). o sabor amargo resulta, basicamente, da ação de proteinases sobre proteínas especí. ficas, tanto oriundas do fermento como do coalho. MARCos et ali (1977) consideram importante a determinação da atividade proteolítica na seleçäo de fermentos para a indūstria.

HEAP ct alie (1978) consideram como não originárias de amargor, as cepas que não se multiplicam rapidamente a $37-38^{\circ} \mathrm{C}$, mas que apresentam bom crescimento a $35^{\circ} \mathrm{C}$ ou menos. - $e s s a$ forma, estinou-se a atividade acidificante dos estreptococos läcticos pertencentes à coleção do ITAL, jà ensaiados no item anterior. Utilizou-se a tëcnica descrita no item 4.7., incubando-os em diferentes temperaturas, as quais simulam as condições de fabricação dos queijos de massa semi-cozida. Esses resultados estão sumarizados na Tabela 11. 
TABELA \|. Efeito da cemperatura de incubação na capacidade acidificante.

\begin{tabular}{|c|c|c|c|c|c|}
\hline \multirow{2}{*}{$\begin{array}{c}\text { Cultura } \\
\text { No }\end{array}$} & \multicolumn{2}{|c|}{ pH após incubação } & \multirow{2}{*}{$\begin{array}{c}\text { Cultura } \\
\text { No }\end{array}$} & \multirow{2}{*}{$\begin{array}{l}\text { pH após } \\
5 \text { horas } \\
\text { a } 30^{\circ} \mathrm{C} \\
\end{array}$} & \multirow{2}{*}{$\begin{array}{l}\text { incubação } \\
90 \mathrm{~min} \text { a } 30^{\circ} \mathrm{C} \\
\mathrm{e} 4 \mathrm{~h} \text { a } 38^{\circ} \mathrm{C}\end{array}$} \\
\hline & $\begin{array}{l}5 \text { horas } \\
\text { a } 30^{\circ} \mathrm{C}\end{array}$ & $\begin{array}{l}90 \mathrm{~min} \text { a } 30^{\circ} \mathrm{C} \\
\mathrm{e} 4 \mathrm{~h} \text { a } 38^{\circ} \mathrm{C}\end{array}$ & & & \\
\hline 16 & 4,20 & 4,78 & 183 & 5,50 & 4,98 \\
\hline 96 & 6,40 & 6,37 & 184 & 5,70 & 4,95 \\
\hline 97 & 4,95 & 4,46 & 185 & 6,00 & 4,87 \\
\hline 100 & 5,35 & 5,42 & 188 & 5,00 & 4,61 \\
\hline 101 & 5,70 & 5,40 & 192 & 5,80 & 4,79 \\
\hline 104 & 5,40 & 5,49 & 193 & 5,10 & 4,83 \\
\hline 105 & 5,50 & 5,95 & 195 & 5,40 & 4,84 \\
\hline 141 & 5,00 & 5,22 & 196 & 5,15 & 4,84 \\
\hline 161 & 6,50 & 6,28 & 203 & 5,10 & 4,83 \\
\hline 162 & 6,35 & 5,85 & 204 & 5,00 & 4,84 \\
\hline 163 & 5,50 & 4,74 & 206 & 6,50 & 6,30 \\
\hline 165 & 6,50 & 4,98 & 207 & 4,30 & 4,84 \\
\hline 166 & 5,00 & 5,03 & 208 & 5,20 & 4,82 \\
\hline 167 & 5,00 & 4,92 & 209 & 5,10 & 4,82 \\
\hline 168 & 4,75 & 4,66 & 210 & 6,60 & 4,61 \\
\hline 169 & 4,95 & 4,96 & 211 & 5,20 & 4,75 \\
\hline 170 & 5,00 & 4,95 & 222 & 6,50 & 4,88 \\
\hline 171 & 5,10 & 4,95 & 224 & 6,45 & 5,00 \\
\hline 172 & 4,70 & 4,42 & 225 & 4,95 & 4,98 \\
\hline 173 & 6,4 & 4,75 & 226 & 5,25 & 4,90 \\
\hline 174 & 5,05 & 4,61 & 227 & 5,10 & 4,78 \\
\hline 175 & 6,40 & 4,60 & 228 & 5,45 & 4,88 \\
\hline 176 & 5,50 & 4,87 & 229 & 6,50 & 4,76 \\
\hline 177 & 5,40 & 4,83 & 230 & 5,10 & 4,99 \\
\hline 178 & 6,40 & 6,4 & 232 & 6,60 & 4,85 \\
\hline 179 & 5,00 & 4,70 & 246 & 5,40 & 4,82 \\
\hline 181 & 5,20 & 5,05 & 250 & 6,00 & 4,52 \\
\hline 182 & 5,30 & 4,44 & 252 & 5,15 & 4,50 \\
\hline
\end{tabular}


TABela $\|$. Continuação.

\begin{tabular}{|c|c|c|c|c|c|}
\hline \multirow{2}{*}{$\begin{array}{l}\text { Cult tura } \\
\text { No }\end{array}$} & \multicolumn{2}{|c|}{ pH apōs incubação } & \multirow{2}{*}{$\begin{array}{l}\text { Cultura } \\
\text { No }\end{array}$} & \multicolumn{2}{|c|}{ pH após incubação } \\
\hline & $\begin{array}{l}5 \text { horas } \\
\text { a } 30^{\circ} \mathrm{C}\end{array}$ & $\begin{array}{l}90 \min \text { a } 30^{\circ} \mathrm{C} \\
\text { e } 4 \mathrm{~h} \text { a } 38^{\circ} \mathrm{C}\end{array}$ & & $\begin{array}{l}5 \text { horas } \\
\text { a } 30^{\circ} \mathrm{C}\end{array}$ & $\begin{array}{l}90 \min \text { a } 30^{\circ} \mathrm{C} \\
\mathrm{e} 4 \mathrm{~h} \text { a } 38^{\circ} \mathrm{C}\end{array}$ \\
\hline 254 & 4,90 & 4,80 & 296 & 4,80 & 4,86 \\
\hline 255 & 5,90 & 4,97 & 297 & 5,00 & 4,98 \\
\hline 256 & 5,70 & 4,98 & 298 & 5,00 & 4,90 \\
\hline 257 & 5,00 & 4,90 & 299 & 5,15 & 4,97 \\
\hline 259 & 6,50 & 4,67 & 300 & 5,00 & 4,87 \\
\hline 261 & 4,75 & 4,56 & 301 & 5,20 & 5,21 \\
\hline 262 & 4,00 & 4,55 & 302 & 4,95 & 5,15 \\
\hline 263 & 5,50 & 4,88 & 303 & 6,50 & 5,36 \\
\hline 265 & 5,20 & 4,59 & 304 & 6,55 & 5,17 \\
\hline 268 & 5,30 & 5,35 & 305 & 5,00 & 5,31 \\
\hline 269 & 6,35 & 5,41 & 306 & 4,90 & 5,28 \\
\hline 273 & 6,20 & 4,52 & 307 & 4,85 & 5,15 \\
\hline 279 & 5,35 & 4,55 & 308 & 6,40 & 5,18 \\
\hline 280 & 5,20 & 4,71 & 309 & 6,40 & 5,36 \\
\hline 281 & 4,90 & 4,88 & 310 & 6,30 & 5,28 \\
\hline 282 & 4,90 & 4,95 & 311 & 5,40 & 5,74 \\
\hline 283 & 5,00 & 5,06 & 312 & 6,35 & 5,41 \\
\hline 284 & 4,85 & 4,92 & 313 & 5,25 & 5,15 \\
\hline 285 & 4,90 & 4,92 & 314 & 5,25 & 5,12 \\
\hline 286 & 5,00 & 4,96 & 315 & 5,80 & 5,01 \\
\hline 287 & 4,90 & 5,03 & 316 & 5,35 & 5,19 \\
\hline 288 & 5,00 & 5,05 & 317 & 4,90 & 5,27 \\
\hline 289 & 4,95 & 4,92 & 318 & 6,50 & 4,98 \\
\hline 290 & 4,90 & 4,93 & 319 & 5,25 & 5,16 \\
\hline 291 & 5,00 & 4,94 & 320 & 6,35 & 5,39 \\
\hline 292 & 5,00 & 4,90 & 321 & 4,80 & 5,34 \\
\hline 293 & 5,00 & 4,91 & 322 & 4,80 & 5,22 \\
\hline 294 & 5,00 & 4,87 & 323 & 6,50 & 5,23 \\
\hline 295 & 5,00 & 4,91 & 324 & 6,60 & 5,24 \\
\hline
\end{tabular}


o valor do pH das linhagens 161 e 301 foi tomado como padrão para caracterização de culturas tipo lentas e rápí das, respectivamente (HEAP e LAWRENCE; 1976). Isso significa que a cultura 161 acidifica o leite, porém, a cultura 301 o faz mais rapidamente quando a temperatura é aumentada para $38^{\circ} \mathrm{C}$.

Verifica-se pela Tabela 11 , que a grande maioria das culturas são do tipo rāpidas, jā que os valores de pH situaram-se abaixo de 6,50 e 6,28, pís da cultura 161 após incubação a $30^{\circ} \mathrm{C}$ durante 5 horas e $90 \mathrm{~min}$ a $30^{\circ} \mathrm{C}+4$ horas a $38^{\circ} \mathrm{C}$. As linhagens lentas apresentam essa característica por não pos suírem, ou terem perdido, o sistema de proteinase, sendo, então, denominadas de Prt-, enquanto as que mantēm aquele sistema são Prtt (McKAY, 1983).

Os resultados obtidos foram semelhantes aos veri ficados por GARCIA (1984) observando-se, para a maioria das cul. turas, uma melhor acidificação após incubação a $30^{\circ} \mathrm{C}$ durante $90 \mathrm{~min}$ e, em seguida, 4 horas a $38^{\circ} \mathrm{C}$.

Atualmente, as culturas Prt ${ }^{-}$tèm recebido atenção especial no campo lacticinista internacional, chegando me $\underline{s}$ mo a ser indicadas como culturas preferenciais na fabricação de queijos, devico a três características vantajosas que apresentam: redução do potencial de amargor, maior resistência a bacteriöfagos e maior rendimento do produto (LAWRENCE et alii, 1976; COGAN, 1980; MCKAY, 1983 e HUGGINS, 1984). ANTUNES (1985) ciscute que o potencial para a utilização de misturas apropria das de Prt e Prt ${ }^{+}$pode ser mais desejävel e oferecer algumas 
vantagens adicionais, como melhor controle do desenvolvimento de sabor e aroma e aumento de rendimento. Dessa forma, seria necessário ensaiar composições de fermentos contendo culturas rāpidas e lentas, apresentadas na Tabela 11 , acompanhando a maturação do queijo processado para se poder fazer uma seleção dessas culturas.

\subsubsection{Teste de liberação espontânea de bacterió fagos}

HULL e BROOKE (1982) mostram um aumento na replicação de fagos do leite cru nos testes de atividade conduzi dos a $35^{\circ} \mathrm{C}$, tendo ocorrido pouco desenvolvimento a $30^{\circ} \mathrm{C}$. Indubitavelmente, temperaturas elevadas encontradas durante o processamento de queijo podem incrementar a replicação de fagos em algumas linhagens que previnem ou restringem o desenvolvimento lítico em temperaturas mais baixas. Assim, linhagens que não favorecem a replicação de fagos heterólogos em temperaturas elevadas podem, de fato, ser mais desejāveis de incorporação em fermentos lácticos.

O teste de atividade proposto por HEAP e LAWRENCE (1976, 1981) prediz a longevidade de uma determinada linhagem em condições de processamento. Assim, as 124 linhagens em estudo foram sujeitas a repetidos ciclos de crescimento em pre sença de amostras de "soros" (meio filtrado) provenientes de seu próprio crescimento no dia anterior. Utilizaram-se, ainda, condições de tempo e temperatura que imitam aquelas encontradas durante os processamentos (item 4.9.). 
Pelos resultados obtidos, pode-se concluir que as culturas 166 e 280 não são adequadas para serem usadas em fermentos simples ou mistos, pelo fato de terem liberado bacte riófagos, espontaneamente, após $07 \%$ e 5 : dia de atividade res pectivamente. Isto é evidenciado pelo aumento do pH, situando- se próximo ou acima do pH do controle, não mais ocorrendo ac i. dificação. As Figuras 1 e 2 sumarizam esses resultados. As demais culturas ensaiadas, entretanto, poderiam ser utilizadas para aquele fim, no que diz respeito à liberação espontânea de fagos.

Este teste deve ser complementado com o de indução de profagos atravēs de agentes mutagênicos, para que se pos sa afirmar que as outras culturas não ocasionariam probiemas de bacteriófagos às demais linhagens componentes de um fermento làctico.

5.2. Perfil de plasmidios de estreptococos läcticos pertencentes à coleção do ITAL

Os plasmidios de 58 culturas de estreptococos lácti cos. provenientes da coleção do ITAL foram extraídos segundo me todologia descrita no item 4.14 .1 .

os resultados obtidos confirmam o valor do método utilizado para a identificação de plasmídios de linhagens de estreptococos lácticos. Ademais, permite estabelecer comparações entre os diferentes perfis, como já havia sido descrito por CHOPIN e LANGELLA (1982), para plasmídios de 60 linhagens 


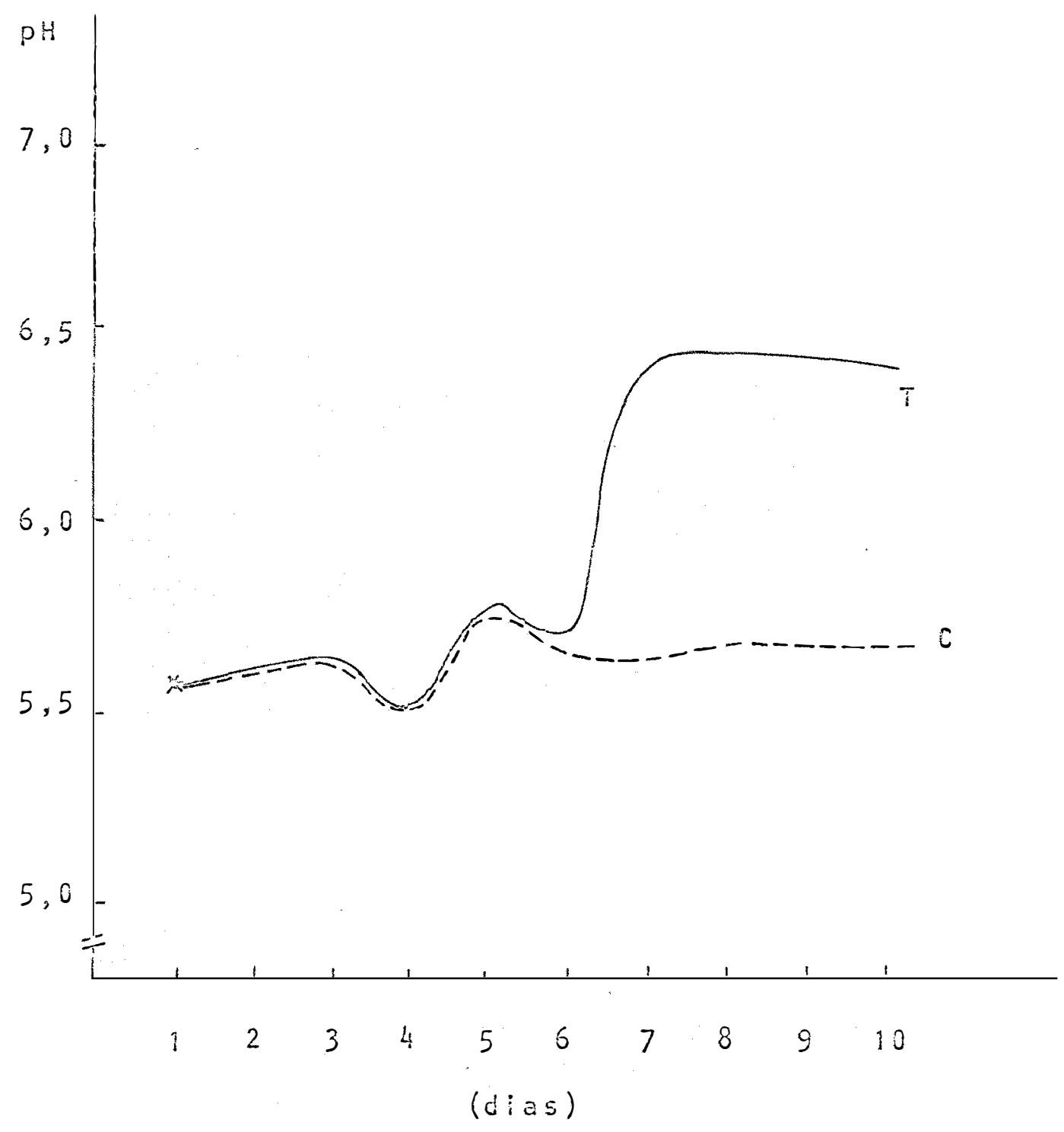

Flgura 1. Curvas de atividade da cultura ló com liberação espontânea de fagos, sendo $C=$ tubos-controle e $T=t \underline{u}$ bos-teste. 


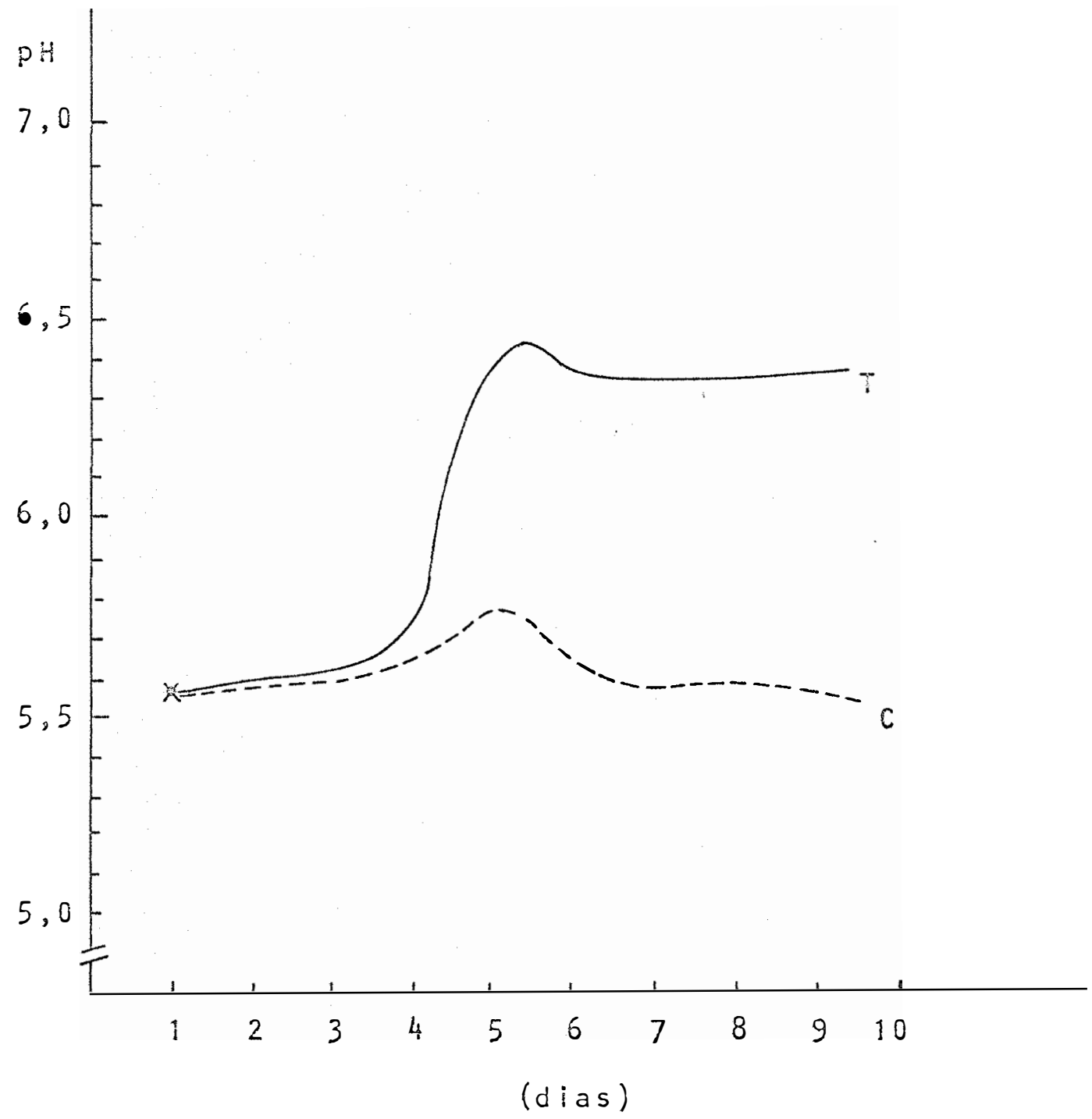

FIGURA 2. Curvas de atividade da cultura 280 com liberação espontânea de fagos, sendo $C=$ tubos-controle e $T=t \underline{u}$ bos-teste. 
extraídos pelo mëtodo de GASSON e DAVIES (1980 c).

Pelos resultados expostos nas Figuras 3 e 4,21 culturas apresentaram perfis de plasmídios distintos, sendo que seu nümero, por cultura, variou de um a onze (linhagem 308 ). Estes nümeros são inferiores aos descritos por DAVIES et alii, (1981), os quais encontraram até 14 plasmídios em algumas culturas. CHOPIN e LANGELLA (1982) discutem que, talvez, nem to das essas 14 bandas encontradas representem, realmente, plasmí àios diferentes pois, segundo a técnica de extração utilizada, um mesmo plasmídio pode ter seu ácido nuclēico presente no extrato sob diferentes formas, ou seja, super-espiraladas, relaxadas e lineares, as quais resultam em bandas distintas após eletroforese. No presente caso, desde que foi utilizada uma tẹc nica de extração alcalina, a qual resulta, raramente, em formas relaxadas, pode-se pensar que todas as 11 bandas observadas, no caso da cultura 308 , correspondem inequivocamente a plasmídios, ou seja, a formas super-espiraladas.

Observam, igualmente, analogias no conteüdo de plasmídios de 43 culturas, cujos tipos estão representados na Figura 5. Duas culturas $(179$ e 320$)$ apresentaramo perfil de plasmídios do tipo A; cinco delas $(280,313,316,317$ e 319), o perfil do tipo B; vinte e sete $(141,16,318,321,323,324$ e 281 a 301$)$, o perfil do tipo C; trés culturas (303, 305 e 306$)$ o perfil do tipo D; trés culturas $(175,178$ e 206), o perfil do tipo E e outras três $(167,168$ e 169), o perfil plasmidial do tipo $F$. 


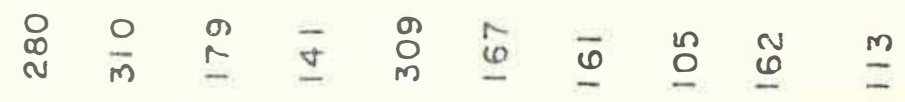

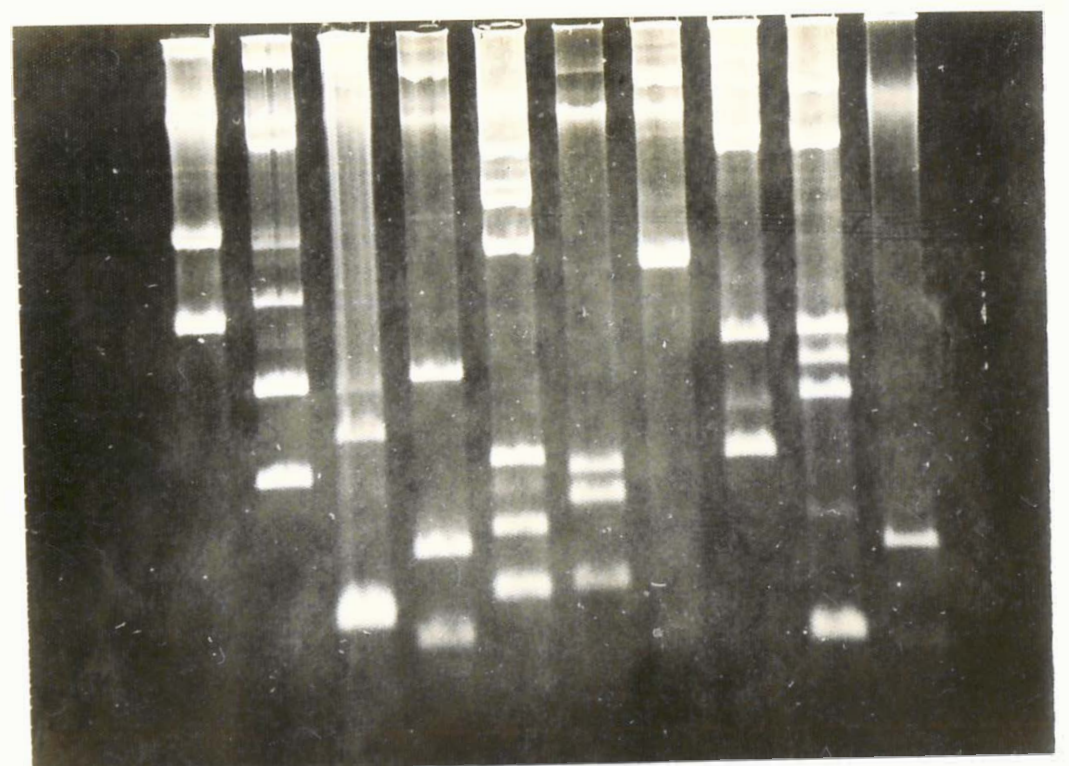

FIGURA 3. Diferentes perfis de plasmidios de linhagens. de estreptococos läcticos da coleçào do ITAL. 


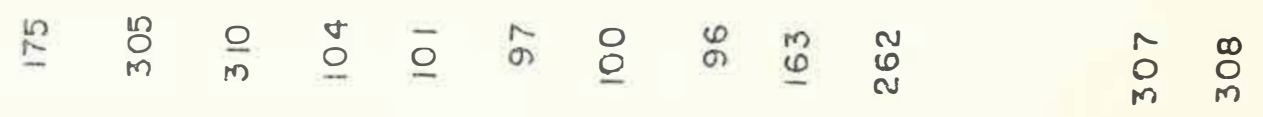

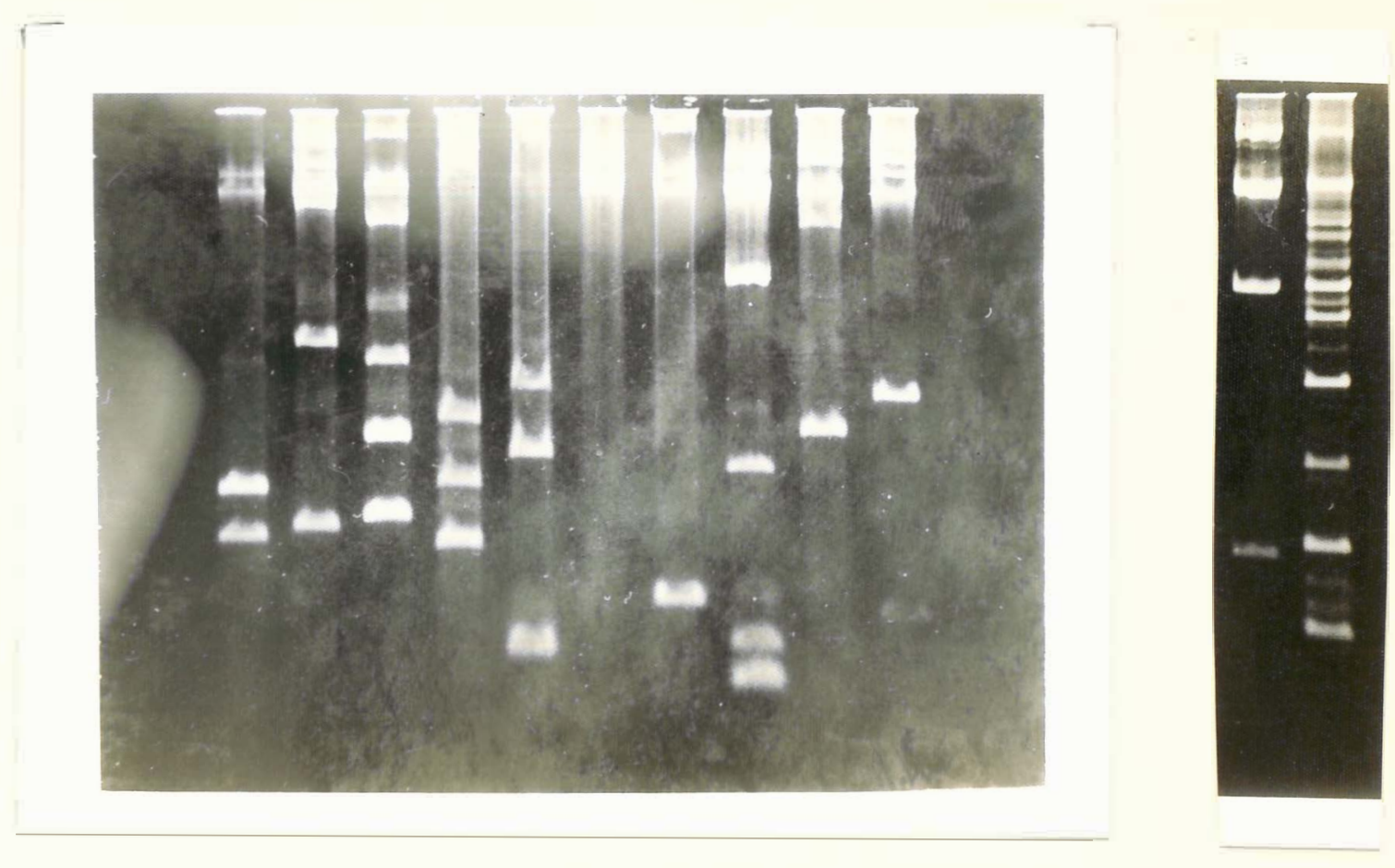

FIGURA 4. Diferentes perfis de plasmídios de linhagens de estreptacocos lácticos da coleção do ITAL. 
A freqüência de plasmídios anālogos foi aproxima damente de $1 / 3$, ou seja, a mesma encontrada por PECHMANN e TEU BER (1980) com 51 culturas. Já DAVIES et alii (1981) encontraram apenas 4 linhagens com perfis anälogos, dentre um grande nümero de culturas, sendo que as demais apresentavam perfis de plasmidios variados e específicos. Entretanto, esses autores verificaram que as 4 linhagens idènticas derivavam de uma mesma cultura de origem, evidenciando, portanto, qué a utilização de perfis de plasmidios era um excelente método para reconhecer diferentes iinhagens. Yu et alii (i983) concluíram, igua mente, que perfis de plasmídios tão diferentes e especificos para cada organismo poderiam ser utilizados na identificação das diversás culsuras lä́cticas.

Este fato tambēm foi comprovado no presente trabalho, jä que as culturas possuindo o perfil tipo E (Figura 5) são oriundas de uma mesma cultura, assim como aquelas de nümeros 281 a 300 , perfil tipo C, também são provenientes de uma ünica cultura de origem.

Dessa forma, o conhecimento do perfil de plasmidios das culturas lácticas pertencentes à coleção do ITAL é de extrema importáncia, pois muitas delas foram isoladas de soros provenientes de processamentos de diferentes indústrias e, con seqüentemente, de fermentos comerciais que podem ser idénticos.

De acordio com CHOP!N e LANGELLA (1982), a analogia de perfis de plasmídios não é surpreendente, podendo-se su por que as pequenas diferenças observadas nos perfis de algumas 

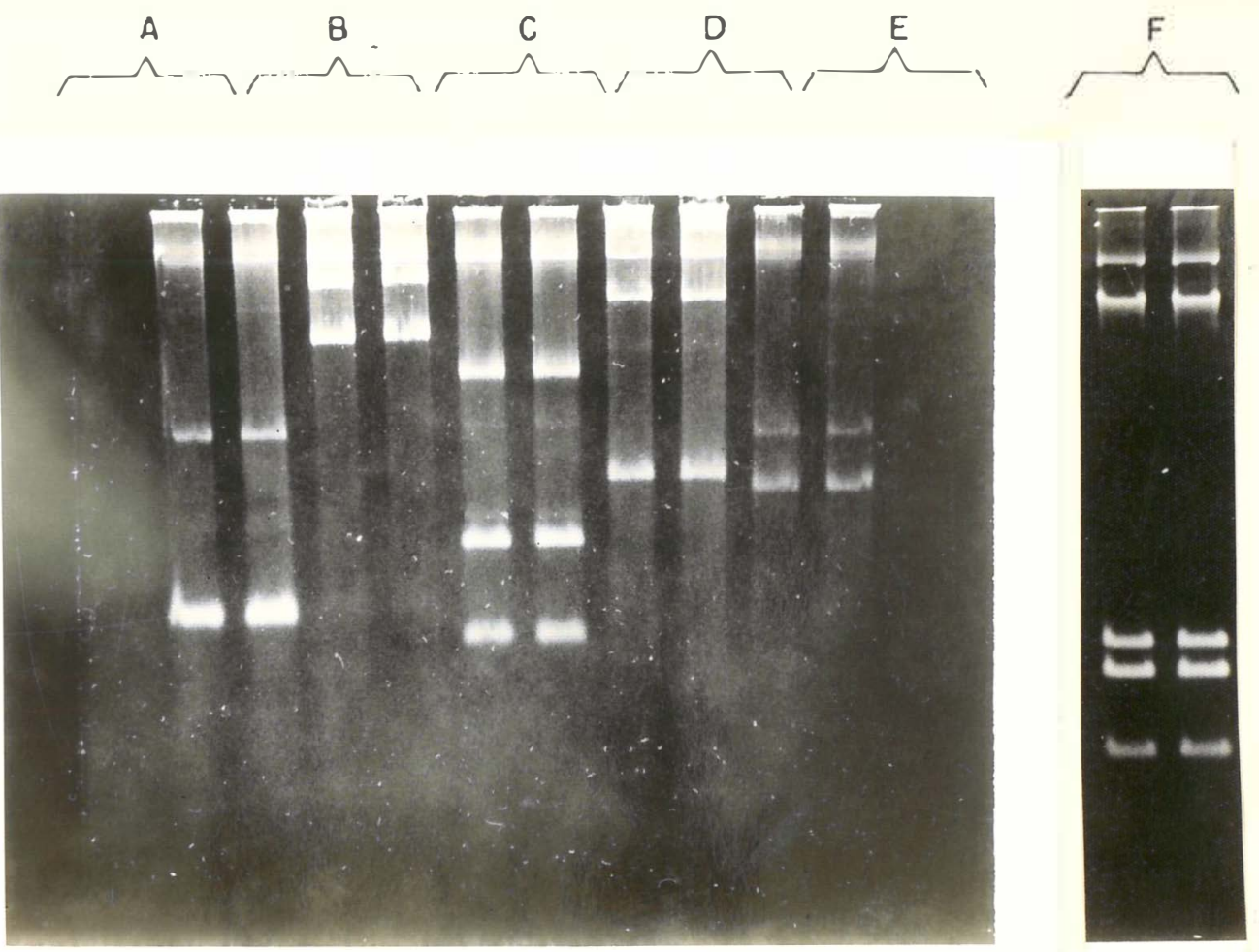

FIGURA 5. Perfis de plasmidios identicos de linhagens de estreptococos làcticos do colçào do ITAL. 
I inhagens que estudaram, resultem de variações nas pressões de seleção exercidas sobre elas, durante sua passagem nas diversas coleções.

Para complementar a informação sobre linhagens pos suindo perfis anälogos, hä necessidade de se testar a sua sensibilidade a bacteriófagos virulentos, estudo este que foi rea lizado e cuja discussão encontra-se no pröximo item deste trabaitho.

5.3. Tipagem e nivel de sensibilidade de estreptococos läcticos da coleção do ITAL a fagos virulentos pertencentes à coleção do INRA

Um dos métodos utilizados no. controle de bacteriōfagos na indüstria é a utilização de rotação de culturas que não sejam fago-relacionadas (LAWRENCE e PEARCE, 1972 e KEOGH, 1972). Para tanto, há necessidade de se conhecer a sensi bilidade das bactérias aos fagos, ou seja, realizar a sua tipa gem. A aplicação do mētodo de tipagem é grandemente facilitada, se forem estabelecidos grupos de linhagens que não apresentem - mesmo padrão de sensibilidade aos fagos utilizados para a ti pagem, assim como a escolha de linhagens e de fagos de cada grupo que permitam uma räpida classificação, tanto de um novo fago, como de uma nova linhagem isolada (CHOPIN et alie, 1976). Neste sentido, vārios tipos de agrupamentos de fagos possuindo reações líticas similares foram criados (NiCHOLS e HOYLE, 1949; HENNING et alii, 1968; LEMBKE et alii, 1972 e ENGEL et alii, 1975) e complementados com estudos sorológicos dos fagos 
(NICHOLS e HOYLE, 1949; WILKOWSKE et alii, 1954 e ENGEL et alii, 1975).

CHOPlN et alii (1976) montaram um sistema de agrü pamento de fagos, segundo sua ação lítica, assim como um outro de estreptococos läcticos baseado na sua sensibilidade aos bac teriöfagos virulentos. As 2! linhagens de estreptococos läcticos da coleção do ITAL, que apresentaram perfis distintos de plasmidios foram ensaiadas contra 10 bacteriófagos representativos de 6 grupos liticos definidos por aqueles autores e pertencentes à coleção do INRA. A Tabela lll resume os resultados obtidos.

Observou-se que $47,6 \%$ das I inhagens testadas foram sensíveis a um ou vários fagos virulentos, pertencentes aos grupos liticos $g l(4,7 \%), g 2(19 \%)$ e $g 3(23,8 \%)$. Não se ob tiveram resultados positivos de sensibilidade aos demais fagos ensaiados pertencentes aos grupos 94 (fago 25 ), g5 (fago 119) e g6 (f́ago 42). Por outro lado, as demais linhagens ensaiadas $(52,4 \%)$ mostraram-se resistentes a fagos de todos os 6 grupos liticos; essa percentagem foi maior que aquela de $10 \%$ observada por NICHOLS e HOYLE (1949), e a de $31 \%$ obtida por HENNING et alii (1968). Estes ültimos autores consideram que a ausência de fagos ativos contra $31 \%$ das linhagens que testaram era devida ao fato das mesmas terem vindo de outras regiões e, por tanto, não terem sido usadas nas fäbricas onde os fagos tinham sido isolados. Isto pode adequar-se ao caso presente, já que a maioria das culturas era proveniente do Brasil e todos os 
TABELA \|ll. Sensibilidade de estreptococos lácticos brasileiros aos fagos virulentos da coleção do INRA.

\begin{tabular}{|c|c|c|c|c|c|c|}
\hline \multirow{2}{*}{$\begin{array}{l}\text { Cuitura } \\
\text { No }\end{array}$} & \multicolumn{6}{|c|}{ N: fago } \\
\hline & $\begin{array}{c}8 \\
\lg T)^{*}\end{array}$ & $\begin{array}{c}6 \\
\lg 2) *\end{array}$ & $\begin{array}{c}52 \\
\lg 3) \times\end{array}$ & $\begin{array}{c}66 \\
\lg 3)\end{array}$ & $\begin{array}{c}67 \\
\lg 31\end{array}$ & $\begin{array}{l}188 \\
\lg 31\end{array}$ \\
\hline 168 & $\div$ & & & & & \\
\hline 307 & & + & . & & & \\
\hline 309 & & + & & & & \\
\hline 310 & & & & + & + & + \\
\hline 105 & & & & & & + \\
\hline 162 & & & & $\div$ & + & + \\
\hline 179 & & & $\div$ & & & \\
\hline 163 & & & & & + & + \\
\hline 16 & & $\div$ & & & & \\
\hline 262 & & + & & & & $\cdot$ \\
\hline
\end{tabular}

${ }^{*} g^{1}, g^{2}, g^{3}=$ Grupos liticos. 
fagos isolados em indüstrias de laticinios da França. Entretan to, CHOPIN et alii (1976) consideram que as linhagens resistentes obtidas poderiam ser sensíveis a um pequeno nümero de fagos raros ainda não isolados, lisogênicas para a maioria deles ou mutantes resistentes a fagos.

Os result ados obtidos com as culturas läcticas brasileiras confirmam aqueles de CHOPIN et alii (1976), quanto ao grupo lítico g3, tendo-se verificado, também, que a maioria das linhagens foi sensivel a fagos deste grupo, os quais agiram, na maioria dos casos, sobre duas ou mais linhagens de estreptococos lácticos.

As 10 culturas lácticas que mostraram-se sensíveis aos fagos virulentos, não a presentaram, porém, o mesmo ní vel de sensibilidade. Assim, segundo a cultura indicadora utilizada, a linhagem a ser classificada ou a cultura normal de propagação do fago. o nümero de fagos obtidos não foi o mesmo. Estes resultados estão representados pelos diferentes valores de capacidade de multiplicação dos fagos (eop) na Tabela IV.

Obtiveram-se, portanto, dois grupos de resultados: (1) culturas apresentando igual sensibilidade a um determinado fago quanto à sua cultura de propagação (eop = 1), por exemplo, as linhagens 168,179 e 163 em relação às linhagens de propagação IL lo (fago 3$),$ IL 598 (fago 52), IL 562 (fago 67) e IL 823 (fago 138) e 2 culturas apresentando sensibilidade me nor que as linhagens de propagação dos respectivos fagos, por exemplo, as linhagens $307,309,16,262,310,105$ e 162 em 
TABELA IV. Nivel de sensibilidade dos estreptococos läcticos brasileiros aos fagos viruientos da coleção do INRA.

\begin{tabular}{|c|c|c|c|c|c|c|}
\hline \multirow{2}{*}{$\begin{array}{c}\text { Cultura } \\
\text { No }\end{array}$} & \multicolumn{2}{|c|}{ Eficiência } & \multicolumn{4}{|c|}{ multiplicação dos fagos $(*)$} \\
\hline & 8 & 6 & 52 & 65 & 67 & 188 \\
\hline 168 & 1 & & & & & \\
\hline 307 & & $3,0 \times 10^{-6}$ & & & & \\
\hline 309 & & $1,3 \times 10^{-7}$ & & & & \\
\hline 310 & & & & $5,7 \times 10^{-4}$ & $7,3 \times 10^{-6}$ & $3,2 \times 10^{-4}$ \\
\hline 105 & & & & & & $1,1 \times 10^{-5}$ \\
\hline 162 & & & & $2,7 \times 10^{-2}$ & $3,0 \times 10^{-5}$ & $1,2 \times 10^{-3}$ \\
\hline 179 & & & 1 & & & \\
\hline 163 & & & & & $\tilde{i}$ & 1 \\
\hline 16 & & $1,4 \times 10^{-5}$ & & & & \\
\hline 262 & & $1,5 \times 10^{-5}$ & & & & \\
\hline
\end{tabular}

n? de fagos multiplicados sobre a cul*Eficiência de multiplicação $=\frac{\text { tura brasileira a ser classificada }}{\text { n? de fagos multiplicados sobre a cul- }}$ tura de propagação 
relação às linhagens de propagação $I L \quad 10$ (fago 8), IL 6 (fago 6), IL 1403 (fago 66), IL 562 (fago 67) e IL 823 (fago 188), respectivamente. Para este último grupo, tentou-se identificar - mecanismo de resistência presente naquelas culturas.

De posse dos resultados de nivel de sensibilidade aos fagos, procurou-se verificar se culturas que apresentavam pergis de plasmídios análogos possuíam igualmente, a mesma sensibilidade aos fagos líticos. Os dados obtidos foram positivos, determinando-se, dessa forma, que a eficiência de mul tiplicação do fago 8 sobre as culturas 166,167 e 169 era iden tica à da cultura 168, assim como a cultura 320 foi idéntica à obtida sobre a cultura 179. Esses resultados confirmam aqueles obtidos por CHOPIN e LANGELLA (1982) quanto à semelhança de perfis de plasmídios e espectro de sensibilidade identico a fa gos virulentos. Confirmou-se, também, que o sistema proposto por CHOPIN et alii (1976) pode ser aplicado para estreptococos lácticos provenientes de outras regioes, tendo-se podido classificar as linhagens sensiveis da seguinte forma: grupo Gl: II nhagem 168; grupo 62: Iinhagens $307,309,16$ e 262 e grupo G3: linhagens $310,105,162,179$ e 163.

5.4. Determinação de mecanismos de resistência a bacterióbá gos em estreptococos éacticos da coleção do ITAL

Verificou-se que as linhagens $310,162,105,307,16$, 262 e 309 , apresentaram um mecanismo de resistência a determinados 
fagos virulentos ensaiados (Tabela $(V)$. Estabeleceu-se posteriormente a existência de um mecanismo de restrição e modificação na linhagem 310 em relação aos fagos 66,67 e 188 de 4 $\log$ e na linhagem 162 em relação ao fago 66 de 2 log. Estes re sultados estão sumarizados nas Tabelas V e VI.

Após propagação do fago 66 sobre a linhagem IL 1403, obteve-se um título de somente 1 fago sobre $10^{4}$ sobre a linhagem 3i0. Desde que este fago foi propagado sobre 310 , ele foi modificado, podendo, então, multiplicar-se bem sobre esta I inhagem. Quando se propagou novamente sobre 141403 , ele perdeu a modificação adquirida sobre a linhagem 310 , a qual passou a restringi-lo como anteriormente.

Desta forma, estabeleceu-se que a resistência da I inhagem 310 aos fagos 188 e 67 era devida a este mecanismo de $R / M$ (resultados não apresentados).

Observou-se, entretanto, que as placas de lise formadas pelo fago 188 sobre as culturas 162 e 105 correspondiam a fagos mutantes. Assim, o fago 188 modificado quando de sua propagação na linhagem 105 conserva esta modifícação mesmo após sua mulitiplicação em 14 823. Não se trata, portanto, de uma modificação controlada pelo hospedeiro, mas de uma mutação (LURIA, 1953). Um exemplo destes resultados está representado na Tabela VII. 
TABELA V. Evidència de um mecanismo de restrição/modificação presente na linhagem 310, ativa contra o fago 66 .

\begin{tabular}{|c|c|c|c|}
\hline \multirow{2}{*}{$\begin{array}{l}\text { Linhagem } \\
\text { hospedeira }\end{array}$} & \multicolumn{3}{|c|}{ Eficiência de multiplicação doal } \\
\hline & $\begin{array}{l}\text { Fago } 66 \\
(1 \mathrm{~L} \quad 1403) \text { b/ }\end{array}$ & $\begin{array}{l}\text { Fago } 66 \\
(1 \mathrm{~L} 1403-310) \mathrm{C} /\end{array}$ & $\begin{array}{c}\text { Fago } 66(1 \mathrm{~L} \quad 1403-310 \\
\text { IL } 1403) \text { d }\end{array}$ \\
\hline $1 \mathrm{~L} \quad 1403$ & 1 & 1 & 1 \\
\hline 310 & $5,7 \times 10^{-4}$ & 1 & $3,2 \times 10^{-4}$ \\
\hline
\end{tabular}

a/ Eficiēncia de $=$ ne de fagos multiplicados sobre a cultura estudada multiplicação ne de fagos multiplicados sobre a cultura de propagação

b/ O fago 66 foi propagado sobre a linhagem $1 \mathrm{~L} 1403$.

c/ O fago 66 foi propagado sucessivamente sobre as I inhagens IL $1403 \div 310$.

d' O fago 66 foi propagado sucessivamente sobre as I inhagens IL 1403 e 310 e: L 1403. 
TABELA VI. Evidēncia de um mecanismo de restrição/modificação presente na linhagem 162, ativa contra o fago 66.

\begin{tabular}{|c|c|c|c|}
\hline \multirow{2}{*}{$\begin{array}{l}\text { Linhagem } \\
\text { hospedeira }\end{array}$} & \multicolumn{3}{|c|}{ Eficiência de multiplicação doal } \\
\hline & $\begin{array}{l}\text { Fago } 66 \\
(\text { (L 1403) b/ }\end{array}$ & $\begin{array}{l}\text { Faggo } 66 \\
(\text { IL } 1403-162) \text { c/ }\end{array}$ & $\begin{array}{c}\text { Fago } 66(1 \mathrm{~L} 1403-162 \\
\text { IL } 1403) \stackrel{d}{ }=\end{array}$ \\
\hline IL 1403 & 1 & 1 & 1 \\
\hline 162 & $2,9 \times 10^{-2}$ & 1 & $2,7 \times 10^{-2}$ \\
\hline
\end{tabular}

a/ Eficiência de $=$ n? de fagos multiplicados sobre a cultura estudada multiplicação no de fagos multiplicados sobre a cultura de propagação

- O fago 66 foi propagado sobre a linhagem IL 1403.

c/ O fago 66 foi propagado sucessivamente sobre as linhagens IL 1403 e 162 .

d/ O fago 66 foi propagado sucessivamente sobre as linhagens IL 1403 e 162 e IL 1403. 
TABELA VII. Evidência de um mecanismo de resistência apresentado pela linhagem 105, devido a mutaçöes sofridas pelo fago 188 .

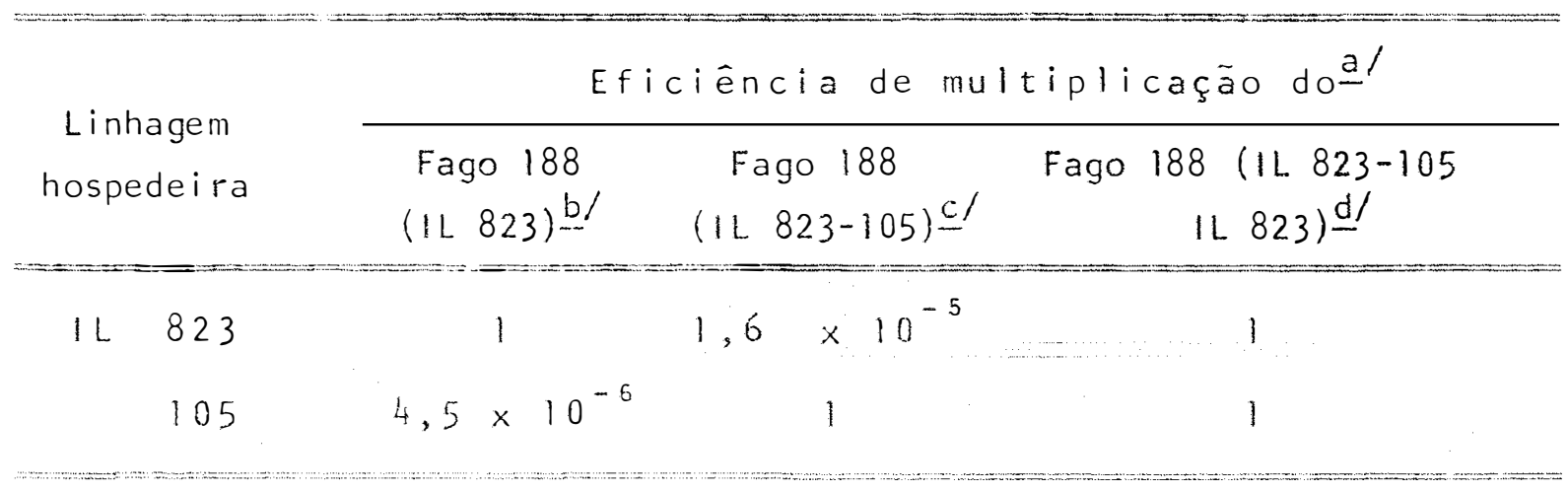

a/ Eficiência de $=\frac{\text { n? de fagos multiplicados sobre a cultura estudada }}{\text { multiplicaça }}$ gação

b/ O fago 188 foi propagado sobre a linhagem IL 823 .

c/ O fago 188 foi propagado sucessivamente sobre as linhagens IL 823 e 105.

d/ 0 fago 188 foi propagado sucessivamente sobre as linhagens IL 823 e 105 e IL 823 . 
o fago 6 causa provavelmente uma i isogenização nas culturas 307, 309, 16 e 262, as quais também apresentaram resisténcia ao mesmo, assim como o fago 67 sobre a linhagem 162 (Tabela IV). Isto foi evidenciado pela impossibilidade de multiplicação deste fago naquelas culturas, além do aspecto morfológico das placas de lise que apresentaram, ou seja, placas muito pequenas e turvas, de difícil visualização e contagem. Entretanto, não houve tempo häbil para que se pudesse com provar devidamente este fenómeno.

5.5. Verificaça de lisogenia cm estreptococos da colesao do lTAl por meio de induçäo com luz ultravioleta $(11, v$,

os estreptococos làcticos podem ser uma possível fonte de fagos temperados, responsäveis por falhas na produção de àcido láctico, durante o processamento de queijos (LAWRENCE et alii, 1976). A incidéncia praticamente universal de lisogenia nessas bactérias indica que as mesmas podem servir como um reservatörio de fagos potencialmente capazes de atacar as cepas que compõem cs fermentos läcticos mistos (HUGGINS e SAN NE, 1977). Além aisso, ALLEN et alii (1963) demonstraram que podem ocorrer trocas genéticas mediadas por fagos nas bactérias 
läcticas, sendo este um outro fator que pode contribuir para aumentar a variabilidade das linhagens correspondentes daqueles fermentos. Por este motivo, o conhecimento de linhagens lisoge ê. nicas e indicadoras, que possibilitem a multiplicação dos fagos liberados, é muito importante na escolha de uma cultura componente de um fermento láctico.

Com este propósito, os 21 estreptococos läcticos que apresentaram diferentes perfis de plasmidios, foram submetidos à irradiação por meio de luz U.V. (i tem 4.10.), no intui to de induzir seus possíveis profagos ao ciclo litico. Foram utilizadas dosagens de $20 \mathrm{~J}^{-2}$ para induzir 17 culturas e $60 \mathrm{J.m}^{-2}$ para as restantes, pois nem todas as culturas puderam ser induzidas com a primeira dose.

A indução dos fagos temperados foi evidenciada por um clareamento no meio de cultura contendo as culturas induzidas, em comparaça com as testemunhas não submetidas à irradiação U.V. Este clareamento ainda foi comprovado por medidas contínuas em espectrofotómetro da densidadeöptica (0.0.) de todas as culturas. Esses resultados são exemplificados pela Figura 6 .

Todés as culturas sofreram lise entre 90 minutos e 4 horas após o choque com U.V. Procurou-se, em seguida, culturas sensiveis aos fagos temperados presentes nos lisados obtidos. Para tanto, testou-se a ação destes ültimos sobre as mesmas 21 culturas estudadas e tambëm sobre 6 culturas da coleção 
110

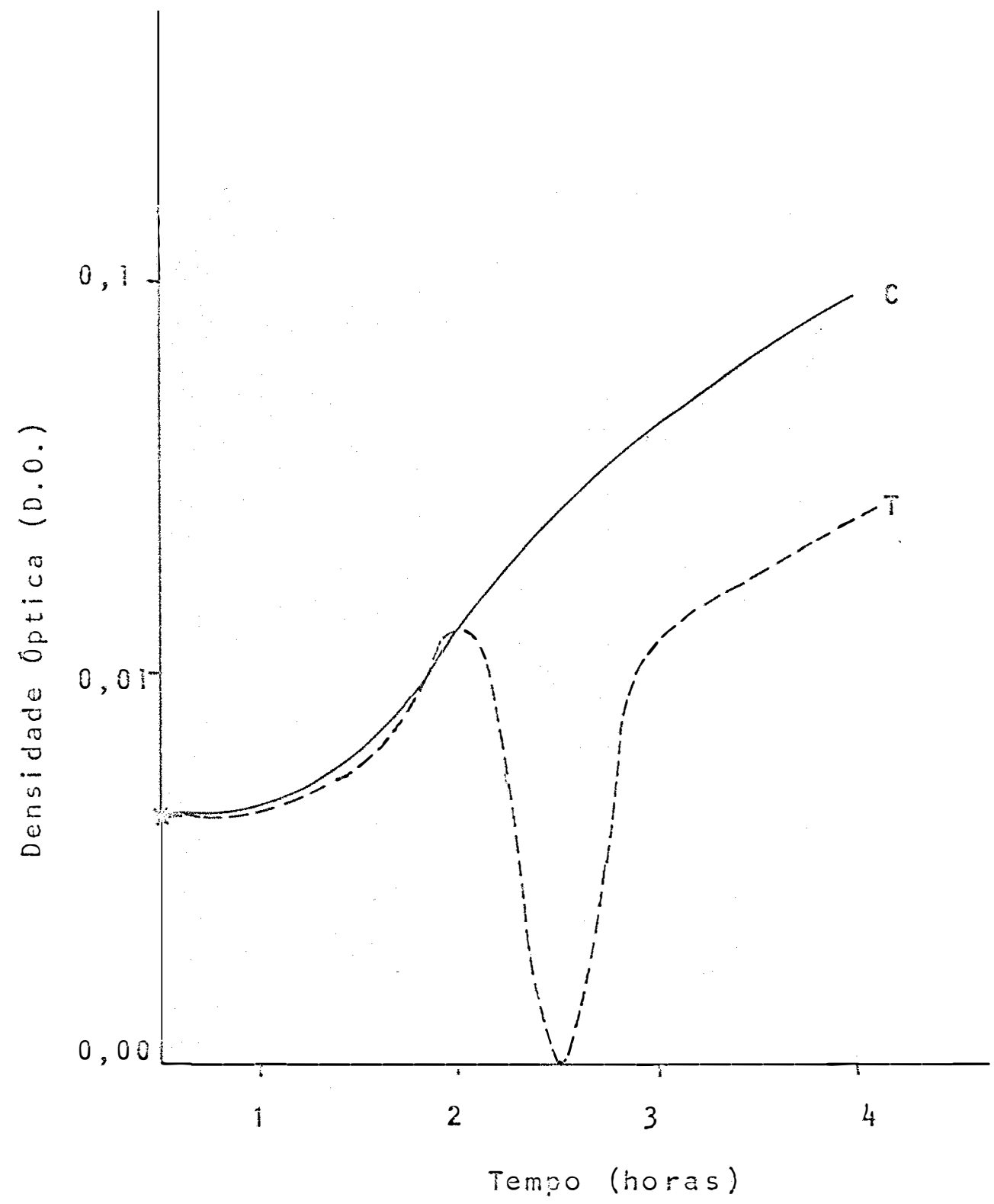

FIgURA 6. Evolução da densidade öptica da linhagem 96 com e sem (c) indução com uma dose de $20 \mathrm{j.m}^{-2}$ de rádiação U. V. 
do INRA, que ja havian se revelado boas indicadoras no curso de un trabatho anterior (REYROLLE abi, 1932). Os resultados obtidos estao sumariados na Tabela VIIH.

TABELA VIII. Espectro lítico de fagos liberados após indução com luz ultravioleta.

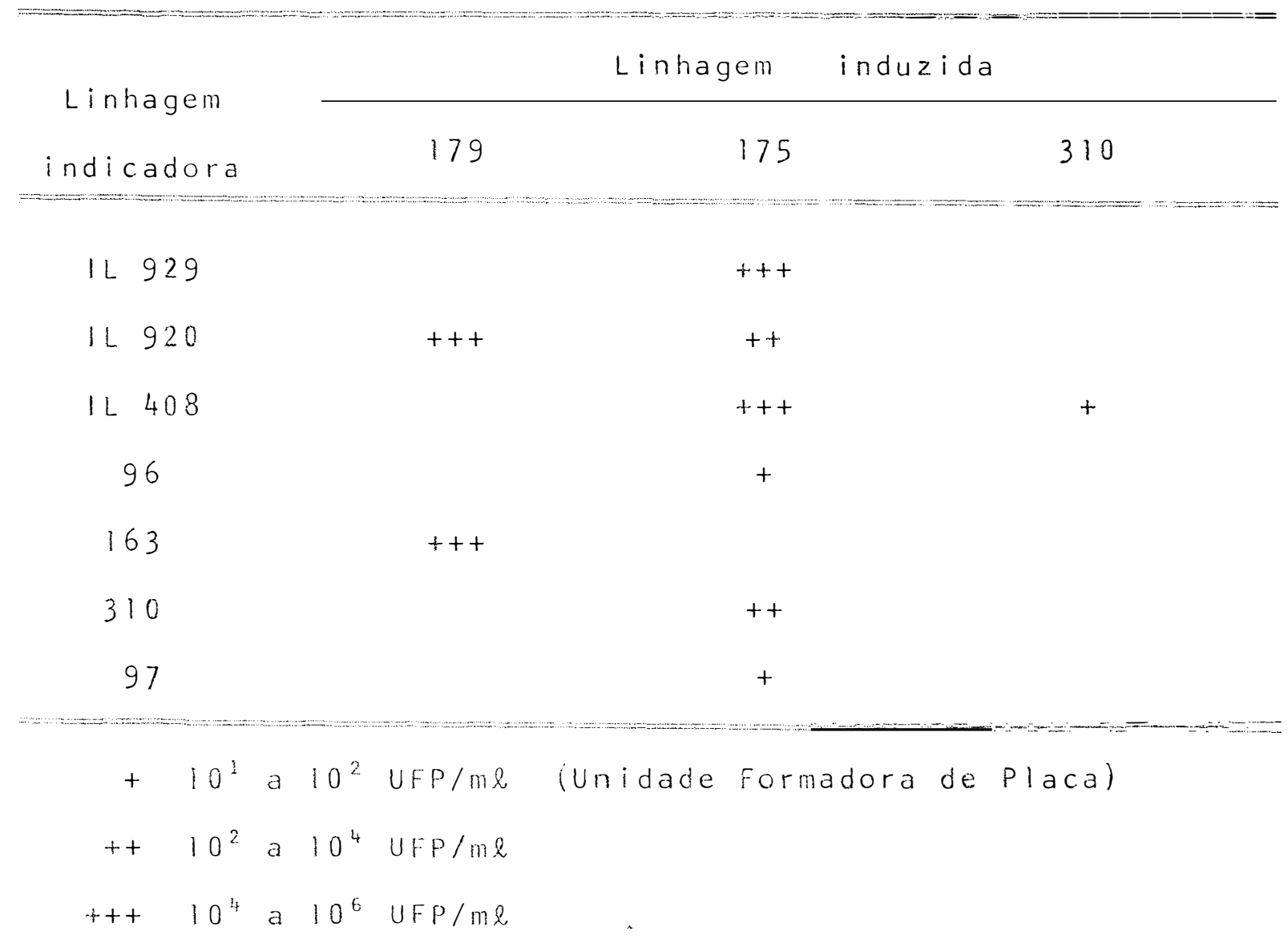

Os lisados obtidos foram, inicialmente, testados pelo mëtodo de gotas, contra todas as 21 culturas em estudo, alëm de 6 culturas indicadoras pertencentes aos grupos G1, G2 e 
G3 (REYrolle et alii, 1982). Quando odtinha-se um resultado po sitivo testava-se, posteriormente, as mesmas culturas e lisados pelo método de plaqueamento em dupla camada. Dessa forma, obte ve-se o titulo das unidades formadoras de placa de lise (UFP) de cada lisado, para cada linhagem sensivel.

As culturas indicadoras do INRA, pertencentes aos Grupos 1 e 2, não mostraram sensibilidade a nenhum dos lisados obtidos. Entretanto, pela Tabela VIll pode-se verificar que apenas 3 linhagens indicadoras, IL 929, IL 930 e 11408 , todas pertencentes ao Grupo 63 , as im como $19 \%$ das culturas em estudo, demonstraram sensibilidade a um ou mais fagos liberados por, somente, 3 das culturas induzidas. Por outro lado, obtiveram-se 100\% da indução, medida peio clareamento do meio e pela cur va de crescimento em biofotômetro, indicando que todas as 21 culturas eram lisogênicas. Esses resultados foram superiores aos encontrados por KOZAK et alii (1973) com S. cremonis e $S$. lactis, os quais, apös indução das culturas com U.V., verificaram liberação de profagos em apenas $8 \%$ das 87 culturas testa das. Também HUGgins e SANDine (1977) e DAVIES e GASSON (1981), utilizando-se de mëtodo similar, relataram que $20 \%$ de um total de 69 linhagens e $60 \%$ de 63 linhagens, respectivamente, eram lisogènicas.

$$
\text { DAVIES e GASSON (1984) concluem que a maioria, }
$$
senão todos os estreptococos läcticos são lisogênicos e que as variações nas freqüencias de aparecimento encontradas refletem, provavelmente: os diferentes critērios usados para determinação 
da lisogenia, a subjetividade na interpretação das quedas de densidade óptica encontradas nas curvas de crescimento após in dução, e a dificuldade de se encontrar linhagens indicadoras.

A rara frequiencia de linhagens indicadoras jä hä via sido discutida por LOWR!E e PEARCE (1971 b), LOWR!E (1974), HEAP et alii (1978) e TERZAGHI e SANOINE (1981), apesar de REYROLLE et alii (1982) terem encontrado que $25 \%$ das linhagens testadas serviram como indicadoras. O presente trabalho vem reafirmar a dificuldade de dispor-se de i inhagens indicado ras, pelo fato de não ter sido possível detectar todos os fagos liberados por meio das inhagens usadas. Por outro lado, a existência de linhagens lisogênicas pertencentes somente ao gru po 63 pode refletir, apenas, como discutido por REYROLLE et alie (1982), o pequeno tamanho da amostra, além da não disponi bilidade de uma linhagem indicadora especifica para os grupos 64,65 e 66 .

Confirmou-se, também, uma especificidade na reação litica entre o fago temperado e a bactéria, pois, todos os profagos originados de culturas do grupo G3 foram capazes de lisar somente linhagens deste mesmo grupo, de acordo com a classificação anteriormente feita em relação aos fagos virulen tos. Dentre elas, a maioria trata-se de $S$. lactis $(310,163,175$ e 179), algumas não tēm espēcie identificada sendo, portanto, Streptococcus sp. (96, 97 e 105) e uma é S. lactis subsp. diacetylactis $(162)$ (Tabela $(x)$. 
A I iberação de fagos foi, para a maioria das linhagens sensiveis, mut to intensa, situando-se entre $10^{4}$ a $10^{6}$ particulas por mililitro. Estes resultados foram semelhantes aos obtidos por REYRolle et alik (1982) por meio de indução com mitomicina $C$.

As linhagens que jà haviam sido classificadas com base na sua sensibilidade aos fagos virulentos são lisogēnicas, sendo os fagos temperados liberados apös induçäo com U.V. per tencentes ao mesmo grupo de sensibilidade. Esta correlação entre fagos temperados e virulentos jà foi comprovada também a nivel morfolögico, por TEUBER e LEMBKE (1982). Ademais, confir ma a hipötese de LAWRENCE ot alié (1978) de que não se deve misturar, nos fermentos lácticos, linhagens sensiveis aos fagos das demais culturas componentes do mesmo.

Dessa forma, de acordo com os resultados obtidos, na elaboração de fermentos mültiplos ou mistos, a partir das culturas aqui estudadas, não se poderia misturar as linhagens $96,163,310$ ou $97 \mathrm{com}$ a 175 e a i inhagem $163 \mathrm{com}$ a 179 . Isto significa que as linhagens lisogénicas podem constituir-se em reservatório de fagos virulentos, capazes de lisar as linhagens sensíveis, ou sofrer mutação contra seu próprio hospedeiro, podendo ocasionar problemas graves durante os processamentos de queijo (MCKAY e BALDWIN, 1973; LAWRENCE et alie, 1976; HUGGINS e SANDINE, 1977 e REYROLLE ot arii, 1982).

Finalizando, a indução das linhagens lisogênicas 
e o espectro litico de seus profagos permitirama classificação das culturas 96, 97 r 175 no grupo G3 (Tabela $1 X$ ), coisa que não foi possível fazer por meio do teste com fagos virulen tos, assim como confirmou a classificação anteriormente feita por aquele método, para as culturas 310,163 e 179. Este fato corrobora a validade e aplicação da classificação proposta por CHOPIN et alie (1976) para culturas läcticas provenientes de diferentes origens.

TABELA $1 X$. Agrupamento dos estreptococos lácticos pertencentes à coleção do ITAL, de acordo com a classificação proposta por CHOPIN et alii (1976) e REYROLLE et alii $(1982)$.

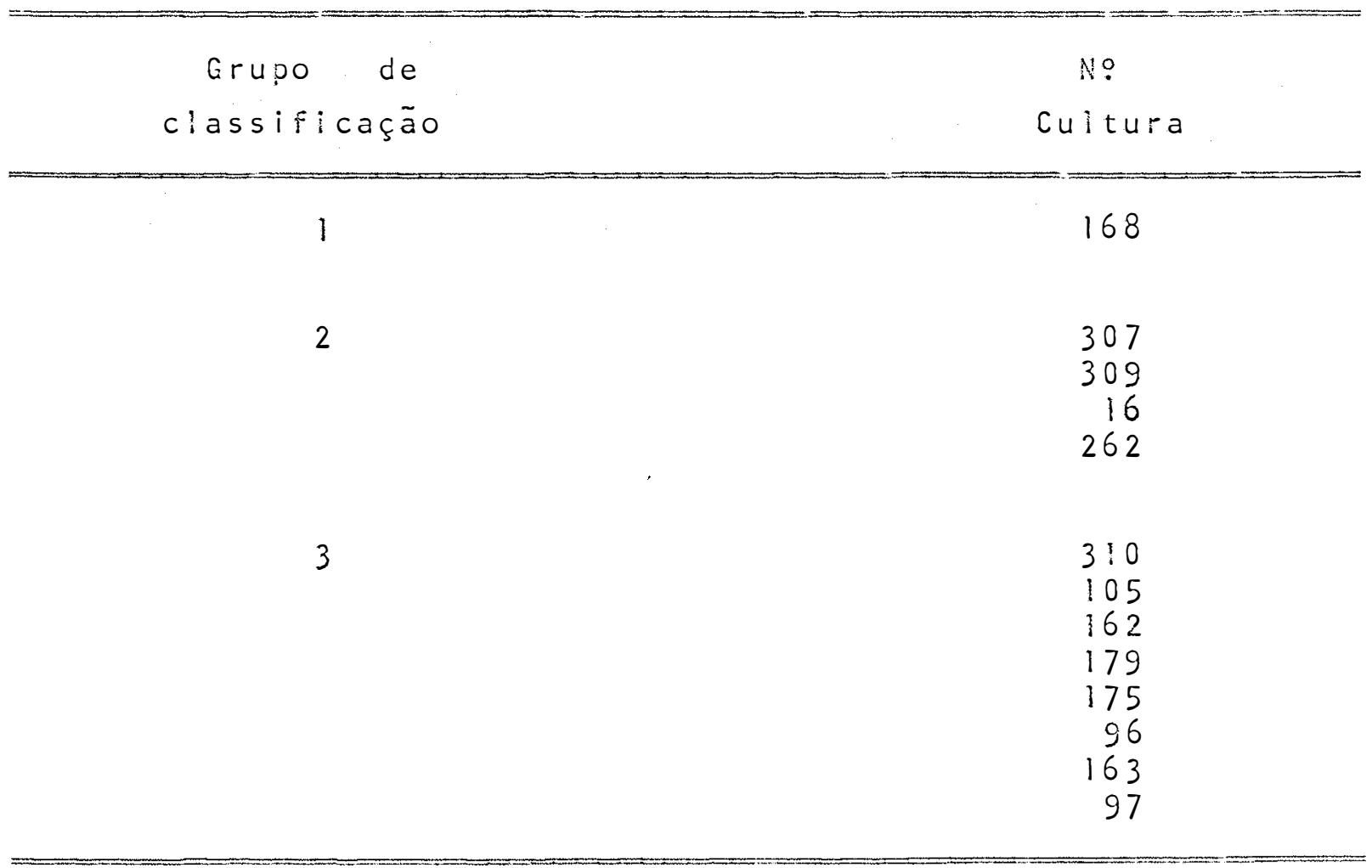


5.6. Estudos beitos com o Streptococcus cremoris, linhagem 839 , pertencente à coleşão do INRA

\section{6.i. Evidencia de um sistema de restrifão/mo- dîtıą̧a}

Foi COLLINS (1956) quem demonstrou pela primeira vez a existência de sistemas de restrição e modificação nos es treptococos lácticos. Por esses sistemas, quando O DNA do bacteriófago penetra na célula bacteriana, esta o destrói, por meio da ação de uma endonuclease capaz de cortar o DNA em sítios e pecificos, a menos que os mesmos tenham sido previamente modificados pela ação de uma metilase ou glicosidase e, assim, pro tegidos da ação das enzimas de restrição. Neste ültimo caso, - fago realiza seu ciclo lítico normal (KRÜGER e BICKLE, 1983).

A evidencia bioguímica da existência dessas enzi mas nos estreptococos lácticos foi fornecida por fITZGERALD et alii (1982) quando do isolamento de uma endonuclease de restri fão do tipo 11, em S. cremoris.

A existência de sistemas de R/M nos estreptococos lácticos já está bem estabelecida sabendo-se, atualmente, que os mesmos estã̃o amplamente distribuidos neste gênero de bactérias, podendo existir, mesmo, värios sistemas diferentes de R/M na mesma linhagem (BOUSSEMAER et alii, 1980; DALY e FITZGERALD, 1982; DAVIES e GASSON, 1981, 1983; MCKAY, 1983 e CHOPIN et alii, 1984). 
Evidenciou-se, neste trabalho (Tabela $x$ ), que o S. cremoris linhagem $\| \mathbf{L} 839$, possuía um sistema de restrição de 5 log em relação ao fago 8, quando este era multiplicado so bre 1 835, sua linhagem original de propagação. Quando o fago era propagado sobre IL 839, esta modificava-o, não mais restringindo-o. Desde que propagado novamente sobre 12835 , o fago perdia a modifícaça adquirida quando de sua passagem por iL 839, a qual passava a restringi-lo novamente, também em 5 $\log$ como no estoque original, indicando que um sistema de $R / M$ estava envolvido.

Estudou-se, a seguir, a base genética desse sistema de R/M encontrado em $1 L 839$.

5.6.2. Caracterizaçäo e determinaçäo do peso molecular dos plasmidios de $S$. cremoris 12839

o estudo da biologia de plasmidios tem se tornado "importante área de investigação nas bactérias lácticas jä que numerosas caracteristicas fermentativas e metabólicas, incluindo a resistência a fagos, de grande instabilidade em al guns desses organismos, estäo ligadas a genes localizados em plasmidios (KEMPLER e McKAY, 1981; MCKAY, 1982, 1983; CROW et alii, 1983; DAVIES e GASSON, 1983; GASSON, 1984; DAVEY, 1984 e MCKAY E BALDWIN, 1984).

Assim, a fim de conhecer a constituição de plasmídios da linhagem IL 839, o mesmo foi determinado por meio de eletroforese do DNA obtido por extração alcalina (item 4.14.1.) e confirmado por eletroforese bidimensional (item 4.16.) (Figura 7). 
TABELA $X$. Evidência da presença de um mecanismo de $R / M$ em $S$. chemoris IL 839, ativo sobre o fago 8 .

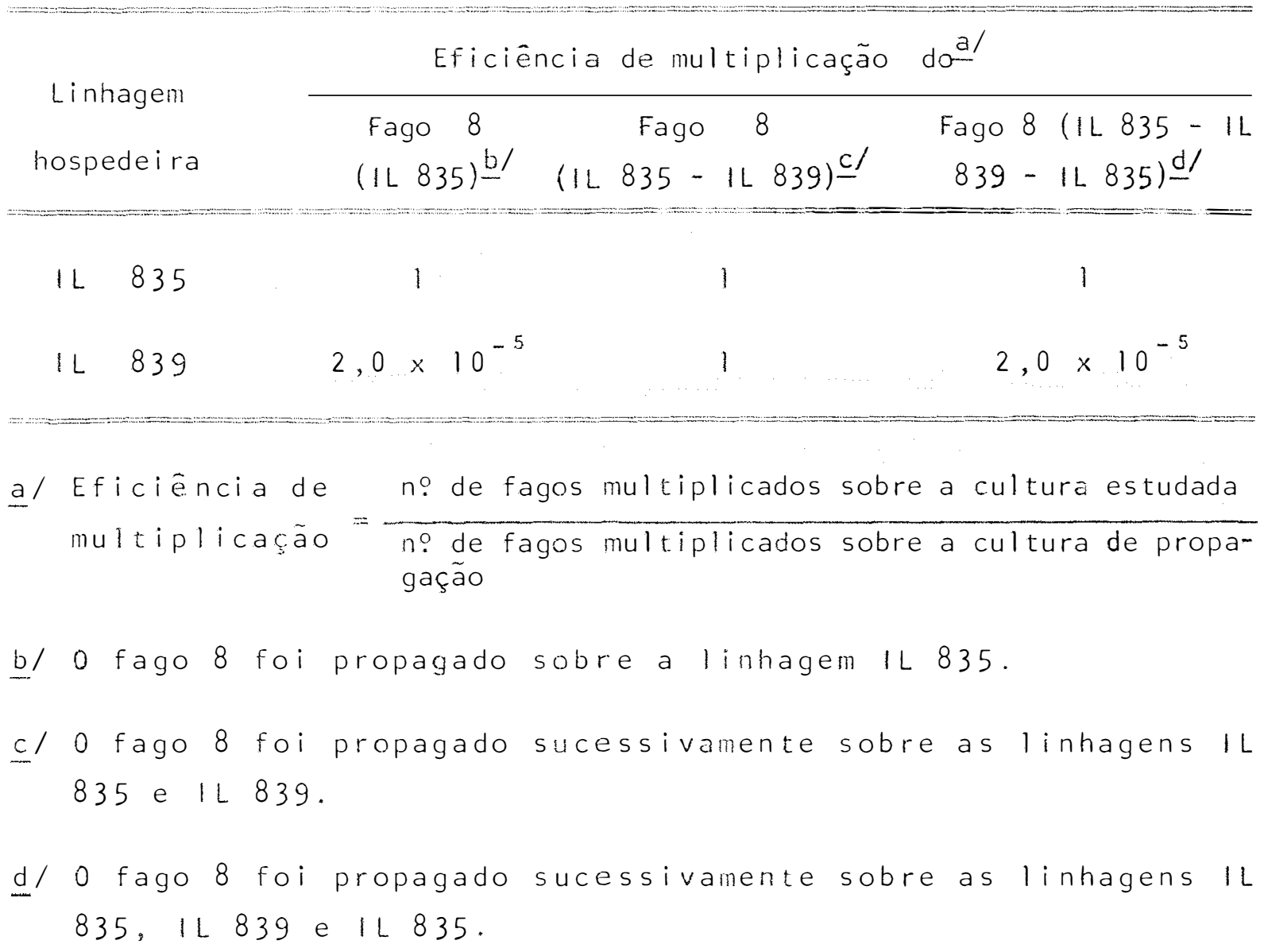


Após sua extração, os plasmídios que normalmente estão sob a forma super-espiralada (CCC) são, algumas vezes, quebrados, podendo-se enconträ-los, então, sob a forma relaxada (OC) ou mesmo sob a forma linear (L). A eletroforese bidimensional permite recuperar as bandas correspondentes ao DNA plasmidial søb a forma CCC, as quais devem, inicialmente, ser levadas em conta na determinação de perfil de plasmídios da cul tura.

A técnica de extração utilizada neste trabalho, entretanto, não altera o DNA; conseqüentemente, todas as formas observadas correspondem a plasmidios sob a forma CCC. Assim, a cultura IL 839 possui 8 plasmidios que foram denominados PIL 20 a PIL 27 .

os pesos meleculares dos • ito plasmidios da linhagem IL 839 foram estimades por cálculo, utilizando-se a meLodoløia de MEYERS etalii(1976) (item 4.17.). Para tanto, foram incluidos n• mesmo gel de eletroforese, juntamente com IL 839, os seguintes plasmidios de pesos moleculares conhecidos: p8R 322, pVA $749 \Delta$ e pVA 856 (item 4.2.) e os plasmídios de S. lactis IL 1437 (CHOPIN et alii, 1984). A Figura 8 mostra os resultados •btides.

$$
\text { Estimaram-se os tamanos des plasmídios }
$$

PIL 20 a pIL 27 com $\bullet$ sendo, respectivamente, de 3, 5, 6, 9, 14, 15,17 e $46 \mathrm{~kb}$. 
Eletroforese do extrato

plasmidial de IL 839

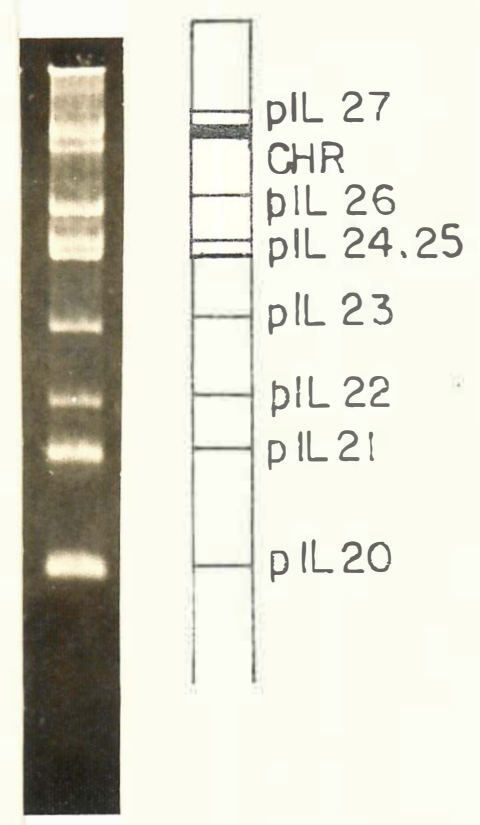

Eletroforese bidimensional (a)

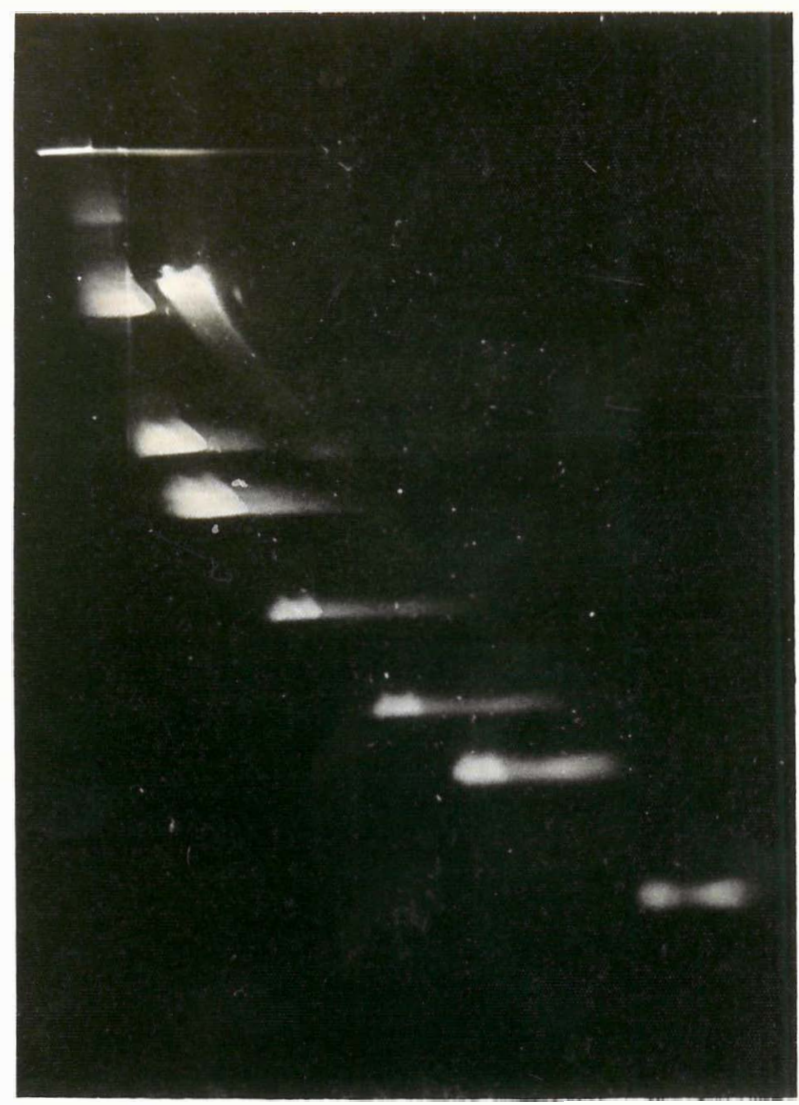

FIGURA 7. Perfil e eletroforese bidimensional dos plasmídios de S. Chemoris IL 839. (a) Legenda: - DNA plasmidial sob a forma super-espiralada (CCC); DNA cromossómico. 

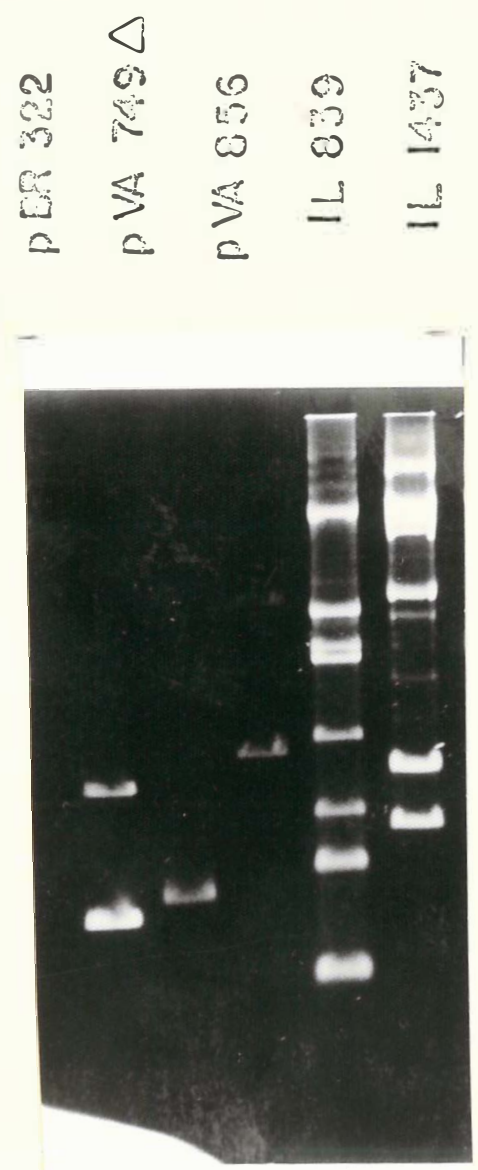

FIGURA 8. Eletroforese horizontal dos plasmidios PBR 322 , PVA 7494, PVA 856, de IL 839 e de IL 1437. 
5.6.3. Localização dos genes que codificam o sis tema de restrição/modifícação presente em S. cremonts IL 839

5.6.3.1. Plasmidios.

(a) Cuta de plasmídios

Pesquisou-se, inicialmente, se o sistema de R/M presente em IL 839 era codificado por um dos 8 plasmídios presentes nesta l inhagem. I sto porque, de um lado, sabe-se que as principais propriedades tecnolögicas dos estreptococos läcticos são codificadas por plasmídios, como já citado anteriormen te e, por outro lado, há diversas evidencias na literatura que associam as perdas de sistemas de R/M à frequências correspondentes à perda de plasmídios (LIMSOWTIN et alie, 1978; SANDERS E KLAENHAMMER, 1980, 1981; TEUBER e LEMBKE, 1983 e CHOPIN et alii, 1984). Jä foi evidenciado, também, que alteraçöes nas propriedades de adsorção dos estreptococos lácticos podem ser devidas, em alguns casos, à aquisiçăo ou perda de plasmídios (SANDERS C KLAENHAMMER, 1983 e DE VOS et alii, 1984).

A fim de determinar se o sistema de R/M de IL 839 estava relacionadc a um ou a värios dos seus plasmídios, os mes mos foram eliminados um a um, por meio da técnica de regeneração de protoplastos (GASSON, 1983). Foram obtidos 16 tipos de variantes, tendo todos perdido pelo menos um dos 8 plasmídios (Figuras 9 e 10 ) presentes na linhagem original. Não foi possí vel obter, entretanto, a cura do plasmidio $1 / 21 \mathrm{em}$ nenhum dos variantes. 


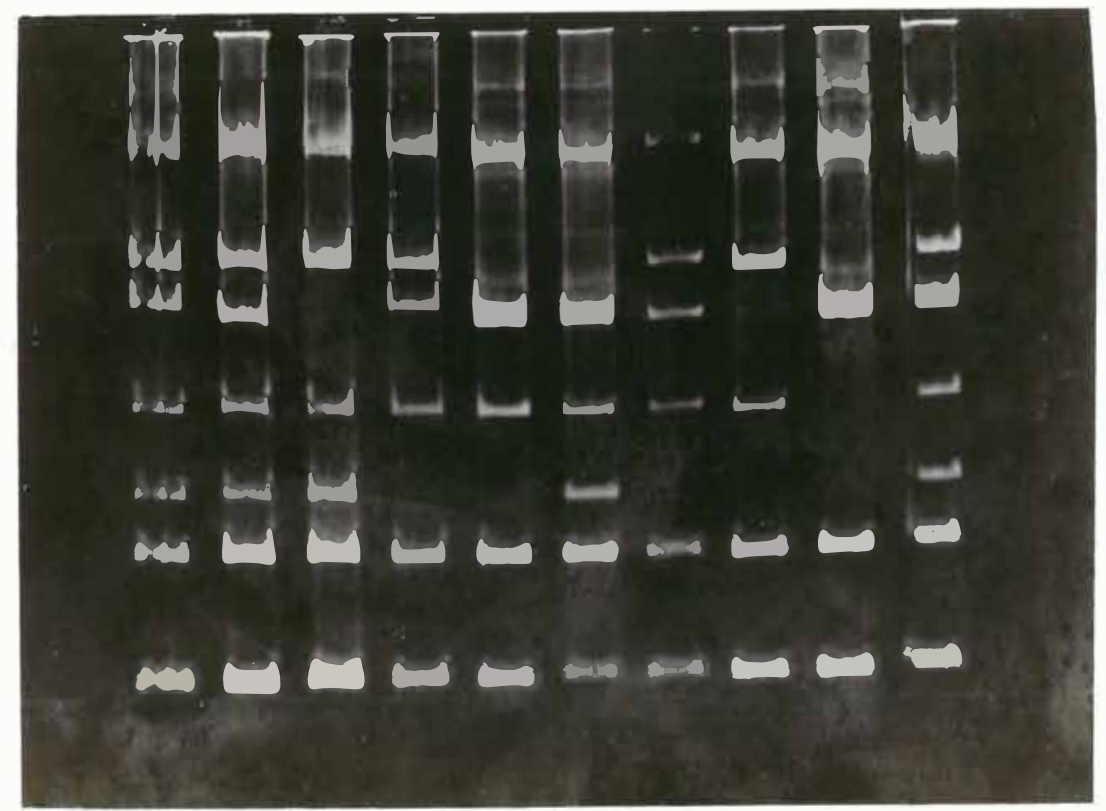

FIGURA 9. Perfis de plasmídios de variantes de S. cremoris IL 839 obtidos pela cura de plasmídios. 


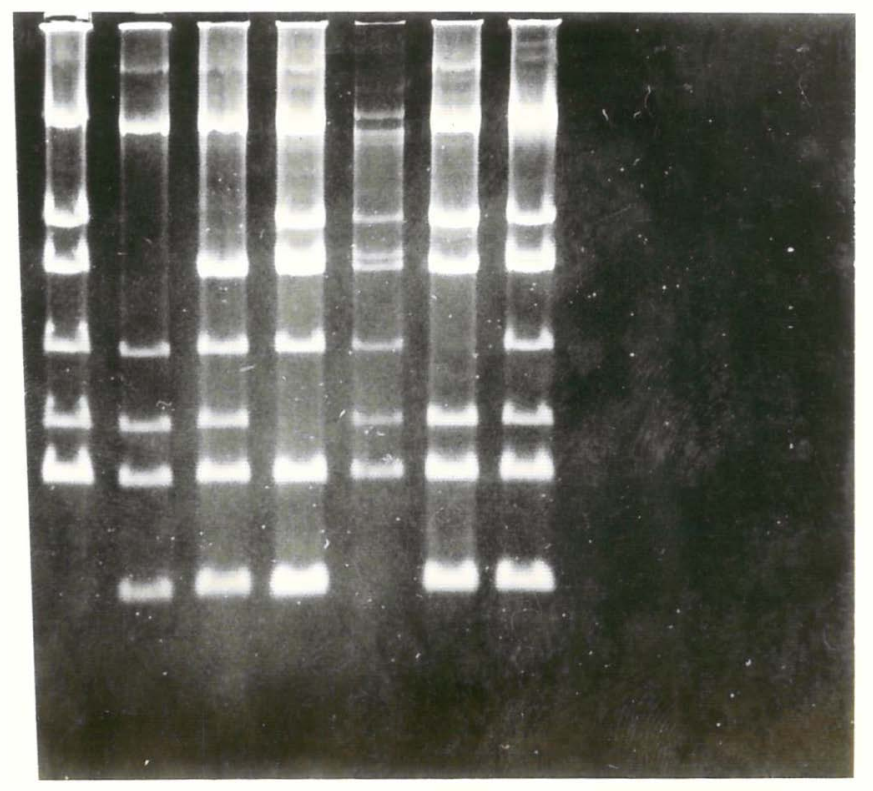

FIGURA 10. Perfis de plasmidios de variantes de S. cremoris IL 839 oblidos pelo cura de plasmídios 
A técnica de regeneração de protoplastos já utiI izada por CHOPIN ot alie (1984) e GASSON (1984) resultou em excelente método de cura de plasmídios pois, por meio dela, po de-se estabelecer o papel de 7 dos 8 plasmídios presentes em IL 839 em relação à base genética do sistema de R/M. Todos os variantes obtidos apresentavam resistência idêntica à linhagem original. Isto indica que nenhum dos 7 plasmidios eliminados codificava o sistema de R/M em IL 839.

(b) Preparação do plasmídio pIL 21 por recuperação a partir de um get de agarose

A fim de estabelecer se o plasmídioplL 21 tinha alguma função no mecanismo de R/M I inhagem $1 \mathrm{~L} 839$, foi introdü zido em Streptococcus lactis I inhagem IL 1403 Iivre de plasmidios (CHOPIN et alii, 1984). Dessa forma, efetuou-se, inicial mente, uma preparação do plasmídio plL 21 , a qual foi transfe rida, posteriormente, para a linhagem IL 1403, pela técnica de cotransformação juntamente com um plasmidio indicador, pHV 1301 , contendo marca de resistência à eritromicina (item 4.2.).

o conteüdo plasmidial da linhagem IL 839 foi extraido em grande cuantidade (item 4.14.2.) e submetido a uma eletroforese preparativa em gel de agarose vertical (item 4.15.). As Figuras 11 e 12 apresentam os plasmidios antes e apös recuperação da banda referente ao plasmídio pIL 21.

Pela Figura II pode-se observar que os diferentes plasmídios estão presentes no gel, tanto sob as formas CCC como OC. 


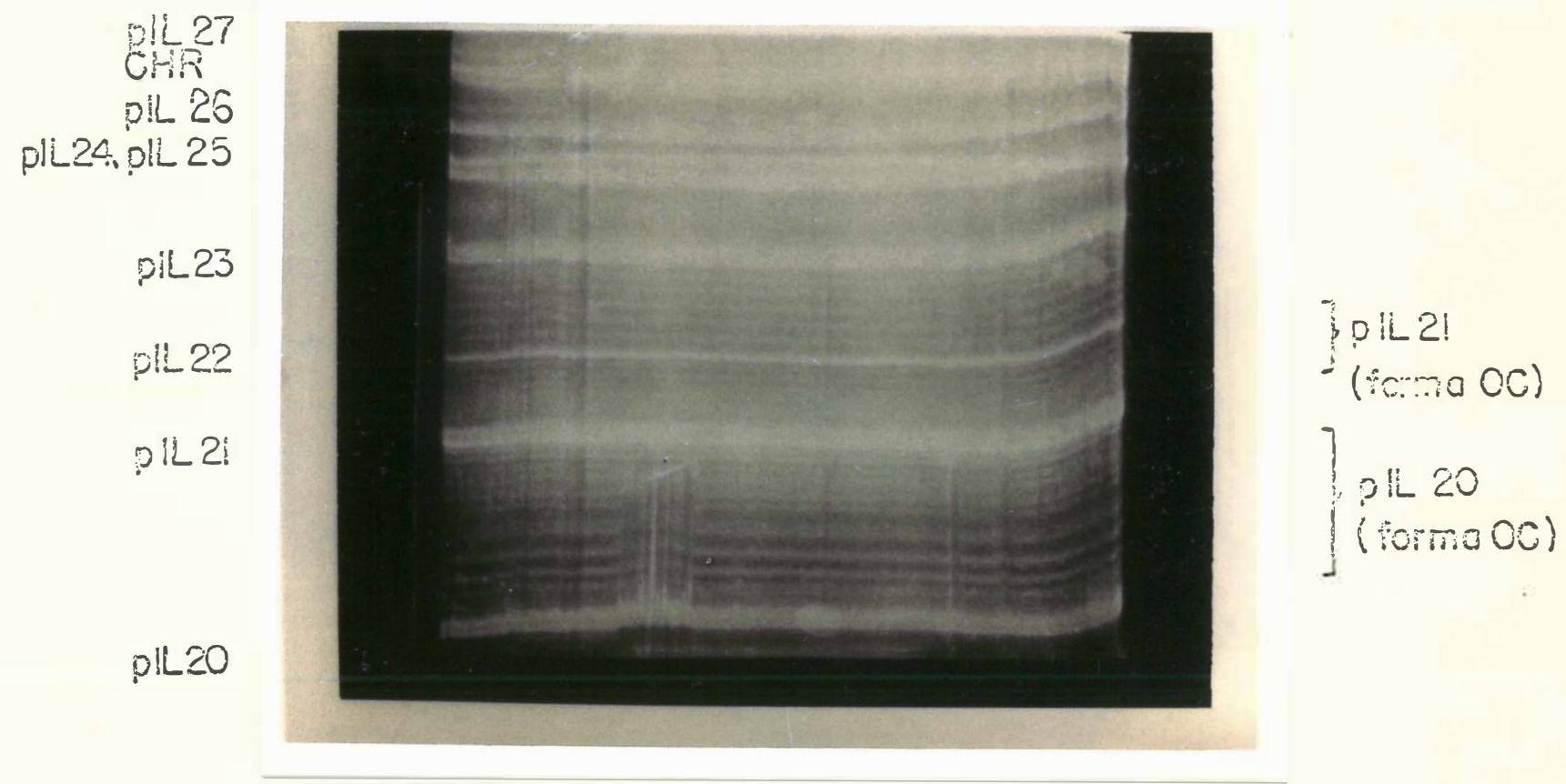

FIGURA 11. Eletroforese vertical de uma extração preparativa dos plasmídios de IL 839. 


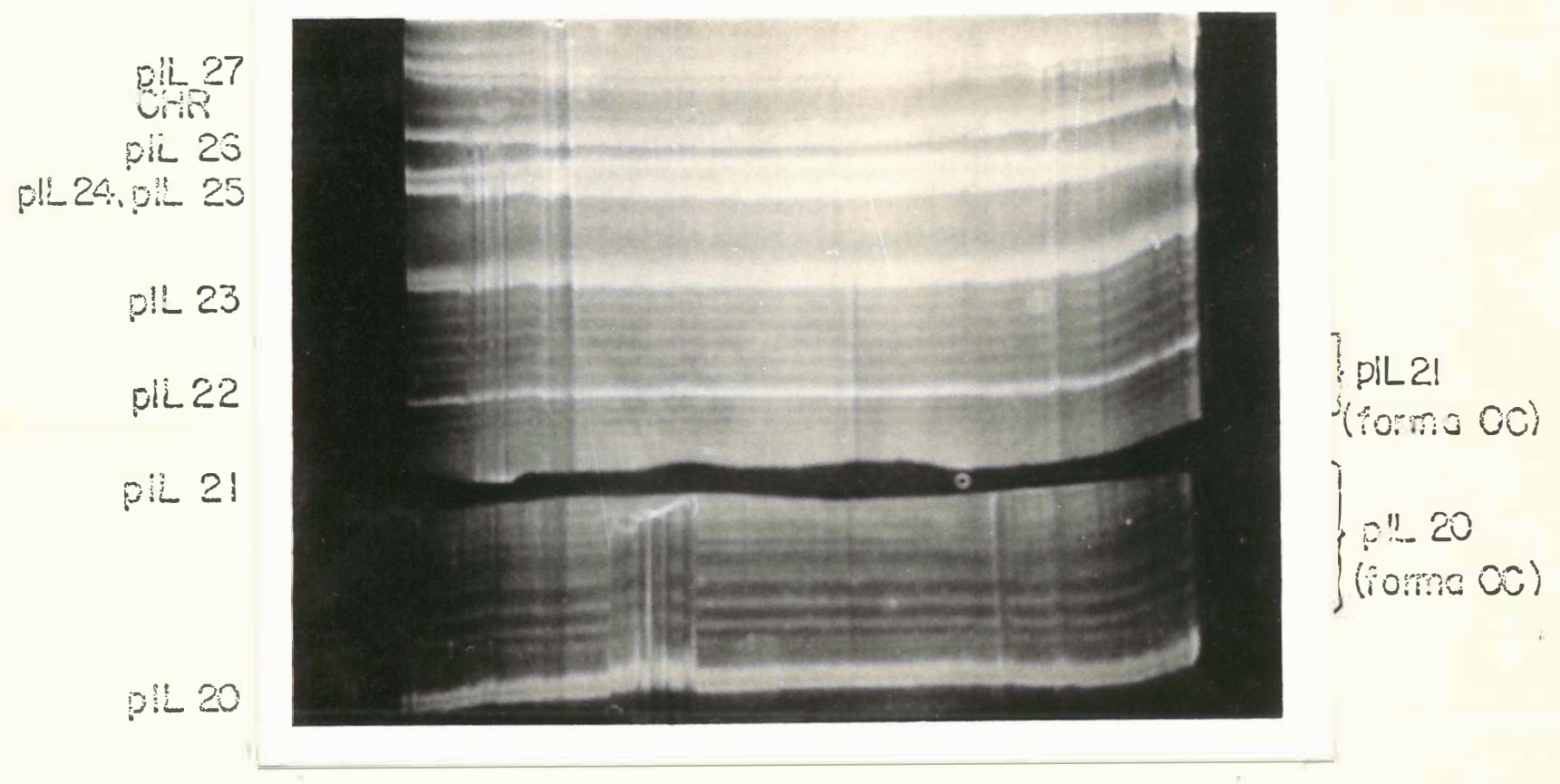

FIGURA 12. Eietroforese vertical de uma exíraço preparativa dos plasmidios de IL 839 , ápós recorte da banda re lativa ao plasmidio piL 2 l. 
o pIL 21 foi recuperado a partir da banda recortada do gel de agarose (Figura 12), a qual foi submetida a um processo de eletro-eluição (item 4.19). Essamistura de DNAs, contendo as formas CCC do pIL 21 e as formas $0 C$ de pIL 20 e p IL 21, foi utilizada para o experimento de transformação (item 4.26.).

\section{(c) Transferéncia do plasmidio pIL 21 por co- thans jotmaçäa}

Muitos plasmídios encontrados em bactērias läct cas, como op IL 21 de S. chemoris 1 L 839, permanecem cripticos pela impossibilidade de introduzi-los em linhagens adequadas para investigações genëticas. Este problema tem sido resolvido em outras espécies de microrganismos por meio da aplicação do método de cotransformação de uma linhagem bacteriana competente, utilizando-se dois plasmidios diferentes, sendo um deles selecionável (KRETSCHMER et alii, 1975 e MACRINA et alie, 1980). Uma técnica similar, adaptada aos S. lactis por SIMON et alii (1985) permitiu que se estudasse a função do plasmídio pIL 21 na base genética do sistema de R/M de IL 839.

A transformação de $S$. lactis $1 \mathrm{~L} 1403$ foi feita com 0,2 $\mu \mathrm{g} / \mathrm{ml}$ de phV 1301 e $0,08 \mu \mathrm{g} / \mathrm{ml}$ de pIL 21 , ou seja, a mis tura de DNA obtida como descrito anteriormente. Foram obtidos $2,7 \times 10^{5}$ transformantes resistentes à eritromicina por micrograma de pHV 1301. Apōs uma seleção feita do conteūdo plasmidial de 100 transformantes resistentes à eritromicina (Em ${ }^{r}$ ), 
que possuím o pHV 1301, obtiveram-se: 73 transformantes que continham apenas o pHV 1301; 2 transformantes que continham 0 pHV 1301 eplL 21; I continha o pHV 1301, p!L 21 e plL 20, e 24 transfor mantes que possuíam pHV 1301 e plL 20 . Estes dois ültimos resultados obtidos devem-se a fato de que o plasmidio pll 20, mesmo sob a forma oc, transformou com alta eficiência a linhagem $1 \mathrm{~L} 1403$.

O plasmídió indicador pHV 1301 segrega espontaneamente. Dessa forma, após a lgumas repicagens sucessivas, iso laram-se cotransformantes que haviam perdido o pHV 1301 e conservado, unicamente, o plasmidio p!L 21 (Figura 13).

Os cotransformantes que possuiam apenas o plasmí dio pIL 21 foram testados contra os fagos 66 e 67 (virulentos contra a cultura transformante), observando-se que não haviam adquirido o sistema de restrição/modificação, mostrando-se, por tanto, sensiveis aos bacteriöragos.

Estes resultados indicaram, portanto, que o plas mídio. p/L 21 , assim como os outros testados, também rão codif $\underline{i}$ cava o sistema de R/M presente em S. cremoris $I L 839$, não sendo este ültimo, ciessa forma, de natureza plasmidial, mas sim, determinado por genes localizados no cromossomo. Estes fatos evidenciam, pela primeira vez, um sistema de R/M sendo codificado por genes cromossômicos em bactérias läcticas.

\section{6 .3 .2 . Cromossomo.}

A fim de isolar os genes cromossomais que codifi cam o sistema de R/M em S. cremoris IL 839 era necessärio 


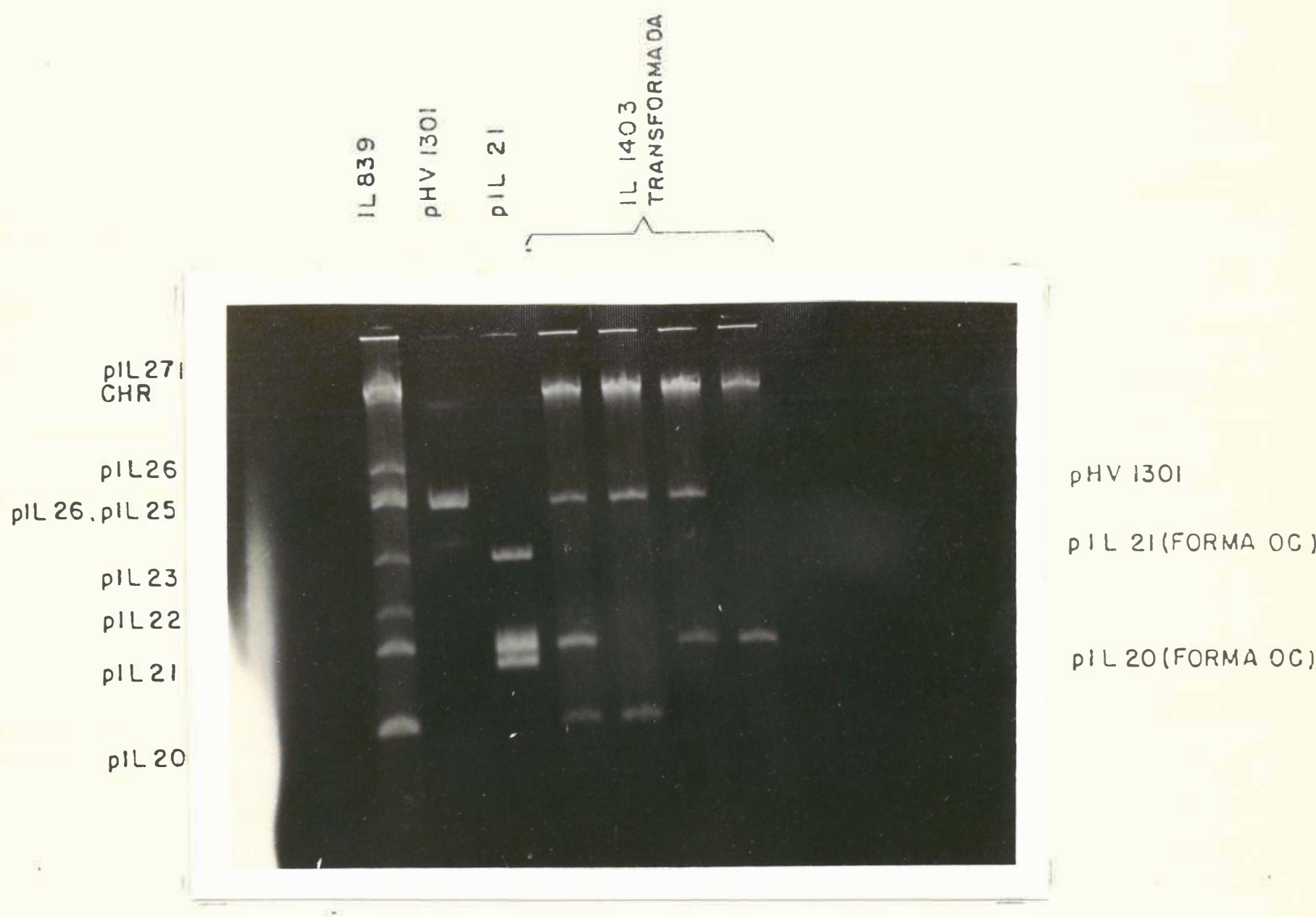

FIGUaA 13. Transferéncia de um plasmidio criplico de S. cremisis 12839 paras. Ractis 1L 1403, por cotransfor. $\operatorname{riaçōo.~}$ 
utilizar-se técnicas de engenharla genética. Para tanto, deveria dispor-se de: (i) um método que permitisse cortar e religar os DNAs de origens diferentes; (2) vetores de clonagem, ou sejam, fragmentos de DNA capazes de replicarem-se na célula hospedeira após terem sofrido a inserf̧ã̃o de um outro dNA estranho a ele; (3) um método que possibilite a penetrą̧ão do DNA hibri do na célula hospedeira dentro da qual possa replicar-se como a transformação e (4) uma técnica de deteç̧ão das céiulas que continham e que replicaram aquele DNA recombinante em estudo, contendo os genes procuracios.

No caso das bactérias läcticas pode-se, a priori, pensar em utilizar os plasmídios vetores já desenvolvidos para outras bactérias Gram +, como estreptococos, estafilococos e Bacilqus (CLEWELL et alii, 1974, MACRINA et alii, 1980, BEHNKE et alii, 1982 e kok et alii, 1984), alguns já utiliza dos com sucesso na clonagem de genes plasmidiais (KONDO e MckAY, 1984 e CHOpln et alii (Appl. Environ. Microbicl.), em publicafão) ou em construílos novamente inserindo genes de resistencia a antibióticos em pequenos plasmídios de bactérias lácticas.

o problema maior, até pouco tempo, situava-se ao nível de introdução do DNA recombinante na bactéria por transformação. Os primeiros rendimentos de transformação de protoplastos de $S$. Lactis obtidos por KONDO e MckAY (1982, 1983), a partir da täcnica descrita por CHANG e COHEN (1979) foram da ordem de 10 transformantes por micrograma de DNA. Eles eram muito 
baixos para permitir a clonagem mesmo de genes plasmidiais. Os mesmos alitores (1984), assim como s!Mon et alii (1985) conseguiram aumentä-las para $10^{4}$ transformantes por micrograma de onA. Estes üt tmos rendimentos permitiam a clonagem de genes plasmidiais sendo, entretanto, alnda insuficientes para objeti. var a clonagem de genes cromossómicos.

Posteriormente, entretanto, o laboratório de ChOPIN (informação pessoal) obteve resultados de transformação com frequências da ordem de $10^{6}$ a $10^{7}$ transformantes por micrograma de DNA. Estes rendimentos permitiam a clonagem de genes cro mossômicos (ou clonagem "shotgun"), a partir do ONA celular total.

(a) Extração preparativa do ONA cromossômico de S. cremoris IL 839

Para clonar os genes responsáveis pelo sistema de $R / M$ presente em $S$. cremoris $1 L 839$ havia necessidade primei ramente, de se extrair em grande quantidade o DNA cromossômico daquela linhagem. Assim, O ONA cromossomico da linhagem IL 839 foi extraído de acordo com a metodologia descrita no item 4.22. Efetuou-se, posteriormente, uma eletroforese horizontal desse DNA extraido, juntamente com O DNA do fago $\lambda$, a fim de quantificá-lo. Obteve-se, dessa forma, um extrato cromossomico contendo $400 \mu \mathrm{g} / \mathrm{ml}$ de DNA.

(b) Digestão parcial do cromossomo de IL 839 por Hoa II 
Para obtar fragmentos menores de DNA passiveis de serem clonados, realizou-se uma digestão parcial do cromos somo. Escolheu-se a digestão parcial aumentando-se o tamanho dos fragmentos a serem clonados e aumentando-se, conseqüentemente, a probabilidade de clonar o fragmento procurado. Ademais, havia a possibllidade de que os genes codificando o sistema de R/M do IL 839 possuissem un tamanho superior a 4 kb, ou seja, - tamanho médio que se obtém quando de uma digestão total do ONA (NALCOM, 1981 e MANIATIS et aliR, 1982).

Para digerir o DNA cromossomico de lL 839 utilizou-se a enzima de restrição Họa ll por ser a única que permite efetuar-se lima digestão parcial, por meio do reconhecimento de uma seqüencia de 4 nucleotídios (MANIATIS et alii, 1982).Por outro lado, o vetor escolhido, pVA $749 \Delta$ possitia um sitio de corte para esta enzima.

Determinou-se, primeiramente, qual a diluição conveniente de enzima a ser utilizada para obter uma digestão par cial do cromossomo (Figura 14). Através de eletroforese vertical em gel de agarose, tendo como testemunha o DNA do fago $\lambda$ digerido pela enzima Hind 111 , pode-se determinar que com 0,5 Ul de Hpa li por microlitro obtinha-se a digestão parcial desejada do cromossomo de IL 839. Objetivou-se, nesse caso, uma digestão tal onde se obtivesse essencialmente fragmentos possuindo entre 10 a $20 \mathrm{~kb}$. Efetuou-se, a seguir, a digestão, porém de uma quantidade maior de cromossomo, ou seja, $250 \mu g$, ut lizando-se 0,5 Ul de Hpa por microlitro. 


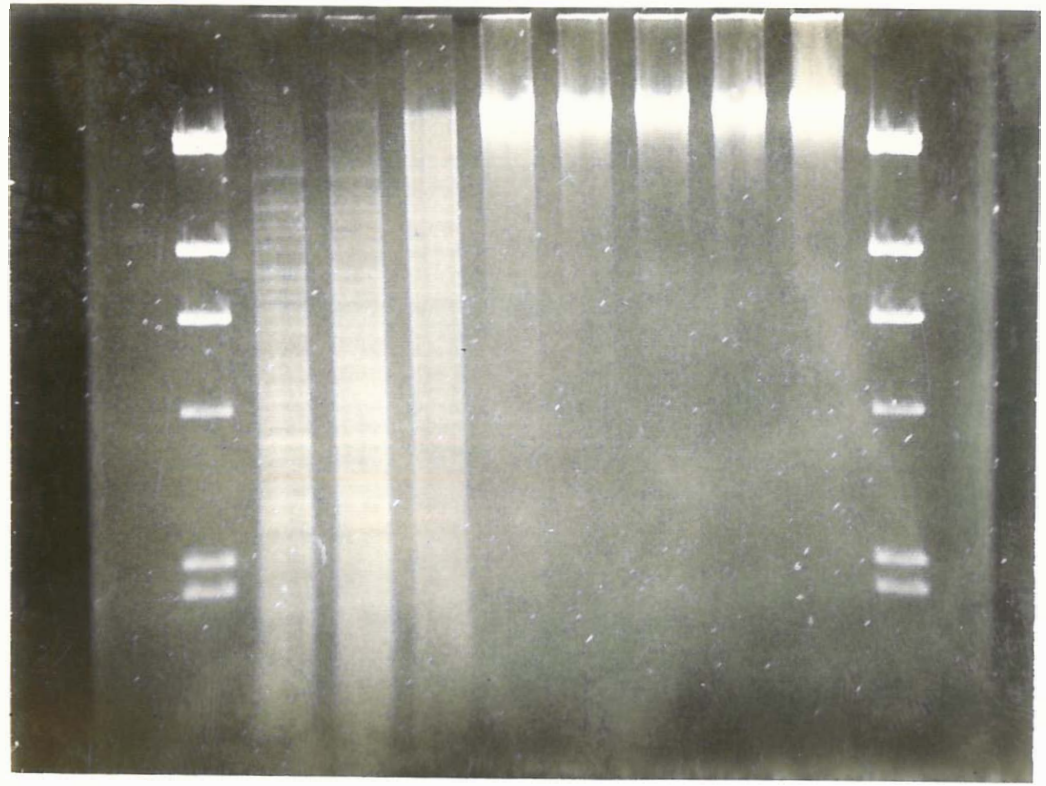

FIGURA í. Digestão parcial do cromossomo de ll 839 por hpa 11. 
(c) Seleção por tamanho dos hragmentos cromossomais de IL 839

Em experimentos preliminares, imediatamente apös a digestão parcial do cromossomo realizava-se a iigação com o plasmidio vetor, sem resultados positivos após transformação. Assim, declidu-se fazer uma seleção por támanho, em gradiente de sacarose, dos fragmentos de DNA cromossômico obtidos (item 4.24.). Foram coletadas aliquotas de aproximadamente $100 \mu 2$ e $5 \mu l$, de cada 3 frações, foram submetidas a eletroforese vert cal, a fim de selecionar os fragmentos de tamanho desejado (10 a $20 \mathrm{~kb})$, os quais foram utilizados na fabricaçäo do DNA recombinante. A Figura 15 mostra alguns dos resultados obtidos.

Como não se conhecia exatamente o tamanho dos ge nes que codificam o sistema de $R / M$, os quais se desejava cionar, seguiu-se orientação baseada no trabalho de GlNáras e BRooks (1983). Estes autores alonaram um fragmento de plasmidio de Pseudomonas aeruginosa de $7,6 \mathrm{~kb}$ codificando para uma determinada atividade de $R / M$. Após terem diminuido o tamanho do mesmo para, aproximadamente, $5 \mathrm{~kb}$, obtiveram tanto os genes que codificavam o sistema de restrição, como aqueles de $\bmod i f i c a c ̧ a ̃ o$.

A técnica utilizada no presente trabalho apresen tou o inconveniente de selecionar fragmentos com tamanhos di $\underline{s}$ persos, de 5 kb a mals de $20 \mathrm{~kb}$. Assim, a seleção por tamanho dos fragmentos cromossônicos estä sendo feita, atualmente, no 


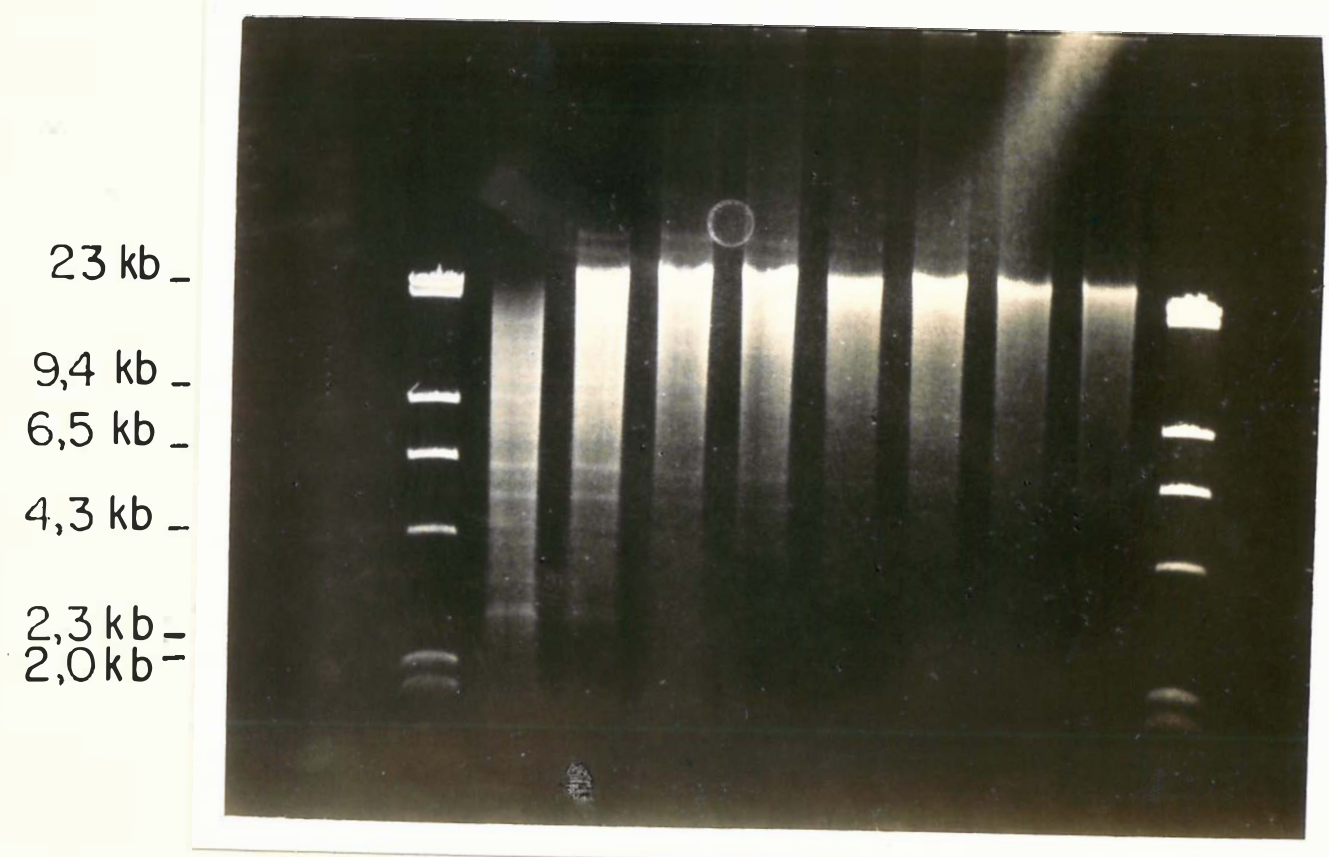

FIGURA 15. Eletroforese vertical dos fragmentos obtidos poi digestão parcial do cromossomo IL 83 y após passagem por gradiente de sacarose. 
laboratorio do INRA, por melo de eletroforese preparativa, a qual permite, cortando-se o gel, eliminar todos os fragmentos de tamanho superior ou inferior a um determinado limite.

\section{(d) Fabricaf̧ão do DNA recombinante}

O DNA recombinante utilizado para transformar $1 L$ 1403 fol fabricado a partir dos fragmentos de cromossomo obtídos como descrito no item anterior, e o plasmídio vetor pVA $749 \Delta$ igualmente cortacio com a enzima Ho 11 (item 4.21.). 0 DNA recombinante obtido apōs ligação (item 4.25.) pode ser ob servado na Figura 16.

O DNA recombinante assim produzido fo: utilizado para a sransformą̧ão de $S$. lactis 11 1403.

\section{(e) Thans formação}

Efetuou-se a transformação de $S$. lactis IL 1403 Com O DNA recombinante fábricado como citado no item 4.25., seguindo-se metodologia descrita por slMon et alii (1985).

Apös incubação durante 7 dilas, para regeneração dos protoplastos, 100 colónias crescidas em placas contendo $M 17+61 i+5 \mu g$ de eritromicina por mililitro foram repicadas para tubos contendo o mesmo meio, na forma liquida.

A partir daí efetuaram-se dois testes: (1) plaqueamento das colónias em presença dos fagos 66 e 67 , para verificação da possivel aquisição dos genes responsávels pelo 
(a) (b) (c)

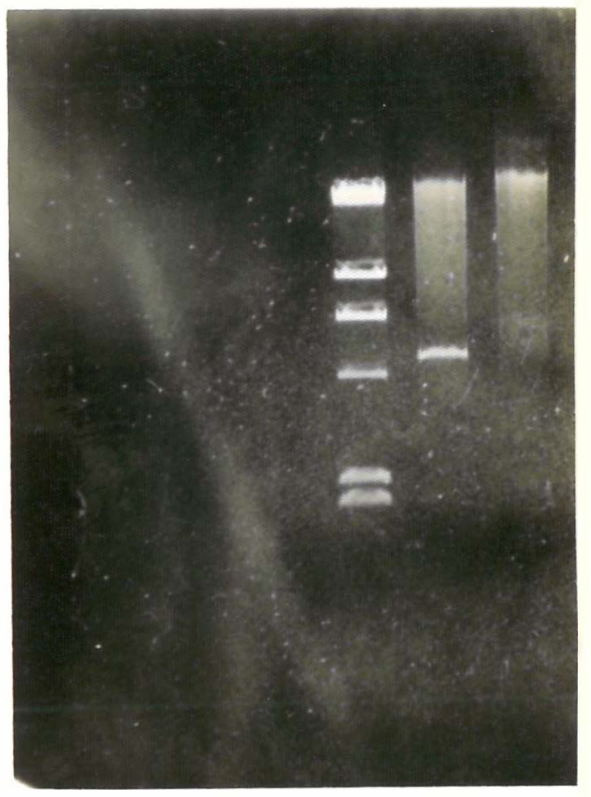

FIGURA 16. DNA recombinante formado pelo cromossomo de $S$. che moris IL 839 e pelo plasmidio pVA 749 4 . (a) DNA do fago $\lambda$ digerido por Hind 111 ; (b) cromossomo IL 839 e pVA $749 \Delta$ digeridos por Hpa 11, antes de ligação; (c) cromossomo IL 839 e pVA 749 digeridos por Hpa II, apōs ligação. 
sistema de R/vi e (2) extração dos plasmídios de todos os ciones para verificar se havia uma banda correspondente a fragmento cromossômico inserido no DNA recombinante.

observou-se que nenhum dos 100 clones havia adquirido resistência aos fagos ensaiados, signiflcando que o fragmento cromossomico contendo o gene que codifica o sistema de R/M em S. chemonis IL 839 não havia sido transformado. Ade mais, um exame do conteúdo plasmidial dos transformantes evidenciou gue menos de l\% dos clones havia adquirido o plasmidio pVA 7494, sendo que nenhum deles apresentava uma inserção.

Experimeritos reallizados por outros membros do laboratório da Dra. M. - C. CHoplN, em Renies, França, mostraram que a ausância de uma inserção não resultava de um defeito na fabricação do DNA recombinante, mas, que ela é devida à natureza do vetor utilizado. Outros vetores como pHV 1301 Ou pGK 12, manipulados nas mesmas condiçoses permitiramobter-se, aproximadamente, $10 \%$ de clones que possuiam O DNA recombinante, sendo esta a Frequência normal.

Conciulu-se, assim, que o vetor pVA $749 \Delta$ não con vêm a este tipo de experimento, por não poder se manter na lI nhagem IL 1403 quando possui um fragmento de DHA a ele inserido. Atë o momento nenhuma hipótese válida pode ser elabora da para explicar o fato de que pVA $749 \Delta$ funcione bem em $S$. sanguis (challis) e não em S. Lactis. 
O grupo da Dra. CHOPlin, portanto, construiu um vetor, a partir do piasmidio pHA 130$\}$ (13 kb), possuindo um tamanho reduzido para $5,5 \mathrm{~kb}$. Este vetor obtido transforma S. lactis com rendimentos de $3,0 \times 10^{2}$ transformantes por mi crograma de DNA. A este pequeno vetor foi inserido um "poly linker", ou seja, um fragmento de DNA contendo 82 pares de bases que contēm 12 sitios de restrição, aproximadamente, fa cilitando, enormemente, a técnica de clonagem. 
5. CONCLUSÕES

os principais objetivos do presente trabalho foram: (1) caracterização de culturas pertencentes à coleçãode Fermentos Läcticos do ITAL quanto a crescimento em diferentes temperaturas, Tiberação espontânea ou induzida de bacteriófagos e perfil de plasmídios e (2) estudo da base genética de um sistema de restrição e modificação em S. cremoris $1 L$ 839 com o propósito de clonà-lo.

De acordo com os resultados obtidos, pode-se tirar as seguintes conclusões:

(a) Somente 17 dentre 124 culturas läcticas do TTAL não conseguiram crescer a $23^{\circ} \mathrm{C}$ durante 18 horas, demons trando não serem boas acidificantes; 
(b) As culturas läcticas do ITAL mostraram maior atividade acidificante apōs incubação a $30^{\circ} \mathrm{C}$ durante 90 min e $38^{\circ} \mathrm{C}$ durante mais 4 horas, evidenciando serem, na sua maio ria, do tipo räpidas ("fast");

(c) Apenas duas culturas, 166 e 280, liberaram espontaneamente bacteriöragos, näo devendo, portanto, serem ut ilizadas em processamento;

(d) De 58 culturas läcticas do ITAL, estudadas quanto à biologia de plasmícios, 21 apresentaram perfis diferentes, com nümerovariado de plasmidios e as restantes apresentaram um dos 6 tipos de perfis anälogos;

(e) Todas as 21 culturas apresentando perfis de plasmidios diferentes são lisogênicas, liberando profagos apōs indução com luz ultravioleta. Pôde-se determinar por e te mëtodo que não se deve misturar, em fermento misto, as cul turas $96,163,310$ ou $97 \mathrm{coma} 175$ e a linhagem 163 com a 179

(f) De acordo com a sensibilidade a fagos virulentos e profagos liberados apōs indução, as culturas läcti cas brasileiras estudadas puderam ser classificadas da seguinte forma: grupo $G_{1}=168 ;$ grupo $G_{2}=307,309,16$ e 262 e grupo $G_{3}=310,105,162,179,163,96,97$ e 175:

(g) As culturas 310 e 162 apresentaram um sistema de restrição de 4 log e 2 log, respectivamente, em relação aos fagos virulentos 66,67 e 188 para a primeira e 66 
para a segunda. A resistencia apresentada pelas linhagens 105 a 162 eni relação ao fago 188 corresponderam a mutações sofridas por este üitimo;

(h) OS. chemoris il 839 apresenta um sistema de restriçãolmcdificação de $5 \log$ em relação ao fago 8 . Nenhum dos 8 plasmidios presentes nesta linhagem codifica este siste ma de resistência, sendo o mesmo codificado por genes situados no cromossomo;

(i) Na tentativa de clonar os genes cromossomais de R/M de IL839 (cionagem "shotgun") utilizando-se do vetor pVA 749 4 , apesar da transformação do DNA recombinante ter ocor rido, não foi possivel isolarem-se clones transformantes pelo fato do vetor não se expressar em S. iactis IL 1403, Iinhagem transformada, quando ligado a um outro fragmento de DNA. 
144

7. SUMMARY

This work was done with two main purposes: to obtain a better characterization of lactic streptococci belonging to the Food Technology Institute (ITAL-Brazil) Collection of Lactic Starters, and (2) to study the genetic determination of a phage resistance system found in $S$. cremoris strain IL 839, belonging to a Collection of Lactic Cultures of the National Institute of Agronomic Research (INRA-France), with the objective of cloning it.

$$
\text { It was found that among } 124 \text { lactic bacterial }
$$
cultures belonging to ITAL collection, only 17 failed to grow during 18 hours at $23^{\circ} \mathrm{C}$, being this the first selection performed with mesophylic lactic cultures. These cuitures resisted weli to cooking temperature without alteration of their 
actdifing activities and only two strains, 166 and 280 , sponteneously released their bacteriophages and were therefore not recommended as lactic starters.

Among the lactic cultures from this collection, 2 out of 53 showed profiles of plasmids while in the remaining 37, 6 types of analogue profiles were observed. All cultures that showed different profiles were found to be lysogenic, releasing prophages after exposure to ultraviolet light. The lyc tic sprectrum showed that based on virulent phages and on prophages released, one can classify the cultures in three groups: $G_{1}=\operatorname{strain} 168 ; G_{2}=$ strains $307,309,16$ and 262 and $G_{3}=$ strains $310,96,97,105,163,175,179$ and 162 . 1t was also observed that the cultures 310 and 162 showed restriction and modification systems of $4 \mathrm{log}$ and $2 \mathrm{log}$, in relation to phages 60,67 and 188 in the first case, and 66 for the second, respectively.

The S. chemoris 14839 showed a restriction and modification system of $5 \log$ in relation to phage 8 . It was found that this strain had 8 plasmids termed pIL 20 to pIL 27 , with seizes of $3,5,6,9,14,15,17$ and $46 \mathrm{~kb}$. The protoplas tization method enabled the curing of plasmids and showed that none were related to the $R / M$ system. The plasmid $P I L 21$, not cured was cotransformed with the plasmid pHV 1301, used as a marker for erythromycine resistence, in S. lactis $1 \mathrm{~L} 1403$, not provided with plasmids. It was found that the cotransfomed 
culture also falled to acquired the R/M system. It was concluded that the system was codified by genes present on the chromosome.

A partial digestion of the chromosome was performed with the restiction enzyme Hpa 11 , selection of fragments by size in a sucrose gradient followed by ligation to the vector plasmid pVA $749 \Delta$ which harbours a resistant mark for erythromycine, and was linearized by the same enzyme. Cells of S. lactis 11 1403 transformed by this recombinant ONA had only the vector plasmid probably because the fragment insertion prevents it of surviving in this line. 
AEd-el-Malek, y. e T. CIBSON, 1948. Studies in the bacteriology of milk. 1. The streptococci of milk. Jounnal of Dairy Research, 15: $233-248$.

ACCOLAS, J.-P., D. HEMME, M.J. DESMAZEAUd, I. VASSAL, C. BOUILLANNE e M. VEAUX, 1980. Les levains lactiques thermophiles: propriétés et comportement en technologie laitière. Une revue. Le Lait, 60: 487-524.

ACKERMAN, H. -iN., 1969. Bactériophages: propriétés et premières étapes, d'une classification. Revue générale. Pathologie-Biologie, 17: 1003-i024.

ADAis, N.H., 1950. Bacteriophages. New York, Interscience Publishers, Inc., p. $454-456$. 
ALLEN, L.K., W.E. SANOINE e P.R. ELLIKER, 1963. Transduction in Streptococcus lactis. Journal of Dairy Research, 30: 351-357 .

ANderson, O.G. e L.L. MickAY, 1977. Plasmids, loss of lactose metabolism, and appearance of partial and full lactose-fermenting revertants in Streptococcus cremoris $B_{i}$. Journal of Bacteriology, 129: 367-377.

ANDERSON, D.G. e L.L. MCKAY, 1983. Simple and rapid method for isolating large plasmid DNA from lactic streptococci. Applied and Environmental Microbiology, 45: 549-552.

ANDERSON, D.G. e L.L. McKAy, 1984. in vivo cloning of lac genes in Streptococcus lactis ML3. Applied and Environmental Microbiology, 47: 245-249.

ANDERSON, D.G., D.H. OHLENDORF, Y. TAKEDA E B.W. MATTHEWS, 1981. Structure of the cro repressor from bacteriophage $\lambda$ and its interaction with DNA. Nature, 290: 754-758.

ANTUNES, L.A.F., 1985. Caracterização da flora läctica de leite cru. Campinas, UN!CAMp, $113 \mathrm{p}$. (Tese de Doutoramento).

ARBER, W., 1974. DNA modification and restriction. Progress in Nucleic Acid Research and Molecular Biology, 14: 1-37.

AUCLAIR, J. e J.-P. ACCOLAS, 1983. Use of thermophilic lactic siarters in the dairy industries. Antonie van Leeuwenhoek, $40: 313-326$. 
AUSAVANODOM, N., R.S. WHITE, G. YOUNG E G.H. RICHARDSON, 1977. Lactio buik culture system utilizing whey-based bacteriophage inhibitory medium and pH control. H. Reduction of phosphate requeriments under pH control. Jounnal of Dainy Science, 60: 1245-1251.

SABEL, F.J., 1955. Slow acid production by lactic cultures: A review. Journal of Dairy Science, 38: 705-733.

BABEL, F.J., 1958. New developments in the lactic cultures: cul ture media and bacteriophage inhibition. Journal of Dairy Science, 41: 697-698.

BABEL, F.J., 1962. Industriai utilization. of lactic cultures. Journal of Dairy Science, 45: 1286-1290.

BAUER, H., E. DENTAN E T. SOZZ1, 1970. The morphology of some Streptococcus bacteriophages. Journal of Microscopy, 9: $851-$ $-898$.

BARKSDALE, L. e S.B. ARDEN, 1974. Persisting bacteriophages in fections, lysogeny, and phage conversion. Annual Review of́ Microbiology, 2 8: $265-299$.

BEHNKE, D., M.S. GLLMORE E J.J. FERRETTI, 1982. pGB 301 vectOr plasmid family and its use for molecular cloning in streptococci. In: SCHLESINGER, D., Ed. Microbiology. Washington, D.C., ASN, P. $239-242$. 
BELOVA, G.A., Z.P. MEOVEDEVA, A.N. KORNELYUK E T.F. TROFIMOVA, 1982. Study of some properties of lactic streptococci used in cheesemaking. Dairy Science Abstracts, 44: 455 .

BICKLE, T.A., Iy82. The ATP-dependent restriction endonucleases. In: LINN, S.M. e R.J.ROBERTS, Eds. Nucleases. Cold Spring Harbor Laboratory. New York, Cold Spring Harbor, p. $85-108$.

BOLIVAR, F., R.L. RODRIGUEZ, P.J. GREENE, M.C. BETLACH, H.L., HEYNEKER, H.W., BOYER, J.H. CROSA E S. FALKOW, 1977. CONStruction and characterization of new cloning vehicles. 11 . A multipurpose cloning system. Gene, 2 : $95-113$.

BOTTAZZ1, V., 1979. Microbiologia dei fermenti lattici. Futurgraf, Reggio Enilia, $324 \mathrm{p}$.

BOUSSEMAER, J.P., P.P. SCHRAUWEN, J.L. SOURROVILLE P P. GUY, 1980. Multiple modification/restriction systems in lactic streptococci and their significance in defining a phage- typing system. Journal of Dainy Research, 47: 401-409.

BOYD, J.M. e H.L.A. TARR, 1955. Inhibition of moid and yeast development in food products. Food Technology, 9: 411-412.

BOYER, H.W., 1971. DNA restriction and modification mechanisms in bacteria. Annual Review of Microbiology, 25: 153-176.

BRADLEY, D.E., 1963. The structure of coliphages. Journal of General Microbiology, 31: 435 . 
BRADLEY, D.E., 1905. The morphology and physiology of bacteriophages as revealed by the electron microscope. Jounnal of the Royal Microbiology Society, 84: 257-316.

BRADLEY, D.E., 1967. A review: ultrastructure of bacteriophages and bacteriocins. Bacteriological Reviews, 31: 230 .

BRADLEY, S.G. e L.A. JONES, 1968. Bacteriophages, their biology and industrial significance. Progress in Industrial Microbiology, I: $43-75$.

BRIGGS, C.A.E., 1952. A note on the serological classification of Streptococcus diacetylactis. Journal of Dairy Research, 19: $167-168$.

BRIGGS, C.A.E. e L.G.M. NEWLAND, 1952. The serological classification of Streptococcus cremoris. Journal of Dairy Research, 19: $160-167$.

BRIGGS, C.A.E. e L.G.M. NEWLAND, 1953. Observations on the serological typing of groups $N$ ('lactic') streptococci. Journal of Dairy Research, 20: 18y-197.

BuChANAN, R.E. e N.E. GibBONS, Eds., 1975. Bergey's Manual of Determinative Bacteriology. Baltimore, Waveriy Press, inc. $8^{\text {th }}$ ed., $967 \mathrm{p}$.

CALAM, C.T., 1964. The selection, improvement and preservation of microorganisms. Proghess in Industrial Microbiology, $\underline{5}$ : $1-53$. 
CHANG, S. E S.N. COHEN, i979. High frequency transformation of Bacillus subtilis protoplasts by plasmid DNA. Molecular. and General Genetics, 168: 111-115.

CHEN, Y.L. e G.H. RICHARDSON, 1977. Lactic bulck culture system utilizing whey-based bacteriophage inhibitory medium and pH control. H. Aplicability to cottage cheese manufacture. Journal of Dairy Science, 60: 1252-1255.

CHERRY, W.B. e D.W. WATSON, 1949 a. The Streptococcus lactis host - virus system. i. Factors incluencing quantitative mesurement of the virus. Journal of Bacteriology, 58: 601$-610$.

CHERRY, W.B. E D.W. WATSON, 1949 b. The Streptococcus lactis host - virus system. 11. Characteristics of virus growth and the effect of electrolytes on virus adsorption. Journal of Bacteriology, 58: 611-620.

CHOPIN, A.P. e P. LANGELLA, 1982. Analogies de profils plasmiques chez les streptocoques du groupe N. Le Lait, 62: 705$-719$

CHOPIN, A.P., M.-C. CHOPIN, A. MOILLO-BATT e P. LANGELLA, 1984. Two plasmid - determined restriction and modification systems in Streptococcus lactis. Plasmid, 11:260-263. 
CHOPIN, M.-C., 1980. Resistance of 17 mesophilic lactic Streptococcus bacteriophages to pasteurization and spray-drying. Journal of Dairy Research, 47: 131-139.

CHOP!N, M.-C., A. CHOPIN e C. ROUX, 1976. Definition of bacteriophage groups according to their lytic action and mesophi lic lactic streptococci. Applied and Environmental Microbiology, 32: $741-746$.

CHOPIN, M.-C. e M. ROSSEAU, 1983. Tubular heads in bacteriophages from lactic streptococci. Applied and Environmental Microbiology, 45: 294-296.

CHOPIN, M.-C., A. ROUAULT e M. ROUSSEAU, 1983. Elimination d'un prophage dans des souches mono - et multilysogènes de streptocoques du groupe $N$. Le Lait, 63: 102-115.

CHOPIN, M.-C., A. MOILLO-BATT e A. ROUAULT, 1985. Plasmid-mediated U.V. - protection in Streptococcus lactis. FEMS Microbiology Letters, 26- 243-245.

CHRISTENSEN, V.W., 1972. Recent developments in starter techniques. Dairy Industry, 37: 655-671.

CITTI, J.E., W.E. SANDINE e P.R. ELLIKER, 1965. Comparison of show and fast acid producing Streptococcus lactis. Journal of Dairy Science, 48: 14-18. 
CLEWELL, D.B., Y. YAGI, G.M. DUNNY E S.K. SCHULTZ, 1974. Characterization of three plasmid deoxyribonucleic acid molecules in a strain of Streptococcus faecalis: identification of a plasmid determining erythromycin resistance. Journal of Bacteriologi, 117: 283-289.

COGAN, T.M., 1980. Le levains lactiques mésophiles. Une revue. Le Lait, 60: 397-425.

COLLINS, E.B., 1955. Action of bacteriophage on mixed strain cultures. H1. Strain domination due to the action of bacte riophage and variations in the acid production of secondary growth bacteria. Applied Microbiology, 3: 137-140.

COLLINS, E.B., 1956. Host-controlied variations in bacteriopha ges active against lactic streptococci. Virology, 2: 261-27l.

COLLINS, E.8., 1958. Changes in the bacteriophage sensitivity of lactic streptococci. Journal of Dairy Science, 41: 41$-48$

COLLINS, E.B., 1962. Behaviour and use of lactic streptococci and their bacteriophages. Journal of Dairy Science, 45: 552-558 .

COLLINS, E.B., F.E. NELSON e C.E. PARMELEE, 1950. Acetate and oleate requirements of the lactic group of streptococci. Journal of Bacteriology, 59: $59-74$. 
CORDS, B.R., L.L. MCKAY e P. GUERRY, 1974. Extrachromosomal elements in group iN streptococci. Journal of Bacteriology, $117: 1149-1152$

cox, W.A., 1977. Characteristics and use of starter cultures in the manufacture of hard pressed cheese. Jounnal of the Society of Dairy Technology, 30: 5-15.

CROW, V.L., G.P. DAVEY, L.E. PEARCE e T.O. THOMAS, 1983. PIasmid linkage of the D-tagatose 6-phosphate pathway in Streptococcus lactis: effect on lactose and galactose metabolism. Journal of Bacteriology, 153: 76-83.

CZULAK, J. e B.P. KEOGH, 1957. Trials of phage resisting medium. The Australian Journal of Dairy Technology, 12: 54-55.

CZULAK, J., D.J. BANT, S.C. BLYTHE E J.B. GRACE, 1979. A new cheese starter system. Dairy Industries International, 44 : $17-19$.

OACRE, J.C., 1958. Characteristics of a presumptive Pediococcus occuring in New Zealand Cheddar cheese. Journal of Dairy Research, 25: 409-413.

OALY, $6 ., 1983$. The use of mesophilic cultures in the dairy in dustry. Antonie van Leeuwenhoek, 49: 297-3!2. 
DALY, C. e G.F. FITZGERALD, 1982. Bacteriophage DNA restriction and the lactic streptococci. In: SCHLESSINGER, D., Ed. Mi crobiology-1982. Washington, D.C., American Society for Microbiology, p. 213-216.

DANIELL, S.D. e W.E. SANDINE, 1981. Development and commercial use of a multiple strain starter. Journal of́ Dairy Science, 64: $407-415$.

DAVEY, G.P., 1984. Plasmid associated with diplococcin production in Streptococcus cremoris. Applied and Environmental Microbiology, 48: 895-896.

DAVEY, G.P. e L.E. PEARCE, 1980. The use of Streptococcus cremoris strains cured of diplococcin production as cheese starters. New Zealand Journal of Dairy Science and Techno$\log y$, 15: $51-57$.

DAVIES, F.L. e M.J. GASSON, 1981. Reviews of the progress of dairy science: genetics of lactic acid bacteria. Jounnal of Dairy Research, 48: 363-376.

DAVIES, F.L. e M. GASSON, 1983. Genetics of dairy cultures. Irish Jounnal of Food Science and Technology, I: 49-60. 
DAVIES, F.L. e M.J. GASSON, 1984. Bacteriophages of dairy lactic-acid bacteria. In: DAVIES, F.L. e B.A. LAW, Eds.: Aávances in the Microbiology and Biochemistry of Cheese and Fermented Milk. London, Elsevier Applied Science Publishers, p. $127-151$.

DAVIES, F.L., H.M. UNDERWOOd e M.J. GASSON, 1981. The value of plasmid profiles for strain identification in lactic streptococci and the relationship between Streptococcus lactis 712 , $M L_{3}$ and $C_{2}$. Journal of Applied Bacteriology, 51: 325-337.

DAVIS, J.G., 1965. Cheese. Vol. I: Basic Technology. London, Chur chill, $463 \mathrm{p}$.

DE VOS, W.M., H.M. UNDERWOOD e F.L. DAVIES, 1984. Plasmid encoded bacteriophage resistance in Streptococcus cremoris SK 11. FEMS Microbiology Letters, 23: 175-178.

DUTTA, S.M., R.K. KUILA, B.C. ARORA E B. RANGANATHAN, 1972. Effect of incubation temperature on acid and flavour production in milk by lactic acid bacteria. Journal of Milk and Food Technology, 35: 242-244.

EOOY, D. e V. RAYFIELD, 1978. Frozen concentrated starters for direct inoculation in the cheese vat. In: HULL, R.R., Ed. Factory Derived Cheese Stanters. Proceeding of a meeting or ganised by The Dairy Research Laboratory Division of Food Researci, CSIRO and The Australian Dairy Corporation. Highett, Victoria, Australia, p. 35-38. 
EFSTATHIOU, J.D. e L.L. MickAy, 1976. Plasmids in Streptococcus lactis: evidence that lactose metabolism and proteinase activity are plasmid ilnked. Applied and Environmental Microbiology, 32: $28-44$.

EFSTATHIOU, J.D. e L.L. McKAy, 1977. Inorganic salts resistance associated with a lactose fermenting plasmid in Streptococcus lactis. Journal of Bacteriology, 130: 257-265.

EHRLICH, S.D., B. NIAUDET O B. MICHEL, 1982. In: HOFSCHNEIDER, P.H. e V. GOEBEL, Eds. Gene Cloning in Organisms other Than E. coli. New York, Heidelberg, Berlin. Springer-Verlag, p. 19-29. Apud: SIMON, D., A. ROUAULT e M.-C. CHOPIN. Protoplast transformation of group $N$ streptococci with cryptic plasmids. FEMS Microbiology Letters, 26: 239-241.

ELLIKER, P.R., 1951. The problem of bacteriophage in the dairy industry. Journal of Milk and Food Technology, 14: 13-16.

ENGEL, G., K.E. MILCZWESKI e A. LEMBKE, 1975. Versuche zur Differenzierung von Phagen der Streptococcus lactis-und cremoris - Gruppe: Bakterianspektrum, serologische Beziehungen und morpholigische Kriterien. Kiel. Milchwirtsch. Fors chungsber, 27: 25-47.

ERICKSON, R.J., 1980. APUA: DAVIES, F.L. e M. J. GASSON, 1981. Reviews of the progress of dairy science: genetics of lactic acic bacteria. Journal of Dairy Research, 48: 363-376. 
EXTERKATE, F.A., 1975. The proteolytic system of a slow lactic-acid-producing variant of Streptococcus cremoris HP. Netherlands Milk and Dairy Journal, 30: 3-3.

FITZGERALD, G.F., C. DALY, L.R. BROWN e T. R. GINGERAS, 1982. Serfl: a new sequence - specific endonuclease from Streptococcus cremoris. Nucleic Acid Research, 10: 8171-3179.

foster, e.m., F.e. helson, h.l. SPECK, R.N. dOETSCH e J.C. OlSoN, 1957. Dairy Microbiology. Englewood Cliffs, Prentice- HaIl, Inc., $490 \mathrm{p}$.

FRANkE, A.E. e D.B. CLEWELL, 1980. Evidence for conjugal transfer of a Streptococcus faecalis transposon (TN 916) from a chromosomal site in the absence of plasmid DNA. Cold Spring Harbor Symposia on quantitative Biology, 45: 77-80.

FRyer, F.F. e M.E. SHARpe, 1966. Pediococci in Cheddar cheese. Journal of Dairy Research, 33: 325-331.

FUCHS, P.G., J. ZAYDEL e W.T. DOBRZANSKl, 1975. POSSible plasmid nature of the determinant for production of the antibio tic nisin in some strains of Streptococcus lactis. Journal of General Microbiology, 88: 189-192.

GARCIA, S., 1984. Isolamento e seleção de culturas lä́cticas pạ ra a fabricação de queijos. Campinas, UiniCAMp, 89 p. (Tese de Mestrado).

GASSON, M.J., 1980. Production, regeneration and fusion c? pro toplasts in lactic streptococci. FENS Microbiology Letrers, 9: $99-102$. 
GASSON, M.J., 1983. Plasmid complements of Streptococcus lactis NCDO 712 and other lactic streptococci after protoplast induced curing. Jourval of Bacteriology, 154: 1-9.

GASSON, M.J., Yy84. Transfer of sucrose fermenting ability, nisin resistance and nisin production into Streptococcus lactis 712. FEMS Microbiology Letiers, 21:7-io.

GASSON, M.J. e F.L. DAVIES, 1980 a. Prophage-cured derivatives of Streptococcus lactis and Streptococcus cremoris. Applied and Environmental Microbiology, 40: 964-366.

GASSON, M.J. e F.L. DAVIES, 1980 b. Conjugal transfer of the drug resistance plasmid PAMB in the lactic streptococci. FEMS Microbiology Letters, 7: 51-53.

GASSON, M.J. e F.L. DAVIES, $1900 \mathrm{c}$. High - frequency conjuga tion associated with Streptococcus lactis donor cell aggre gation. Journal of Bacteriology, 143: 1260-1264.

GASSON, M.J. e F.L. DAVIES, 1984. The genetics of dairy lactic* -acid bacteria. In: DAVIES, F.L. e LAW, B.A., Eds. Aduances in the microbiology and biochemistay of Cheese and Fermented Milk. London and New York, Elsevier Appiied Science Publishers, p. 99-125:

GEIS, A., 1982. Transfection of protoplasts of Streptococcus lactis subsp. diacetylactis. FEMS Microbiology Lettors, 15: $19-122$ 
GEIS, A., J. SHING e M. TEUBER, 1983. Potential of lactic streptococci to produce bacteriocin. Applied and Environmental Nicrobiology, 45: 205-211.

GINGERAS, T.R. e J. BROOKS, 1983. Cloned restricticn modification system from Pseudomonas aeruginosa. Proceedings of the National Academy of Science, 80: 402-406.

GEORGHIOU, D., S.H. PHUA E E. TERZAGHI, 1981. Curing of a lySO genic strain of Streptococcus cremoris and characterization of the temperate bacteriophage. Journal of General Microbiologis, !22: 295-303.

GORDON, J.F. e N. SHAPTON, 1977. Characteristics and use of starters for the manufacture of yoghurt, cottage cheese, cultured buttermilk and other fermented foods. Jounnal of the Society of Dainy Technology, 30: 15-22.

GRAHAM, D.M., C.P. PARMELEE e F.E. NELSON, 1952. The carrier state of lactic streptococcus bacteriophages. Journal of Dairy Science, 35: 813-822.

GUDKOV, A.V., G.D. PERFIL'EV, L.S. MATEVOSYAN, V.M. DOKURIN e V.1. CHEPKOVA, 1980. Physiological and biochemical characte ristics of lactic acid bacteria present in cheese starters. Dairy Science Abstracts, $42: 46$.

GULSTROM, T.J., L.E. PEARCE, W.E. SANDINE e P.R. ELLIKER, 1979. Evaluation of commercial phage inhibitory media. Journal of Dairy Science, 62: 208-221. 
HAMMOND, L.A., 1976. Starters and microorganisms in cheesemaking. Food Technology, Australia, 28: 11-13.

HARGROVE, R.E., 1959. A simple method for eliminating and controlling bacteriophage in lactic starters. Journal of Dairy Science, 4 2: 906 .

HARGROVE, R.E., F.E. MCDONOUGH e R.P. TITTSLER, 1961. Phosphate heat treatment of milk to prevent bacteriophage prolifieration in lactic cultures. Journal of Dainy Science, 44 : $1799-1810$

HARRIGAN, W.F. e E. MCCANCE, 1976. Laboratory Methods in Food and Dairy Michobiology. London, Academic Press, 452 p.

HARR!S-WARWICK, R.M., Y. ELKANA, S.D. ERLICH e J. LEDERBERG, 1975. Eletrophoretic separation of Bacillus subtilis genes. Proceedings of the National Academy of Science, USA, 122: 2207$-22 i 1$.

HAYES, W., 1968. The genetics of bacteria and their viruses. New York, John Wiley E Sons, Inc.

HEAP, H.A. e A.W. JARVIS, 1980. A comparison of prolate and isometric headed lactic streptococcal bacteriophages. New zealand Journal of Dairy Science and Technology, 15:75-81.

HEAP, H.A. E R.C. LAWRENCE, 1976. The selection of starter strains for cheesomaking. New Zealand Journal of Dairy Science and Technodogy, 11: 16-20. 
HEAP, M.A. e R.C. LAWRENCE, 1981. Recent modifications to the New Zealand activity test for Cheddar cheese starters. New Zealand Journal of Dairy Science and Technology, 15: 91-94.

HEAP, H.A., G.K. LIMSOWTIN e R.C. LAWRENCE, 1978. Contribution of Streptococcus lactis strains in raw milk to phage infection in commercial cheese factories. New Zealand Journal of Dairy Science and Technology, 13: 16-22.

HENNING, D.R.W., W.E. SANDINE, P.R. ELLIKER e H. HAYS, 1965. Studies with a bacteriophage inhibitory medium. Jounnal of Food Technology, 28: $273-277$.

HENNING, D.R.W., C.H. BLACK, W.E. SANDINE e P.R. ELLIKER, 1968. Host-range studies of lactic streptococcal bacteriophages. Journal of Dairy Science, 51: 16-21.

HinterMani, G., H.M. FISCHER, R. CRAMERl e R. HUtTER, 1981. Simple procedure for distinguishing CCC, $O C$ and $L$ forms of plasmid DNA by agarose gel electrophoresis. Plasmid, 5: 371$-373$.

HUGGINS, A.R., 1984. Progress in dairy starter culture technology. Food Technology, 38: 41-50.

HUGGINS, A.R. e W.E. SANDINE, 1977. Incidence and properties of temperate bacteriophages induced from lactic streptococci. Applied and Environmental Microbiology, 33: 184-191. 
HUGGINS, A.R. e W.E. SANDINE, 1979. Differentiation of fast and slow milk - coaguiating isolates of lactic streptococci. Journal of Dairy Science, 622 (Suppl. 1): 70 .

HULL, R.R., 1977 a. Methods for monitoring bacteriophage in cheese factories. The Australian Journal of Dairy Technology, 32: $63-65$.

HULL, R.R., 1977 b. Control of bacteriophage in cheese factories. The Australian Journal of Dairy Technology, 32: 65-66.

HULL, R.R., 1978. Methods of monitoring for bacteriophage in cheese manufacture. In: Factory Derived Cheese Starters.

HULL, R.R., Ed. Proceedings of a meeting organized by The Dairy Research Laboratory Division of Food Research, CS!RO, and The Australian Dairy Corporation. Highett, Australia, $68 \mathrm{p}$

HULL, R.R., 1983. Factory - derived starter cultures for. the control of bacteriophage in cheese manufacture. Australian Journal of Daing Technology, Dec. 149-154.

HULL, R.R. e A.R. BROOKE, 1982. Bacteriophages more active against Cheddar cheese starters in untreated milk. The Australian Journal of Dairy Technology, 32: 143-146. 
HUNTER, G.J.E., 1943. Bacteriophages for Streptococcus cremoris. Phage development at various temperatures. Journal of Dairy Research, 13: 136-145.

HURST, A. e J.M. STUBBS, 1969. Electron microscopic study of membranes and walls of bacteria and changes occuring during growth initiation. Journal of Bacteriology, 97: 1465-1479.

INTERNATIONAL DAIRY FERMENTATION, 1980. Starters in manufacture of cheese. 2. Factors affecting the results of an activity test of mesophilic cheese starters. Bulletin IDF (129): $5-9$.

JARViS, A.W., 1977. The serological differentiation of lactic streptococcal bacteriophage. New Zealand Journal of Dairy Science and Technology, 12: 176-181.

JARVIS, A.W., 1978. Serological studies of a host range mutant of a lactic streptococcal bacteriophages. Applied and Environmental Microbiology, 36: 785-789.

JARVIS, A.W., 1981. The use of whey derived phage-resistant starter strains in New Zealand cheese plants. New Zealand Journal of Dairy Science and Technology, 16: 25-31.

JARVIS, A.W., 1982. Multiple lysogeny in lactic streptococci. XXIth International Dainy Congress, roscow, 1 : 314. 
JARVIS, A.W., 1984 a. Differentiation of lactic streptococcal phages into phage species by DNA-DNA homology. Applied and Environmental Microbiology, 47: 35-349.

JARVIS, A.W., 1984 b. DNA-DNA homology between lactic streptococci and their temperate acid lytic phages. Applied and Environmental Microbiology, 47: 1031-1038.

KEMPLER, G.M. e L.L. MCKAY, 1979. Genetic evidence for plasmid- linked lactose metabolism in Streptococcus lactis subsp. diacetylactis. Applied and Environmental Microbiology, 37 : $1041-1043$

KEMPLER, G.N. e L.L. MCKAY, 1981 . Biochemistry and genetics of citrate utilization in Streptococcus lactis subsp. diacetylactis. Journal of Dairy Science, 64: 1527-1539.

KEOGH, B.P.; 1972. A re-assesment of the starter rotation system. Australian Journal of Dairy Technology, 27: 86-87.

KEOGH, B.P., 1973. Adsorption, iatent period and burst size of phages of some strains of lactic streptococci. Journal of Dairy Research, 40: 303-209.

KEOGH, B.P., 1980. Appraisal of media and methods of assay of bacteriophages of lactic streptococci. Applied and Environmental Microbiologi, 40: 798-802. 
KEOGH, E.P. e P.D. SHIMMIN, 1969. An inducible antibacterial agent produced by a strain of Streptococcus cremoris. Journal of Dairy Research, 35: 87-93.

KEOGH, B.P. P P.D. SHIMMIN, 1974. Morphology of the bacteriophage of lactic streptococci. Applied Microbiology, 27: 411$-415$.

KEOGH, B.P. e E. PETTINGILL, 1983. Adsorption of bacteriophage éb 7 on Streptococcus cremoris EB 7. Applied and Environmental Microbiology, 45: 1946-1948.

KING, W.R., E.B. COLLINS e E.L. BARRETT, 1983. Frequencies of bacteriophage-resistant and show acid producing variants of Streptococcus cremoris. Applied and Environmental Microbio$\log y, 45: \quad i 481-1485$.

KLAENHAMMER, T.R., 1984. Interactions of bacteriophages with lactic streptococci. Advances in Applied Microbiology, 30: $1-29$.

KLAENHAMMER, T.R. e L.L. MickAy, 1976. Iso:ation and examination of transucing bacteriophage from Streptococcus lactis $c_{2}$. Journal of Dairy Science, 59: 396-404.

KLAENGAMMER, T.R., L.L. MCKAY e K.A. BALOWIN, 1978. Improved lysis of group $N$ streptococci for isolation and rapid characterization of piasmia DNA. Applied and Environmental Microbiology, 35: 592-600. 
KLlMOUSKI!, 1.1., V.I. ZVYAGINTSEN, A.V. GUOKOV E Z.P. MEDVEDE VA, 1973. Selection of strains in the formulation of starters. Dairy Science Abstracts, 35: 135.

KOK, J., J.M.B.M. van der VOSSEN e G. VENEYAA, 1984. Construction of plasmid cioning vectors for lactic streptococci which also replicate in Bacillus subtilis and Escherichia coli. Applied and Environmental Microbiology, 48: 726-731.

KONDO, J.K. e L.L. MckAY, 1982. Transformation of Streptococcus lactis protoplasts by plasmid DNA. Applied and Environmental Microbiology, 43: $1213-1215$.

KONDO, J.K. e L.L. MCKAY, 1983. Parameters affecting plasmid transformation of Streptococcus lactis protoplasts. Journal of Dairy Science, Suppl. 1, 65: 56.

KONOO, J.K. e L.L. MCKAY, 1984. Plasmid transformation of Strep tococcus lactis protoplasts: optimization and use in molecuiar cloning. Applied and Environmental Microbiology, 48: $252-259$.

KOSIKOWSk!, F., 1977. Cheese and fermented milk foods. 2nd. ed. Ann Arbor, Edwards Bros, inc.

KOZAK, W., M. RAJCHERT-TRZPIL, J. ZADJEL E W.P. DOBRZANSKI, 1973. Lysogeny in lactic streptococci producing and not pro ducing nisin. Applied Microbiology, 25: 305-308. 
KRETSCHMER, P.J., A.C.Y. CHANG E S. COHEN, 1975. Indirect selection of bacterial plasmids lacking identifiable phenotypic properties. Jounnal of Bacteriology, 124: 225-231.

KRÜGER, D.H., S. HANSEN E C. SCHROEDER, 1980. HOst-dependent modification of bacterial virus $T 3$ affecting its adsorption ability. Virology, 102: $444-446$.

KRÜGER, O.H. e T.A. BICKLE, 1983. Eacteriophage survival: multiple mechanisms for avoiding the deoxyrinonucleic acid restriction systems of their hosts. Microbiological Reviews, 47: $345-360$.

KUHL, S.A., L.D. LARSEN e L.L. McKAy, 197.9. Plasmid profiles of lactose - negative and proteinase - deficient mutants of Streptococcus lactis CIO, ML3 and Mi8. Applied and Environmental Nicrobiologij, 37: 1193-1195.

LANGelLA, P., 1982. Amélioralion des techniques de detérmination des plasmides de streptocoques lactiques mésophiles. Marseille, Université d'Aix-Marseille 11 , Faculté de Pharmacie, 25 p. (D.E.A. de Microbiologie).

LARSEN, L.D. e L.L. MCKAY, 1978. Isolation and characterization of plasmid DNA in Streptococcus cremoris. Applied and Environmental Microbiology, 36: 944-952. 
LAW, B.A. e J. KOLSTAD, 1983. Proteolytic systems in lactic acid bacteria. Antonie van Leeuwenhoek, 49: 225-245.

LAWRENCE, R.C., 1978. Action of bacteriophage on lactic acid bacteria: consequence and protection. New Zealand Journal of Dairy Science and Technology, 13: 129-136.

LAWRENCE, R.C. e L.E. PEARCE, 1972. Cheese starters under contro1. Dairy Industry, : 73-78.

LAWRENCE, R.C. A T.D. THOMAS, 1979. The fermentation of milk by lactic acid bacteria. 29th Symposium of the society for General Microbiology, Cambridge University Press, 187 p.

LAWRENCE, R.C., T.D. THOMAS e B.E. TERZAGHI, 1976. Reviews of the progress of dairy science: cheese starters. Journal of Dairy Research, 43: 141-193.

LAWRENCE, R.C., H.A. HEAP, G. LIMSOWTIN E A.W. JARVIS, 1978. Cheddar cheese starters: Current knowledge and practices of phage characteristics and strain selection. Journal of Dairy Science, 61: 1181-1191.

LeBLANC, D.J.R., R.J. HAWLEY, L.N. LEE e E.J. St. MARTIN, 1978. "Conjugal" transfer of plasmid DNA among oral streptococci. Proceedings of the National Academy of Science USA, 75 : $3484-3487$ 
LEBLANC, D.J., V.L. CROW, L.N. LEE e C.F. GARON, 1979. Influen ce of the lactose plasmid on the metabolismoi galactose by Sireptococcus lactis. Journal of Bacteriology, 137: 878$-884$

LeBLANC, D.J., V.L. CROW e L.N. LEE, 1980. Plasmid mediated carbohydrate catabolic enzymes among strains of Streptococcus lactis. In: STUTTARD, C. e K.R. ROZEE, Eds. Plasmids and transposons. Envirovmental efjects and maintenance mechanisms. New York, Academic Press, inc., p. 31-41.

LeBLANC, D.J. e L.N. LEE, 1984. Physical and generic analyses of streptococcal plasmid $P A M B l$ and cloning of its replication region. Journal of Bacteriology, 157: 445-453.

LEGG, W.M., 1973. The selection and maintenance of starters for non cheddar cheese varieties. Dainy Science Abstracts, 35: 54

LEMBKE, A., F. WASSERFALL e G. ENGEL, 1972. Stüdien über Käsereifung. 3. Phagentypisierung der für die Käsehertellung selektivierten hochwertigen Reinkulturen. Kiel. Milchwirtsch. Forschungsber, 24:49-421.

LEMBKE, J., V. KRUSCH, A. LOMPE e M. TEUBER, 1980. Isolation and uitrastructure of bacteriophages of group $N$ (lactic) streptococci. Zenthalblatt für Bakteriologie Parasitenkdende Infektionskrankheiten und Higiene. Originalie Reihe $C$, $1: 79-91$ 
LEMBKE, j. e M. TEUBER, 1981. Setoryping of morphologically identical bacteriophage of lactic streptococci by immunoelectron microscope. Milchwissenchaft, 36: 10-12.

LEMBKE, J. a M. TEUBER, 1982. XXI International Dairy Congress, Moscow, 1 (2): 334. Apud: DAVIES, F.L. e B.A. LAW, Eds. Advances in the Microbiology and Biochemistry of Cheese and Fermented Milk, London, New York, Elsevier Applied Science publishers, p. 99-126.

LIMSOWIN, G.K.Y. e B.E. TERZAGH!, 1976. Phage resistant mutants: their selection and. use in cheese factories. New Zealand Journal of Dairy Science and Technology, 11: 251-256.

LIMSOWTIN, G.K.Y. e B.E. TERZAGHI, 1977. Characterization of bacterial isolates from a phage - carrying culture of $S$. cremoris. New Zealand Jounnal of Dairy Science and Technolo $9 y, \quad 12: 22-28$.

LIMSONTIN, G.K.Y., H.A. HEAP e R.C. LAWRENCE, 1977. A mUItiple starter concept for cheesemaking. New Zealand journal of Dairy Science and Technology, 12: 101-106.

LIMSOWTIN, G.K.Y., H.A. HEAP e R.C. LAWRENCE, 1978. Heterogeneity among strains of lactic streptococci. New Zealand Journal of Dainy Science and Technology, 13: 1-2. 
LOOF, M., J. LEMBKE e M. TEUBER, 1983. Characterization of the genome of the Streptococcus lactis subsp. diacetylactis Dacteriophage p0o 8 wide - spread in german cheese factories. Systemaicic and Applied Microbiology, 4: it3-ti23.

LOWRIE, R.J., 1974. Lysogenic strains of group N lactic streptococci. Applied Michobiology, 27: 210-217.

LOWRIE, R.J. e L.E. PEARCE, 1971 a. The plating efficiency of bacteriophages of lactic streptococci. New Zealand Jounnal of Dairy Science and Technology, 6: 155-171.

LOWRIE, R.J. e L.E. PEARCE, 1971 b. Üse of indicador strains for the assay of bacteriophages of lactic streptococci. New Zealand Journal of Dairy Science and Technology, 6: 192 .

LURIA, S.E., 1953. Host-induced modification o: viruses. Cold Spring Harbor Symposia on quantitative Biology, 18: 237$-244$

MACRINA, F.L., P.H. WOOD e K.R. JONES, 1980. Genetic transformation of Streptococcus sanguis (challis) with cryptic plasmids from Streptococcus berus. Infection and Immunity, 28: $692-699$.

MACRINA, F.L., C.L. KEELER, JH., K.R. JONES P P.H. WOOD, 1980. Molecular characterization of unique deletion mutants of the streptococcal plasmid pAMBi. Plasmid, 4 : 8-16. 
MACRINA, F.L., J.A. TOB!AN, K.R. JONES e R.P. EVANS, 1982. MOlecular cioning in the streptococci. In: Hollaender, A., R. DEMOSS, S. KAPLAN, J. KONISKY, D. SAVAGE e R. WOLFE, EdS. Genetic engineering of microorganisms for chemicals. New York, Plenum, p. 195-210.

MACRINA, F.L., R.P. EVANS, J.A. TOBIAN, D.L. HARTLEY, D.B. CLEOWELL e K.R. JONES, 1983. Novel shuttle plasmid vehicles for Escherichia - Streptococcus transgeneric cloning. Gene, 25: $145-150$.

MALCOM, A.D.B., 1981. The use of restriction enzymes in genetic engineering. In: WILLIAMSON, R., Ed. Cenetic Enginee ring 2. New York, Academic Press, p. 130-167.

MANIATIS, T., E.F. TRITSCH e J. SAMBROOK, 1982. Molecular cloning. A laboratory manual. Cold Spring Harbor Laboratory. New York, Cold Spring Harbor, $545 \mathrm{p}$.

MARCOS, A., M.A. StEBAN, J. espejo, P. MARTINEZ e M.t. MUÑOZ, 1977. "Screening" de las cepas proteoliticas del queso tipo Manchego y accion de las proteasas de las suspensiones de celulas sobre la $\alpha_{s}$ e $\beta$-caseina. Archivos de Zootecnia, 26: $189-199$.

MCCLELLAND, M., 1981. The effect of sequence specific ONA methytation on restriction endonuclease cleavage. Nucleic Acid Research, 9: 5859-5866. 
MCKAY, L.L., 1982. Regulation of lactose metabolism in dairy streptococci. In: DAVIES, R., Ed. Developments in food microbiology-1. Essex, England, Appiied Science Publishers Ltd. p. 153-182.

MickAY, L.L., 1983. Functional properties of plasmidis in lactic streptococci. Antonie van Leewenhoek, 49: 259-274.

McKAY, L.L., 1984. Genetic modifications of lactic acid bacteria: plasmid directed functions and development of gene transfer systems. In: S.F.M., Ed. Genétique des micro-organismes industhiels. 9ème colloque de microbiologie industrielle et biotechnologie. Paris, p. 141-154.

MCKAY, L.L. e K.A. BALDWIN, 1973. Induction of prophage in Streptococcus lactis $C_{2}$ by uitraviolet irradiation. Applied Nicrobiology, 25: $682-684$.

MCKAY, L.L. e K.A. BALDWIN, 1974. Simultaneous loss of proteinase and lactose - utilizing enzyme activities in Streptococcus lactis and reserval of loss by transduction. Applied Nicrobiology, 28: 342-346.

MCKAY, L.L. e K.A. BALDWIN, 1975. Plasmid distribution and evi dence for a proteinase plasmid in streptococcus lactis. $c_{2}$. Applied Nicrobiology, 29: 546-548. 
NickAY, L.L. e K.A. BALOWh, 1984. Conjugative 40 - megadalton plasmid in streptococcus lactis subsp. diacetylactis DRC3 is associated with resistance to nisin and bacteriophage. Appliea and Environmental Niccobiology, 47: 68-74.

MCKAY, L.L., K.A. BALOWIN E 3.D. EFSTATHIOU, 1976. TranSdUCtional evidence for plasmid linkage of lactose metabolismin Streptococcus lactis $C_{2}$. Applied and Environmental Microbio $\log y, 32: 45-57$.

MCKAY, L.L., K.A. BALDWIin e P.J. WALSH, 1980. Conjugal transfer of genetic information in group iN streptococci. Applied and Environmental Microbiology, 4:0:84-91.

MESELSON, M., Y. ROBERT E J. HEYWOOD, 1972. Restriction and modification of DNA. Annual Review of Biochemistrly, 41: 447$-466$

MEYERS, J.A., D. SANCHEZ, L.P. ELWELL e S. FALKOW, 1976. Simple agarose gel eletrophoretic method for the identification and characterization of plasmid deoxyribonucleic acid. Journal of Bacteniology, 127: 1529-1537.

MOLSKNESS, T.A., W.E. SANOINE E L.R. BROWN, 1974. Characteriza

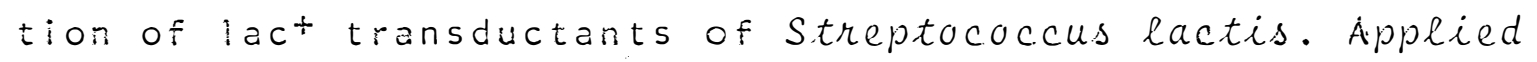
Microbiology, 28: $753-758$. 
MULLAN, W.H.A., C. DALY e P.F. FOX, 1983. Effect of cheesemaking temperatures on the interactions of lactic streptococci and their phages. Journal of Dairy Research, 48: $465-471$.

MURRAY, K. e N.E. MURRAY, i975. Phage Lamdba receptor chromosome for DNA fragments made with restriction endonuclease III of Haemophilus influenzae and restriction endonuclease I of E. coli. Journal of Molecular Biology, 98: 551-564.

NICHOLS, A.A. e M. HOYLE, 1949. Bacteriophages in typing lactic streptococci. Jounnal of Dairy Research, 16: 167-208.

NoV!CK, R.P., 1969. Extrachromosomal inheritance in bacteria. Bacteriology Reviews, 35: 210-263.

NOVICK, R.P., C. SANCHEZ-RIVAS, A. GRUSS E I. EDELMAN, 1980. involvement of the cell envelop in plasmid maintenance: plas mid curing during the regeneration of protoplasts. Plasmid, 3: $348-358$.

NYIENDO, J., R.J. SEIDLER, W.E. SANDINE e P.R. ELLIKER, 1974. Preparation and storage of high-titer lactic Streptococcus. bacieriophages. Applied Microbiology, 27: 72-77.

OKAMOTO, T., Y. FUJITA e R. IRIE, 1983. Fusion of protoplasts of Streptococcus lactis. Agricultural and Biological Chemistriy, 47: $2675-2676$. 
ORAM, J.0., 1971. Isolation and properties of a phage receptor substance from the plasma membrane of Streptococcus iactis ML3. Journal of General Virology, i3: 59-71.

ORAM, J.D. e B. REITER, 1968. The adsorption of phage to group $N$ streptococci: the specificity of adsorption and the location of phage receptor substances in cell-wall and plasma - membrane fractions. Journal of General Virology, 3: 103$-119$.

ORBERG, P.K. e W.E. SANDINE, 1984. Microscale method for rapid isolation of covalently closed circular plasmid DNA from group $N$ streptococci. Applied and Environmental Microbio$\log 4,47: 677-680$.

OTTO, R., M. de VOS WILLEM e J. GAVRIELI, 1982. Plasmid DNA in Streptococcus cremoris $\mathrm{Wg} 2$ : influence of pH on selection in chemostats of a variant lacking a protease plasmid. Applied and Environmental Microbiology, 43: 1272-1277.

OVERBy, A.J., 1976. Starter problems. Danish Industrial world, 1: $15-17$.

PARADA, J.L., M.I. LA V:A e A.J. SOLARI, 1984. Isolation of Streptococcus lactis bacteriophages and their interaction with the host cell. Applied and Environmental Microbiology, 47: $825-328$. 
PARK, C. e L.L. MeKAY, 1975. Induction of prophage in lactic streptococci isolated from commercial dalry starter cultures. Journal of Milk Technology, 38: 594-597.

PARK, Y.H, e L.L. McKAY, 1982. Distinct galactoses phosphoenol pyruvate - dependent phosphotransferase system in Streptococcus lactis. Journal of Bacteriology, 149: 420-425.

PARMELLEE, C.E., P.H. CARR e F.E. NELSON, 1949. Electron microscope studies of bacteriophage active against stheptococcus lactis. Journal of Bacteriology, 57: 391-397.

PEARCE, L.E., 1969. Activity test for cheese starter cultures. New Zealand Journal of Dairy Science and Tecnhology, 4: 246-247 .

PEARCE, L.E., 1978. The effect of host - controlled modification on the replication rate of a lactic streptococcal bacteriophage. New Zealand Journal of Dairy Science and Technology, 13: 166-171.

PEARCE, L.E., G.K.y. LIMSOWTIN e A.M. CRAWFORD, 1970. Bacteriophage multiplication characteristics in Cheddar cheesemaking. New Zealand Journal of Dairy Science and Technology, 5: 145$-150$.

PEARCE, L.E., N.A. SKIPPER e B.J. JARVIS, 1974. Protel ase activity in s?ow lactic acid - producing varionts of Streptococcus lactis. Applied Microbiology, 27: 933-937. 
PECHMANN, H. e M. TEUZER, 1980. Plasmid pattern of group $N$ (lactic) streptococci. Zenthalblatt fïr Bakteriologie, 10, $1: 133-136$

PORTNOY, D.A., S.L. MOSELEY E S. FALKOW, 1981. Characterization of plasmids and plasmid associated determinants of Versinia enterocolitica pathogenesis. Infection and Immunity, 31: 775-782.

PORUBCAN, R.S. e R.L. SELLARS, 1979. Lactic starter cultures concentrates. In: PEPPLER, H.J. e D. PERLMAN, Eds., Microbial Technology, Vol. 1. Microbial Processes. London, UK, Academic Press, Inc:, 2nd ed., p. 59-92.

POTTER, N.N. 1970. Host - induced changes in lactic streptococal bacteriophages. Journal of Dainy Science, 53: 1358-1362.

POTTER, N.N. e F.E. NELSON, 1952. Effects of calcium on proliferation of lactic Streptococcus bacteriophage. 11. Studies of optimum concentrations in a partially defined medium. Journal of Bacteriology, 64: 113-119.

POTTER, N.N. e F.E. NELSON, 1953. Role of calcium and related ions in proliferation of lactic streptococcus bacteriophage. Iowa Agricuetural Experiment Station, Ames, lowa, 66 : 508$-516$ 
REINBOLD, G.W., M.S. REDDY E E.G. HAMNOND, 1982. Uitrastructures cf bacteriophages active against Streptococcus thermophilus, Lactobacillus bulgaricus, Lactobacillus lactis and Lactobacillus helveticus. Journal of Food Protection, 45: $119-124$

REITER, B., 1949. Lysogenic strains of lactic streptococci. Na iure, London, 164: 667-668.

REITER, B., 1956. Apud: SANDINE, W.E., 1980. Lactic starter cul ture technology. Pfizer Cheese Monographs, Vol. V!, New York, Pfizer inc., $38 \mathrm{p}$.

REITER, B., 1973. Some thoughts on cheese starters. Journal of the Society of Dairy Technology, 26: 3-21.

REITER, B. e A. MDLLER-MADSEN, 1963. Reviews of the progress of dairy science. Section 8 . Cheese and Dairy Starters. Journal of Dairy Research, 30: 419-455.

REITER, B. e M. KIR!KOVA, 1976. The isolation of a lysogenic strains from a multiple strain starter culture. Journal of the Society of Dairy Technology, 29: 221-225.

Reyrolle, J., M.-C. CHOPIN, F. Letellier e G. NOVel, 1982. Lysogenic strains of lactic acid streptococci and lytic spectra of their temperate bacteriophages. Applied and Environmental Microbiology, 43: 349-356. 
RICHARDSON, G.H., i984. Proteinase negative cultures for cheesenaking. Cultured Dairy production journal, 19: 6-9.

RICHARDSON, G.H., C.T. CHENG e R. YOUNG, 1976. Lactic bulk cuI ture system utilizing whey - based bacteriophage inhibitory medium and pH control. 1. Applicability to American style cheese. Journal of Dairy Science, 60: 378-386.

RICHARDSON, G.H., G.L. HONG e C.A. ERNSTROM, 1980. Defined sin gle strains of lactic streptococci in bulk culture for Cheddar and Monterey cheese manufacture. Journal of Dairy Science, 63: 1981-1986.

RICHARDSON, G.H., C.A. ERNSTROM e C. DALY, 1983. Proteinase ne gative variants of Streptococcus cremoris for cheese starters. Journal of Dairy Science, 66: 2278-2286.

SANDERS, M.E. e T.R. KLAENHAMMER, 1980. Restriction and modifi cation in group $N$ streptococci: effect of heat on development of modified lytic bacteriophage. Applied and Environmental Microbiology, 40: 500-506.

SANDERS, M.E. e T.R. KLAENHAMER, 1981. Evidence for plasmid linkage of restriction and modification in Streptococcus cremoris $\mathrm{kH}$. Applied and Environmental Microbiology, 42 : $944-950$ 
SANOERS, M.E. e T.R. KLAENHAMMER, 1983. Characterization of phage-sensitive mutants from a phage-insensitive strain of Streptococcus lactis: evidence for a plasmid determinant that prevents phage adsorption. Applied and Environmental Microbiology, 46: 1125-1133.

SANDERS, M.E. e T.R. KLAENHAMMER, 1984. Phage resistance in a phage-insensitive strain of Streptococcus lactis: temperature-dependent phage development and host-controlled phage replication. Applied and Environmental Microbiology, 47: $979-985$.

SANDINE, W.E., 1977. New techniques in handling lactic cultures to enhance their performance. Journal of Dairy Science, 60: $822-827$.

SANDINE, W.E., 1980. Lactic starter culture technology. Pfizer Cheese Monographs. Vol. V!. New York, Pfizer inc. 38 p.

SANOINE, W.E. C J.W. AYRES, 1981. Method and starter compositions for the growth of acid producing bacteria and bacterial compositions produced thereby. US Pat. 4,282,255.

SCHERWITZ, K.M., K.A. BALDWIN e L.L. MCKAY, 1983. Plasmid linkage of a bacteriocin-like substance in Streptococcus lactis subsp. diacetylactis strain VML: transferability to Streptococcus lactis. Applied and Environmental Microbiology, 45: $1506-1512$. 
SHARPE, M.E., 1979. Lactic acid bacteria in the dairy industry. Jounnal of the Society of Daing Technology, 32: 9-17.

SHARPE, M.E. E T.F. FRYER, 1966. Identification of the lactic acid bacteria. In: GIBBS, B.M., 1966. Identification methods for microbiologists. London, Academic Press, $145 \mathrm{p}$.

SIMON, 0., 1984. Transformation de protoplastes de streptocoques lactiques par de l'ADN plasmidique. Université de Rennes 1, 2l p. (DEA de Biologie Cellulaise et Moleculaire).

SIMON, D., A. ROUAUIT e M.-C. CHOPIN, 1985. Protoplast transformation of group $N$ streptococci with cryptic plasmids. FEMS Michobiologid Letters, 26: 239-241.

SiNHA, R.P., 1980. Alteration of host specificity to lytic bac teriophages in Streptococcus cremoris. Applied and Environmental Microbiology, 40: $326-332$.

SMILEY, M.B., 1980. Bacterial genetics, molecular biology and dairy cultures. Nestle Research News. p. 39-53.

Sozzl, T., 1972. Etude sur la préparation de ferments lactiques très actifs. Le Lait, 52: 454-465.

Sozz!, T., 1973. The preparation of very active lactic cultures. Le Lait, 52: 454-465. 
SOZZ1, T. e R. MARET, 1975. Isolement et quelques caractéristi ques des baciériophages de $S$. thermophilus et de L. helveticus de ferments d'Emmental. Le Lait, 55: 269-288.

SOZZI, T., R. MARET e J.M. POULIN, 1976. Study of plating efficiency of bacteriophages of thermophilic lactic acid bacteria on different media. Applied and Environmental Michobiology, 32: 13i-137.

SOZZI, T., J.M. POULIN e R. MARET, 1978. Effect of incubation temperature on the development of lactic acid bacteria and their phages. Journal of Dairy Research, 45: 259-265.

SOZZ!, T., H. BAUER, R. MARET e E. DENTAN, 1980. Some characteristic of fine phages capable of lysing a strain of Streptococcus lactis. Milchwissenchaft, 35: 17-20.

SPECK, M.L., 1982. Starter culture growth and action in milk. Journal of Dairy Science, 45: 1281-1286.

St. MARTIN, E.J., L.N. LEE e D.J. Le BLANC, 1982. Genetic analysis of carbohydrate metabolism in streptococci. In: SCHLESSINGER, D., Ed. Microbiology. Washington, D.C., American Society for Microbiology, p. 232-233.

STADHOUDERS, J., 1974. Dairy starter cultures. Milchwissenschaft, 29: $329-337$. 
STADHOUDERS, J., 1975. Microbes in milk acid dairy products. An ecological approach. Netherlands Milk and Dairy Journal, 29: $104-126$.

STADHOUDERS, 3. e F. HASSING, 1972. A standardized method of determining the activity of cheese starters. Voedingsmiddelentechnologie, 3: 190-:93.

SWARTLING, P.F., 1951. Biochemical and serological properties of some citric acid fermenting streptococci from milk and dairy products. Journal of Dairy Research, 13: 256-267.

TERZAGHI, B.E., 1976. Morphologies and host sensivities of lactic streptococcal phages from cheese factories. New Zealand Journal of Dairij Science and Technology, 11: 155-163.

TERZAGHI, B.E. O W.R. SANDINE, 1975. Improved medium for lactic streptococci and their bacteriophages. Applied Microbio $\log y, 29: 807-813$.

TERZAGHI, E.A. e B.E. TERZAGHi, 1978. Effect of lactose concen tration on the efficiency of plating of bacteriophages on Streptococcus cremoris. Applied and Environmental Microbio$\log y$, 35: $471-478$.

TERZAGHI, B.E. e W.E. SANDINE, 1981. Bacteriophage production following exposure of iactic streptococci to ultraviolet ra diation. Journal oś General Microbiology, 122: 305-311. 
TEUeER, M. e j. LEVEKE, 1982. In: Microbiology-1982. SCHLESSlNGER, D., Ed. Washington, D.C., American Society for Microbiology. Apud: DAVIES, F.L. e B.A. LAN, 1984. Advances in the Microbiology and Biochemistry of Cheese and Fermented Milk. London, New York, Elsevier Applied Science Publishers, p. $99-125$.

TEUBER, M. e J. LEMBKE, 1983. The bacteriophage of lactic acid bacteria with emphasis on genetic aspects of group $N$ streptococci. Antonie van Leeuwerhoek, 49: 283-295.

THOMAS, T.D. e R.J. LOWR!E, 1975. Starters and bacteriophages in lactic casein manufacture. 1. Mixed strain starters. Jour nal ot Milk and Food Technolosy, 38: 275-273.

THUNELL, R.K., W.E. SANDANE e F.W. BODYFELT, 1981. Phage-sensi tive, multiple-strain starter approach to Cheddar cheese ma king. Journal of Dairy Science, 2270-2277.

TIKHONENKO, A.S., 1970. Wetrastructure of bacterial viruses. New York, Plenum Publishing Corp., $145 \mathrm{p}$.

TSANEVA, K.P., 1976. Electron microscopy of virulent phages for Streptococcus lactis. Applied and Environmental Michobiology, 31: $590-601$.

TUNERMAN, L. e B.H. WEBB, 1965. Coagulation of milk and protein denaturation. In: WEgB, 8.h. e A.H. JoHnson. Fundamentals of Dairy Chemistry. Westport, The AVI Publishing Company, inc. p. 506-672. 
YANG, N.L. e W.E. SANDINE, 1979. Acid-producing activity of iyophilized lactic streptococcal cheese starter concentrates. Journal of Dairy Science, 62: 908-915.

YU, R.S.-T., T.V. HUNG e A.A. AZAD, 1982. Rapid screening of highly purified plasmids in lactic streptococci. The Australian Journal of Dairy Technology, 37: 99-103.

YU, R.S.-T., T.V. HUNG e A.A. AZAD, 1983. P! ssmid complement and sequence homology of some technological strains of lac tic streptococci. The Australian Journal of Dainy Technology, 38: 104-109.

YUAN, R., 1981. Structure and mechanism of multifunctional res triction endonucieases. Annual Review of Biochemistry, En: $285-315$.

WALSH, P.M. e L.L. MckAY, 1981. Recombinant piasmid associated with cell aggregation and high-frequency conjugation of Streptococcus lactis ML 3. Journal of Bacteriology, 146 : $937-944$.

WATANABE, K. e S. TAKESUE, 1972. The requirement for calcium in infection with Lactobacillus phage. Journal of Caneral virology, 17: 19-30.

WHTEHEAD, H.R., 1953. Bacteriophage in cheese manufacture. Bac teriological Reviews, 17: 109-123. 
WHITEHEAD, H.R. e G.A. COX, 1935. The occurrence of bacteriophage in cultures of lactic streptococci. New Zealand Journal of Dairy Science and Technology, 16: 319-320.

WHITEHEAD, H.R. e G.A. COX, 1936. Bacteriophage phenomena in cultures of lactic streptococci. Journal of Dairy Research, 7: $55-62$.

WIGLEY, R.C., 1980. Advances in technology of bulk starter pro duction and cheesemaking. Journal of the Societij of Dairy Technology, 33: $24-30$.

WILKOWSKE, H.H., F.E. NELSON P C.E. PARMELEE, 1954. Serologica! classification of bacteriophages active against lactic strep tococci. Applied Microbiology, 22: 243-249.

WRIGHT, S.L. e G.H. RICHAROSON, 1982. Optimization of whey-based or nonfat dry milk-based media for production of pH con trolled bulk lacic cultures. Journal of Dairy Science, 65: $1882-1894$

ZEHREN, V.L. e H.R. WHITEHEAD, 1954. Growth characteristics of streptococcal phages in relation to cheese manufacture. Jour. nal of Dairy Science, 37: 209-219.

ZOTTOLA, E.A. e E.H. MARTH, 1966. Dry-blended phosphate-treated mik media for inhibition of bacteriophages active against iactic streprococci. Journal of Dainy Science, 49: $1343-1349$ 